\title{
PROPOSTA DE UMA INFRA-ESTRUTURA JURÍDICA PARA ORGANIZAÇÕES E EMPRESAS VIRTUAIS
}

Terencio Augusto Mariottini de Oliveira

Dissertação apresentada à Escola de Engenharia de São Carlos da Universidade de São Paulo, como parte dos requisitos para obtenção do título de Mestre em Engenharia de Produção

ORIENTADOR: Prof. Dr. Carlos Frederico Bremer

São Carlos

2000 
Aos meus pais e aos meus filhos, causa e efeito, verdadeiros valores da minha existência 
Ao Professor Carlos Frederico Bremer, pelo empenho, paciência e confiança depositados durante a orientação deste trabalho.

A todos os colegas, professores e funcionários do NUMA e da VIRTEC, pelo efetivo apoio e colaboração. 


\section{SUMÁRIO}

LISTA DE FIGURAS

LISTA DE ABREVIATURAS ………...................................................................................................................VII

RESUMO ........................................................................................................................................................................... VIII



1. INTRODUÇ̃̃

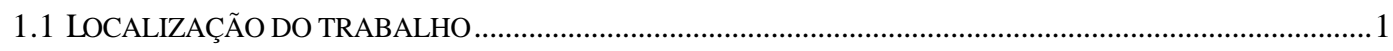

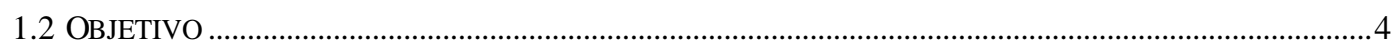

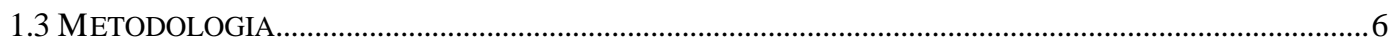

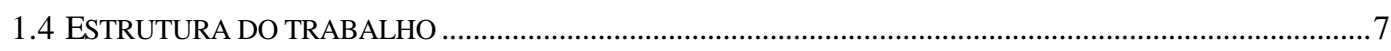



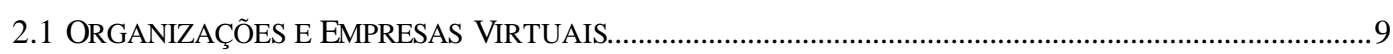

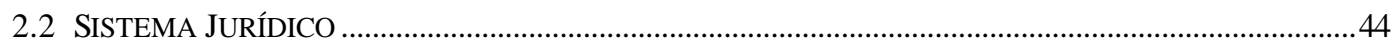

\section{ASPECTOS JURÍDICOS DAS ORGANIZAÇÕES E EMPRESAS VIRTUAIS DE}

INTERESSE PARA A TEORIA GERAL DA ADMINISTRAÇÃO......................................................... 73

3.1 UMA ABORDAGEM NECESSARIAMENTE SISTÊMICA …………………………………………….....73

3.2 INSUFICIÊNCIA DAS NORMAS ÉTICAS PARA SUPORTAR OS PROCESSO DE FORMAÇÃO DAS E.V.....75

3.3 A PERSPECTIVA DO EMPREENDEDOR E SUA FORMA DE VINCULAÇÃO …………………………......78

3.4 O PAPEL E A FEIÇÃO DO CONTRATO DIANTE DA NOVA ESTRUTURA DE COMUNICAÇÃO ..................82

4. PROPOSTA DE UMA INFRA-ESTRUTURA JURÍDICA APLICÁVEL A EMPRESAS

VIRTUAIS NO BRASIL ................................................................................................................................................................. 88

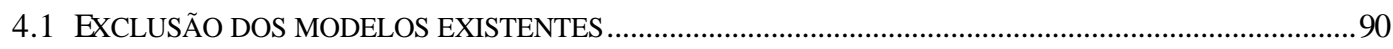

4.2 PRÓS E CONTRAS DA PERSONIFICAÇÃO ………………………………………………………...95

4.3 MODELO MAIS ADEQUADO DE PERSONALIDADE...........................................................................98

4.4 ENFRENTAMENTO DO TEMA NO NÍVEL TEÓRICO EM OUTROS PAÍSES ...............................................99

4.5 O CLUSTER COMO PRINCIPAL PLATAFORMA JURÍDICA....................................................................104

4.6 CLÁUSULAS QUE COMPORTEM A CONSOLIDAÇÃO DO CLUSTER BEM COMO GARANTAM AGILIDADE E SEGURANÇA AOS PROCESSOS DE FORMAÇÃO DAS EMPRESAS VIRTUAIS.. . .107

4.7 Os CONTRATOS DE EV - MUlTiPLICIDAdE DE MODELOS E FinALIDADES - COMÉRCiO E ELETRÔNICO E A LEI UNIFORME UNCITRAL 
5. APLICAÇÃO DA INFR A-ESTRUTURA PROPOSTA À UMA ORGANIZAÇÀO

VIRTUAL EM FORMAÇÃO - VIRTEC.......................................................................................................................141

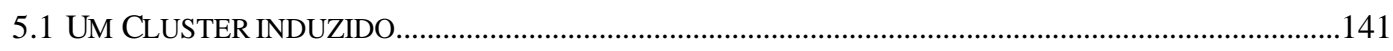

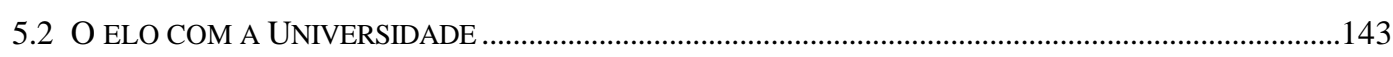

5.3 IDENTIFICAÇÃO DE COMPETÊNCIAS E DESENVOLVIMENTO DE PRODUTOS.......................................144

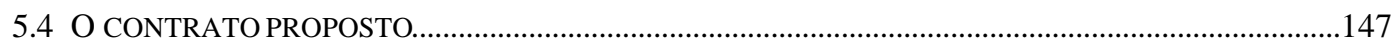

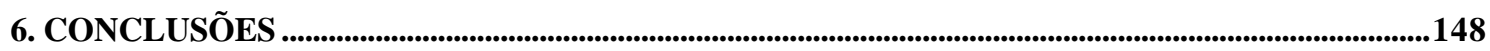

7. REFERÊNCIAS BIBLIOGRÁFICAS ...................................................................................................154

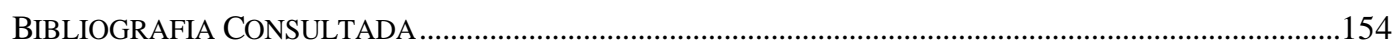

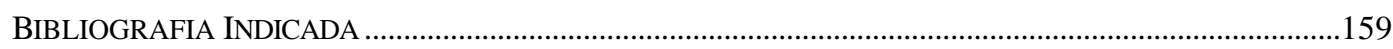

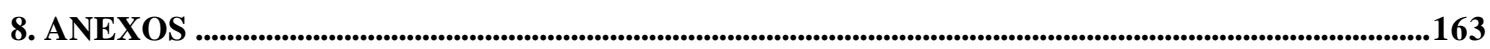




\section{LISTA DE FIGURAS}

Figura 1 - Perspectivas do Desenvolvimento Organizacional.........................................14

Figura 2- Modelo AVE (Agile Virtual Enterprise) ...........................................................16

Figura 3- Ciclo de vida para Empresas Virtuais ................................................................18

Figura 4- A caracterização do Broker na formação de Empresas Virtuais ...........................20

Figura 5- Plataforma de uma Organização Virtual.........................................................22

Figura 6- Culturas fundamentais em Organizações Virtuais .............................................24

Figura 7 - Barreiras à Cooperação entre Empresas …..................................................28

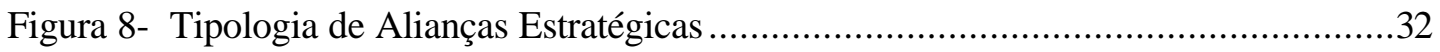

Figura 9 - Relação entre contrato de OV e contrato de EV ............................................. 106

Figura 10 - O papel da empresa líder ................................................................. 110

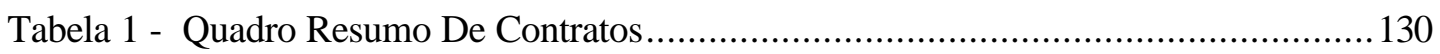




\section{LISTA DE ABREVIATURAS}

\begin{tabular}{|c|c|}
\hline AAMRC & - Agile Aerospace Manufacturing Research Center \\
\hline AMEF & - Agile Manufacturing Enterprise Forum \\
\hline APAE & - Associação de Pais e Amigos dos Excepcionais \\
\hline ARGE & - Arbeit Gruppe Erbauer \\
\hline AVE & - Agile Virtual Enterprise \\
\hline CADE & - Conselho Administrativo de Defesa Econômica \\
\hline $\mathrm{CC}$ & - Código Civil \\
\hline $\mathrm{CCo}$ & - Código Comercial \\
\hline $\mathrm{CDC}$ & - Código de Defesa do Consumidor \\
\hline $\mathrm{CPC}$ & - Código de Processo Civil \\
\hline DARPA & - Defense Advanced Research Projects Agency \\
\hline EV & - Empresa Virtual \\
\hline FAPESP & - Fundação de Amparo à Pesquisa do Estado de São Paulo \\
\hline GVI & - Grupo Virtual de Indústrias \\
\hline INTERNET & - Rede Mundial de Computadores \\
\hline ISO & - International Organization of Standardization \\
\hline NUMA & - Núcleo de Manufatura Avançada \\
\hline ONU & - Organização das Nações Unidas \\
\hline $\mathrm{OV}$ & - Organização Virtual \\
\hline SDE & - Secretaria de Direito Econômico do Ministério da Justiça \\
\hline TQM & - Total Quality Management \\
\hline $\mathrm{UE}$ & - União Européia \\
\hline UNCITRAL & - United Nations Commission on International Trade Law \\
\hline USAF & - United States Air Force \\
\hline VIRTEC & - Organização Virtual de Tecnologia \\
\hline VISHOF & - Virtual Shop Floor \\
\hline
\end{tabular}




\section{RESUMO}

OLIVEIRA, T. A. M. (2000). Proposta de uma infra-estrutura jurídica para Organizações e Empresas Virtuais. São Carlos, 2000. 10X p. Dissertação (Mestrado) - Escola de Engenharia de São Carlos, Universidade de São Paulo.

Organizações Virtuais constituem uma modalidade de cooperação entre empresas com contornos inovadores, especialmente no que diz respeito aos seus processos de configuração, dissolução e reconfiguração. Estes acontecem repetidamente em um período relativamente curto de tempo, com uma certa variabilidade de parceiros tirados de um grupo previamente articulado pela tecnologia de informação, com vistas a oportunidades únicas de negócios. Não existem modelos legais pré-concebidos que comportem isoladamente esse propósito de negócio único e que sejam simultaneamente ágeis para se adaptar a novas oportunidades sem maiores custos. A experiência internacional tem demonstrado que a utilização isolada dos mecanismos tradicionais não suporta a complexidade das relações que se estabelecem entre os parceiros, que culmina com o surgimento daquilo que passou a denominar-se Empresa Virtual. Nesse sentido são anlisados os atributos mais imortantes a serem preservados nesse tipo de cooperação bem como as inúmeras possibilidades e barreiras encontradas na legislação, a fim de identificar o mecanismo mais adequado dentro da permissividade legal e adaptá-lo às novas exigências.

Palavras-chave: parceria; empresa virtual; infra-estrutura jurídica; contrato. 


\section{ABSTRACT}

OLIVEIRA, T. A. M. (2000). Proposal of a legal infrastruture for Virtual Organizations and Enterprises. São Carlos, 2000. 10X p. Dissertação (Mestrado) - Escola de Engenharia de São Carlos, Universidade de São Paulo.

Virtual Organizations constitute a new model of cooperation between companies with innovator profile, especially in its configuration processes, dissolution and reconfiguration. These occurrences happen frequently in a short period of time, with some changes in partners that are removed from one group arranged before by information technology, seeking for unique business opportunities. There are no pre-concept legal model that isolated support this unique business propose and be fast enough to adapt itself to new opportunities without increasing costs. International experience has shown that isolated use of traditional mechanisms do not support the complex relation established among partners, that culminate with the arising of which is called Virtual Enterprise. By this way, the most important features to be preserved in these kind of cooperation are analyzed, as well as its uncountable possibilities and barriers found in law, to identify the most adequate legal mechanism and adapt it to new exigencies.

Keywords: partnership; virtual enterprise; legal infrastructure; contract 


\section{Introdução}

\subsection{Localização do trabalho}

A globalização da economia, aqui considerada em seu aspecto concorrencial, vem impondo às empresas de todos os tamanhos uma adequação estrutural que permita atender mercados cada vez mais voláteis, exigentes e pulverizados. A redução do ciclo de vida dos produtos exige maior flexibilidade das empresas, com estruturas mais enxutas não apenas para suportar períodos de retração da demanda, mas para encetar oportunidades únicas de negócios, espalhadas pelo mercado global. Por razões diferentes, empresas de grande e pequeno porte são levadas à cooperar com fornecedores, clientes e concorrentes. "Empresas de grande porte procuram reduzir sua estrutura fixa e em substituição ampliar suas parcerias; empresas de pequeno porte unem-se para complementar seus recursos e suprir suas deficiências" (CAMARINHA-MATOS E AFSARMANESH, 1999) .

A cooperação entre empresas embora não constitua novidade, vem se adaptando também aos novos desafios da concorrência dinâmica. Atualmente, um termo encontrado com destaque na literatura para a cooperação é o de redes de empresas. Uma forma recente de rede de empresas ou cooperação é a Empresa Virtual, descrita inicialmente por Davidow, adequada principalmente ao atendimento de oportunidades específicas, mudanças no ambiente de negócio ou então à realização de uma missão. 
Dentre as várias formas de cooperação praticadas pelas empresas atualmente, merecerão atenção especial neste trabalho as organizações e empresas virtuais, tendo em conta as principais caracteristicas que as definem, tais como oportunismo, excelência, tecnologia, ausência de fronteiras e confiança. Desse conjunto de atributos, que em verdade constituem objetivos da cooperação, emerge algo inédito no campo das ciências jurídicas, e que sequer foi objeto de regulamentação legal até a presente data em solo brasileiro.

Com efeito, os primeiros e principais exemplos dessa modalidade de cooperação têem sede na Europa e Estados Unidos, que se notabilizam por possuirem sistemas jurídicos acentuadamente diferentes ou, quando não, por ostentarem maior maturidade social, apta a suportar os processos de formação de dissolução de Empresas Virtuais, que dependem de estabilidade e confiabilidade dos parceiros para seu êxito.

A diferença básica das Empresas Virtuais para outros modelos de cooperação é a frequência e a intensidade da cooperação, ou seja, a configuração, dissolução e reconfiguração acontecem repetidamente em um período relativamente curto de tempo, com uma certa variabilidade de parceiros tirados de um grupo de empreendedores e empreendimentos previamente articulado. 
É certo, por outro lado, que em determinadas situações cada configuração estará muito próxima de modelos jurídicos preexistentes, justamente pela utilização de mecanismos organizacionais que não são necessariamente novos, tais como joint venture contratual, joint venture corporativa, licenciamento de marcas e patentes, terceirização, acordo cooperativo etc. Entretanto, as exigências do dinamismo se contrapõem tanto à inflexibilidade, quanto à limitação desses modelos. A experiência internacional tem demonstrado que a utilização isolada desses mecanismos tradicionais não suporta a complexidade das relações que se estabelecem entre os parceiros, que culmina com o surgimento daquilo que passou a denominar-se Empresa Virtual. Com efeito essas relações são tão sui generis que "o observador externo vê uma estrutura quase sem contornos, com linhas de divisão constantemente mutáveis entre as empresas, fornecedores e clientes" (GOLDMAN et al., 1995).

Ao contrário das Joint Ventures, tenta-se evitar nas EV formas legais de relacionamento, baseando-se fortemente na confiança. Desta forma, permite-se uma rápida configuração e melhor adequação a oportunidades únicas de negócio. Por outro lado, cria-se um risco de conflitos posteriores à cooperação, principalmente na propriedade intelectual das soluções desenvolvidas.

É possível constatar esse anacronismo a partir da leitura dos principais elementos que compõem a definição para EV dada por BYRNE(1993): "EV é uma rede temporária de empresas independentes - fornecedores e clientes, até mesmo rivais - interligadas por tecnologia de informação, para compartilhar habilidades, custos e permitir o acesso comum aos mercados dos mesmos. Não possui escritório central nem organograma, hierarquia ou integração vertical. Na mais pura forma do conceito, cada empresa que se liga com outras para criar uma EV, será requisitada por sua essência. Ou seja, contribuirão apenas aquelas que se ocuparem com suas competências essenciais" 
O Direito Positivo, que consiste no conjunto de regras editadas pelo Estado, está em constante transformação, procurando interpretar e disciplinar situações novas criadas pela sociedade subjacente. No âmbito dos empreendimentos comerciais privados, especialmente no setor financeiro e de alta tecnologia, a defasagem entre o fato e sua posterior regulamentação é ainda mais acentuada, tendo em vista a velocidade das mudanças e a criatividade dos empreendedores.

Entretanto, a experiência vivida pelas Empresas Virtuais está a demonstrar que quanto mais aperfeiçoada a democracia e melhor representada nos governos a intelectualidade, menor o tempo de set up do sistema legal, na busca da regulamentação .Observe-se ainda que o sentido dessa regulamentação não é o de embotar as iniciativas dos particulares, criando-lhes obstáculos de natureza tributária, criminal, cartorária etc. Ao contrário, o objetivo é apoiar a iniciativa, reconhecendo a existência de uma alternativa boa ao incremento dos negócios.

No caso do presente trabalho, o que se pretende demonstrar é que as Organizações e Empresas Virtuais, em vista de seu surgimento e desenvolvimento recente estão à mercê de um vazio regulamentar e, quando muito, nos pontos isolados que tangenciam a legislação vigente, poderão defrontar-se com exigências contrárias à própria qualidade de ser virtual. Esta é a principal justificativa para o desenvolvimento do presente trabalho.

\subsection{Objetivo}

O que se pretende fazer é propor mecanismos jurídicos que suportem todo o processo organizacional de empresas virtuais, e que em conjunto constituam uma infra-estrutura jurídica. Com efeito, a idéia de infra-estrutura legal é muitas vezes invocada como sugestão de trabalhos e pesquisas, muito mais do que algo já concebido, confirmando o crescimento dessa modalidade de cooperação, seus contornos inovadores e a carência de regras e estudos nessa área. 
A partir dos conceitos de Organização Virtual e Empresa Virtual, da observação de experiências internacionais, de uma visão geral do nosso sistema jurídico e da aplicação prática a um caso concreto, pretende-se chegar a uma ou mais soluções ideais que dêem respostas às exigências integrantes da definição daqueles conceitos e que permitam superar as barreiras já identificadas na doutrina e aquelas que forem acrescidas ao longo da argumentação.

Segundo CAMARINHA-MATOS (1999) os contratos são o principal veículo que regula a execução geral dos processos de negócios entre empresas, partindo desse pressuposto, o presente trabalho terá num modelo contratual seu eixo de desenvolvimento. Este modelo contratual deverá levar em consideração as peculiaridades do direito brasileiro, sua origem histórica, e na aplicação pratica do caso e as expectativas dos empresários diretamente envolvidos.

Para atingir o objetivo central proposto, qual seja definir mecanismos juridicamente válidos que denominamos infra-estrutura jurídica que viabilizem o surgimento e a operação de empresas virtuais, foram definidos objetivos intermediários, descritos a seguir:

- $\quad$ Estudar os processos de organizações virtuais e empresas virtuais, identificando as necessidades jurídicas pertinentes a todo o processo, desde sua formação até sua dissolução;

- $\quad$ Sistematizar essas necessidades segundo um padrão adequado às normas e aos costumes brasileiros;

- Comparar os mecanismos jurídicos tradicionais existentes com os mecanismos exigidos pelas Empresas e Organizações Virtuais.

- Aplicar tal conjunto proposto a uma organização virtual existente, ligada ao Núcleo de Manufatura Avançada (NUMA), atualmente em funcionamento, sob o nome de Oganização Virtual de Tecnologia (VIRTEC). 


\subsection{Metodologia}

Tendo em vista a localização do tema proposto, qual seja uma interface entre engenharia ou administração e direito, o principal suporte para o desenvolvimento do trabalho será a pesquisa bibliográfica descritivo-analítica, com pouco apoio em experimentação ou pesquisa de campo, justamente pela ausência de observação e descrição detalhada de casos concretos na literatura.

Levar-se-á em conta e naquilo que for pertinente, a indução e a dedução, como métodos próprios do Direito. Pelas razões que já foram expostas haverá o prejuízo de um apoio rigoroso e objetivo de uma documentação empírica, e talvez bibliográfica no que respeita ao Direito. Nesse campo de conhecimento, serão aproveitados os conceitos e definições mais correntes e o texto das leis em vigor, como premissas verdadeiras, a partir das quais o método dedutivo terá sua aplicação. De outra parte, no que concerne à observação do fenômeno do ponto de vista da administração, haverá um encontro com o direito por indução, ou seja, da análise dos casos particularmente relatados ou teoricamente considerados, serão tirados elementos caracterizadores e generalizáveis.

A falta de apoio, entretanto, em aparatos empíricos, que são escassos, terá como conseqüência uma certa aproximação do trabalho a uma metodologia de ensaio teórico, justamente pelo tipo de postura que o enfrentamento do tema exige: "um estudo bem desenvolvido, formal, discursivo e concludente, consistindo em exposição lógica e reflexiva e em argumentação rigorosa com alto nível de interpretação e julgamento pessoal" (SEVERINO, 1996). 


\subsection{Estrutura do trabalho}

Além deste capítulo introdutório onde estão delimitados o escopo os objetivos principais e a metodologia, seguem-se o Capítulo 2, destinado à pesquisa bibliográfica, que divide-se em duas partes, cada qual correspondendo a uma das áreas de conhecimento em contato. De um lado a pesquisa é direcionada para a fixação de algumas definições de Organizações Virtuais e Empresas Virtuais, com a identificação de problemas teóricos e sugestões de linhas de pesquisas, de outro, já na área jurídica são pesquisados os temas ligados à tipologia dos sistemas jurídicos, à atividade empresarial, à técnica contratual e temas correlacionados aos atributos das empresas virtuais.

No Capítulo 3, são abordados temas de interesse para a Teoria Geral da Administração relacionados a um visão de sistemas e estrutura a serem considerados na concepção do objeto principal deste trabalho. Neste passo são fixados os contornos de uma OV, descrevendo-se seus principais atributos e definindo-se os processos integrantes do modelo.

A partir do Capítulo 4, com base nos aspectos diferenciadores das EV e OV das demais formas de cooperação industrial, procede-se a uma análise dos aspectos legais almejados, com exclusão de modelos preexistentes que se reputarem inaplicáveis. $\mathrm{Na}$ literatura selecionada, são identificadas regras que garantem a liberdade de criação por parte de indivíduos e empresas nas suas relações particulares. Nesta etapa, são eleitos modelos contratuais e cláusulas, que dentro da licitude e liberdade de criação, são articulados de forma a contemplar as principais exigências das EV e OV.

Ao Capítulo 5 foi reservado o papel de descrever a utilização do um modelo contratual concebido, com algumas adaptações, no sentido de que garantir a sedimentação de um cluster, em torno das empresas que já tinham aderido ao projeto Virtec. Em função da 
natureza da participação de seus membros, forma feitas pequenas adaptações que não significam ruptura com o modelo abstratamente concebido, servindo inclusive para demonstrar a flexibilidade e adaptabilidade do modelo proposto.

Finalmente, no Capítulo 6 são apresentadas as principais conclusões e perspectivas para as $\mathrm{OV}$ e EV, dentro do quadro legal brasileiro atual. 


\section{Revisão Bibliográfica}

\subsection{Organizações e Empresas Virtuais}

\subsubsection{Conceito de Empresa Virtual}

É válido discutir o temo virtualantes de se passar às diversas definições existentes. No sentido organizacional - ou institucional - virtual está ligado ao fato de o objeto 'organização' se apresentar “...quase sem contornos, com linhas de divisão constantemente mutáveis entre as empresas, fornecedores e clientes“ (DAVIDOW \& MALONE, 1993). Outros autores colocam o termo relacionando-o a recursos computacionais (conforme descrito acima), o que de uma maneira geral significa que todos os atributos de um objeto estão presentes, exceto o objeto em si. Numa abordagem comum, o objeto resultante passa a ter os atributos de uma empresa tradicional, sem legalmente (juridicamente) sê-la.

BYRNE (1993) contribuiu com uma definição para EV que se tornou bastante difundida: "EV é uma rede temporária de empresas independentes - fornecedores e clientes, até mesmo rivais - interligadas por tecnologia de informação, para compartilhar habilidades, custos e permitir o acesso comum aos mercados dos mesmos. Não possui escritório central nem organograma, hierarquia ou integração vertical. Na mais pura forma do conceito, cada empresa que se liga com outras para criar uma EV, será requisitada por sua essência. Ou seja, contribuirão apenas aquelas que se ocuparem com suas competências essenciais “ (BYRNE, 1993).

MERTENS (1994) define EV como “cooperação entre empresas para a realização de missões, nas quais desiste-se da formação de novas instalações ou da formalização contratual 
através de Joint Ventures ou Consórcios, ou mesmo da compra de novas filiais" (MERTENS, 1994). Ainda segundo MERTENS (1994), a EV determina o extremo domínio da estrutura operacional sobre a estrutura organizacional. Conseqüentemente, é vista como um progresso não somente de organizações orientadas por processos, mas também da integração do processamento de informações entre empresas.

A definição de EV apresentada por ZIMMERMANN (1997) é “...EV é uma combinação das melhores competências essenciais por classe de empresas, sendo tais empresas cooperativas e legalmente independentes. A junção se dá pelo uso de Tecnologia da Informação por um período de tempo, até que se atinja uma certa meta numa oportunidade de negócio, sem se considerar empresa ou fronteiras geográficas. Isto é atingido sem quaisquer planejamento rígido ou mecanismos de controle" (ZIMMERMANN, 1997).

Empresas Virtuais podem ser definidas como um meio de se organizar atividades de negócios, onde diferentes e independentes parceiros exploram uma oportunidade de negócio específica através da implantação de cooperação de empresas (DAVIDOW \& MALONE (1993)). A virtualidade passa então a ser a habilidade de oferecer aos clientes produtos ou serviços completos, onde a empresa em si reúne apenas algumas das competências necessárias (SIEBER (1997)). Outras competências que se tornem requisitadas poderão ser atingidas pela cooperação.

OKSANA \& HÄRTLING (1995) colocam de forma sintética as diversas definições de EV que podem ser encontradas, envolvendo os diferentes aspectos envolvidos, como uso de Tecnologia da Informação (TI), distribuição de responsabilidades e foco em Competências Essenciais (CEs). Na sua percepção, uma EV é uma forma legal de cooperação entre 
empresas, pessoas e/ou instituições independentes, as quais formam uma capacidade comum de entendimento sobre um negócio. As unidades cooperadoras dividem o trabalho de acordo com suas competências essenciais e atuam na geração de ofertas sobre terceiros como unidade básica. A institucionalização de órgãos centrais para o desenvolvimento, realização e gerenciamento de Empresas Virtuais não é necessária

Segundo GOLDMAN et al. (1995), Empresas Virtuais são uma ferramenta organizacional para empresas dinâmicas, que buscam assim serem mais ágeis que seu concorrentes. Ainda segundo GOLDMAN et al. (1995), entre as razões estratégicas para adoção do modelo de EV destacam-se:

- O compartilhamento de recursos, instalações e eventualmente competências, a fim de ampliar o alcance geográfico ou tamanho aparente que um concorrente pode oferecer a um cliente e

- a divisão dos riscos e custos de infra-estrutura para candidatar-se à concorrência.

As EVs são fortemente baseadas na confiança mútua entre os parceiros. Ao contrário das Joint Ventures, tenta-se evitar nas EV formas legais de relacionamento. Por um lado, torna-se possível uma rápida configuração e melhor adequação a oportunidades únicas de negócio. Porém, cria-se um risco de conflitos posteriores à cooperação, principalmente na propriedade intelectual das soluções desenvolvidas.

Segundo GORANSON (1995), existem quatro tipos de empresas virtuais:

- direcionada a oportunidade, onde uma empresa ou instituição identifica uma oportunidade ou mudança e geralmente atua como organizador de uma EV para satisfazer uma oportunidade;

- direcionada a capabilidade, considerada uma agregação de competências já existentes, buscando então uma oportunidade, 
- cadeia de fornecedores, caracterizada como uma forma relativamente convencional de cooperação, que apresenta porém aspectos que lhe permitem responder rapidamente a oportunidades

- consórcio, semelhante ao exemplo anterior, mas diferencia-se na relação entre os parceiros, que atuam em conjunto frente a oportunidade.

\section{Características de Empresas Virtuais}

Empresas virtuais podem ser descritas por cinco características básicas segundo BREMER et al. (1999):

- especialização nas competências essenciais (core competences). Segundo HAMEL \& PRAHALAD (1995), as empresas tendem cada vez mais a desenvolverem suas competências, tornando-se especializadas em determinado conhecimento. A partir deste conhecimento, isoladamente ou em cooperações, desenvolvem então novos negócios ou produtos;

- cooperação pró-ativa, que significa uma empresa participar de uma cooperação tomando decisões com base nas suas prioridades, mas levando em consideração os demais parceiros. Desta forma, uma empresa cria uma cultura propícia para cooperações baseadas na confiança;

- negócios baseados em oportunidades, que é a estratégia principal de negócios de Empresas Virtuais. Clientes que buscam soluções individualizadas, ainda mais se pressionados pelo tempo, estão geralmente dipostos a atribuir um valor maior ao produto ou serviço. "Tais mercados não são atendidos por empresas baseadas na produção em massa, e apenas parcialmente pelas empresas baseadas na produção enxuta" (KHURANA , 1996); 
- organização virtual, ou seja, adotar como estratégia o uso constante de recursos externos à empresa. Dentro desta estratégia estão a criação de escritórios virtuais, o emprego de tele-trabalhadores, a ampla utilização de ferrramentas de telecooperação, entre outros. Por detrás desta estratégia encontra-se a forte utilização das novas tecnologias de informação,e finalmente

- capacidade de integração, ou seja, a capacidade de se unir rapidamente a redes de empresas. Esta capacidade vai desde a existência de recursos para a troca de informações, até e principalmente na capacidade da organização (pessoas de todos os níveis da hierarquia) se integrarem com outras organizações. Este ponto releva a importância do caráter cultural e comportamental nas EV.

Na verdade, a idéia de Empresas Virtuais não é nada nova e tem sido usada em alguns setores de negócios por vários anos, segundo GROOS (1997). “As mudanças na sociedade como um todo, assim como as novas tecnologias de comunicação e informação, têm tornado as Empresas Virtuais viáveis para um maior leque de empresas, tanto econômica quanto estrategicamente" (EVERSHEIM, 1997).

ZIMMERMANN (1997) ressalta que Empresas Virtuais são conseqüência do desenvolvimento da Tecnologia de Informação, induzido pelas reconfigurações nos negócios por abordagens como reengenharia, orientação a processos de negócios ou TQM. Estas outras abordagens suportaram a evolução de novas formas organizacionais (Figura 1) que culminassem no conceito de Empresas Virtuais. 


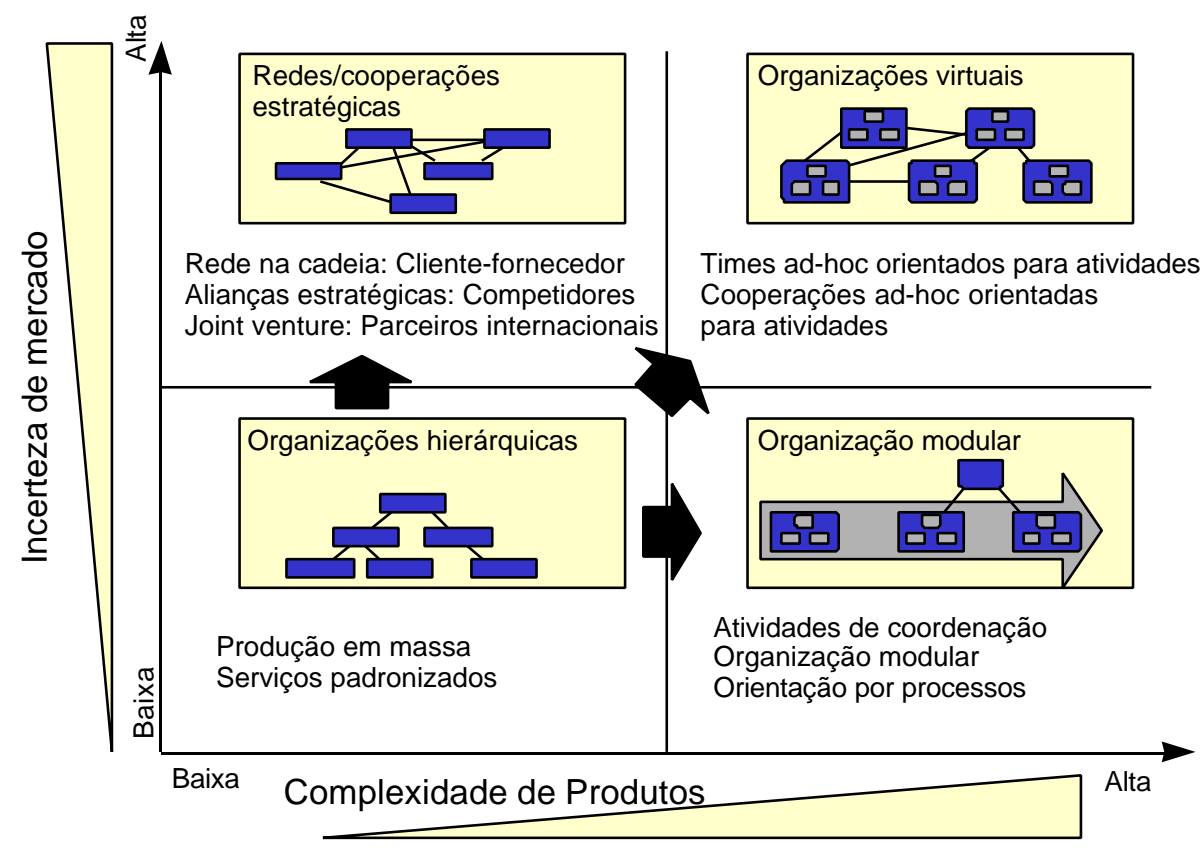

Figura 1 - Perspectivas do Desenvolvimento Organizacional

Adaptado de PRIBILLA et al. (1996).

Segundo BYRNE(1993), os atributos-chave a serem atendidos pelas OV e EV são:

Excelência: cada parceiro contribui com sua "competência essencial" ao esforço total. Cada função e processo deve ser de classe mundial, o que às vezes não é possível de ser alcançado por uma companhia sozinha.

Tecnologia: redes de informação ajudarão companhias e empreendedores a se juntarem e trabalhar em equipe do início ao fim.

Oportunismo: parcerias serão menos permanentes e mais oportunistas. As companhias trabalharão juntas de modo a satisfazer uma oportunidade de negócio específica, separando-se em seguida. 
Confiança: o sucesso da Corporação Virtual depende do grau de confiança e cooperação entre seus membros.

Ausência de Fronteiras: A tecnologia e a globalização do negócio mundial permite aos membros da corporação estarem geograficamente distribuídos.

\subsubsection{Infra-estruturas exigidas segundo alguns modelos de Empresas Virtuais}

A seguir serão colocados dois modelos propostos para a formação de Empresas Virtuais. Ambas as abordagens pressupõe que as EVs surgem unicamente de oportunidade de negócios, não sendo necessário antes existir uma base comum de cooperação que sirva de plataforma para a formação de Empresas Virtuais. Este tipo de plataforma será discutido posteriormente e é também conhecida por Organização Virtual.

\section{O Modelo AVE (Agile Virtual Enterprise)}

Uma entidade da indústria de manufatura norte americana - "Agile Manufacturing Enterprise Forum"(AMEF) - propôs um modelo para a exploração de negócios por meio de Empresas Virtuais. Neste modelo é mostrado um ciclo de vida de Empresas Virtuais, cujo nome é Empresas Virtuais Dinâmicas, segundo GORANSON (1995). Este modelo representa uma EV através de um estrutura que descreve os processos de uma AVE desde sua criação até dissolução (Figura 2). Cada processo envolve decisões as quais usam ferramentas e métodos cuja eficácia deve ser informada por métricas. Além dos processos o modelo também define quatro infra-estruturas.

Tais infra-estruturas suportam todo o ciclo de vida de uma AVE, e não somente uma simples composição ou reunião dos parceiros. Além disto, as métricas são implantadas nas infra-estruturas para medir o desempenho dos processos. 


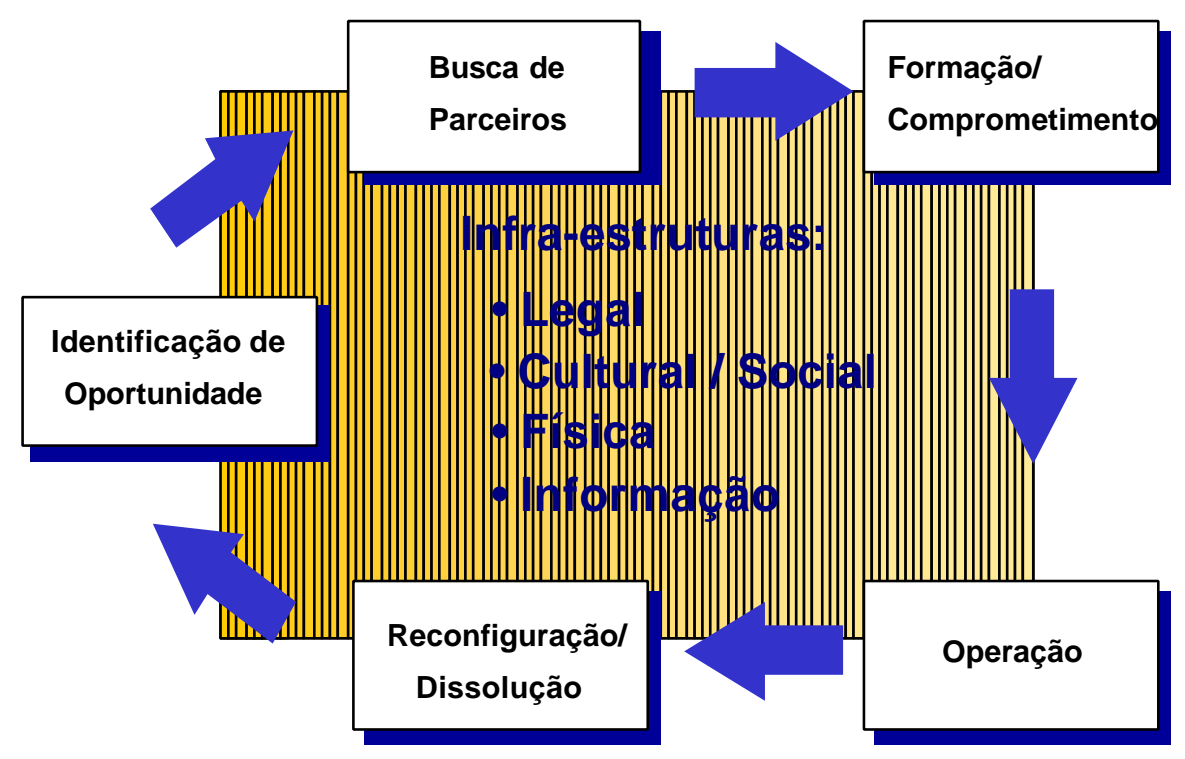

Figura 2- Modelo AVE (Agile Virtual Enterprise)

\section{Adaptado de GORANSON (1995)}

As infra-estruturas, brevemente descritas tratam de:

- Legal: define a forma de como o negócio será dirigido, a cadeia das responsabilidades gerenciais. Adicionalmente, inclui as regras que definem a divisão de trabalho, forma de relacionamento entre parceiros e regras, códigos e regulamentações da Empresa Virtual;

- Cultural/Social: a partir de padrões de comportamento humano, define regras de comportamento dentro da cooperação, modos de interação pessoal e em grupo, próatividade, capacidade em interagir e problemas afins;

- Física: lida com questões relativas à movimentação, uso e armazenamento compartilhado de bens, equipamentos e pessoal; 
- Informação: lida com a natureza da comunicação feita na EV, a partir de meios básicos de comunicação e coordenação, como notações verbais, escritas, gráficas e suas abstrações lógicas.

Vale a pena destacar que a proposta da AVE surgiu do esforço da indústria militar norte-americana em definir e implementar o que se chama de manufatura ágil, num programa financiado pelo DARPA (Defense Advanced Research Projects Agency) e pela USAF (United States Air Force). O fato é que a indústria militar gera considerável parte dos postos de trabalho na indústria norte-americana, e, frente à nova ordem econômica e política global, tornou-se necessário uma reestruturação do setor, não apenas em busca de eficiência, mas de competitividade, já que perderam a importância estratégica e o status confortável que detinham.

\section{O Modelo AAMRC (Agile Aerospace Manufacturing Research Center)}

Segundo REID et al. (1996), o modelo proposto pela AAMRC assume que uma Empresa Virtual se coloca num ciclo, composto por seis elementos (Figura 3). Este processo de seis etapas pode ser entendido como sendo o ciclo de vida de uma Empresa Virtual. A seguir, serão brevemente descritos:

- Concepção: uma Empresa Virtual surge ao ser detectada uma necessidade de mercado e ao se estabelecer um objetivo. Nesta etapa, é necessário conhecer as expectativas/necessidades do cliente e o que irá satisfazê-lo. Articula-se a estratégia e o desenho conceitual da nova EV;

- Criação: com o estabelecimento de relações entre os parceiros, a EV é criada. Nesta fase, os parceiros irão desenvolver e implementar novos processos e sistemas que suportarão as demais etapas do ciclo. A EV é desenhada detalhadamente e é feita uma preparação completa para sua implementação; 
- Competição: a EV passa a competir quando é feita a divulgação do produto no mercado. Esta etapa pode ser realizada de diferentes formas. A EV pode oferecer novas soluções alternativas para necessidades imprevistas, cativando novos clientes;

- Configuração: a EV é configurada como um conjunto de ativos, as competências necessárias são adquiridas e são empregadas as infra-estruturas necessárias para se rodar a EV. Os ativos, processos e procedimentos são então desenvolvidos ou adquiridos e integrados da forma especificada, a fim de a EV produzir e entregar o produto requerido. Estas atividades encerram a implementação da nova EV;

- Condução (Operação): a EV simplesmente começa a produzir e entregar seu produto, buscando valorizar ao máximo a contribuição de seus parceiros;

- Conclusão (Dissolução ou Reconfiguração): uma satisfeita a oportunidade de negócio da EV, ocorre a dispersão ou reaproveitamento dos ativos envolvidos.



Figura 3- Ciclo de vida para Empresas Virtuais

Adaptado de REID et al. (1996). 
As atividades deste modelo são desempenhadas sempre por processos detidos e operados pelos membros da Empresa Virtual, ou, por processos compartilhados entre empresas numa entidade corporativa. O fato de os processos serem desempenhados de forma individual ou compartilhada depende muito de quais são os objetivos e de como se deseja alcançá-los.

\section{Modelos de Empresas Virtuais com Broker (Agenciador)}

Foi proposto por MERTENS (1994), um modelo que evidencia a importância de um Broker (Agenciador) na formação de Empresas Virtuais (Figura 4).

Neste modelo, num estágio zero, parte-se de duas empresas situadas em regiões distintas, sendo cada uma caracterizada por uma cadeia de competências (A1, B1, .., E1). Durante a evolução da cooperação até o nível de Empresa Virtual - representada pelo estágio 4 - as empresas fazem o intercâmbio de suas competências, de forma bilateral. Desta forma, não contradizem o conceito de concentração em competências essenciais (estágio 1). Numa fase seguinte, a empresa A passa a buscar competências externamente à cooperação com a Empresa B, criando um maior número de parceiros. Consequentemente, a empresa A adotou as competências $\mathrm{C} 1$ e D1 como sendo essenciais. 




Figura 4- A caracterização do Broker na formação de Empresas Virtuais

Adaptado de MERTENS (1994).

No estágio 3, os clientes e fornecedores são inseridos na cadeia de competências. A visão proposta por MERTENS (1994), a comunicação e a coordenação da rede é feita por entidades de negócios independentes, os agenciadores ou Brokers (estágio 4). A seguir, será apresentada uma definição desta funcionalidade.

A funcionalidade e organização deste agenciador tem sido tema de diferentes pesquisas na atualidadei. Uma definição de funcionalidade do Broker é apresentada em seguida.

\section{A Entidade de Negócios Broker (Agenciador)}

Assim como definido na seção anterior, o Broker é uma entidade responsável pela procura de oportunidades de mercado e pelo suporte à formação de Empresas Virtuais. Desta forma, tem como responsabilidades os processos de busca e seleção de parceiros e a 
configuração das infra-estruturas necessárias - analogamente ao definido por GORANSON (1995) e REID et al. (1996) - para a formação e o comprometimento com a EV.

Adicionalmente, o Broker deve ser o coordenador de desenvolvimento e implementação das soluções técnicas a nível de aplicativos, assim como o consultor para a adoção de medidas organizacionais da EV.

Logo, um Broker agiria como um canal entre redes de cooperação e a formação de Empresas Virtuais. Tais redes de cooperação podem seguir o conceito de Organizações Virtuais (OVs)ou o conceito de Grupos Virtuais de Indústria (GVIs), conforme proposto por BREMER et al. (1999). Os conceitos de OV e GVI serão oportunamente apresentados nas seções seguintes.

\subsubsection{Organizações Virtuais}

Antes de definir uma Organização Virtual é necessário compreender o sentido da expressão rede: uma rede pode ser um tipo de organização que se origina como um projeto básico para a construção de um grupo social. No contexto de empresas, redes significam cooperações estáveis ou dinâmicas com a finalidade de explorar oportunidades de mercado.

Sendo assim, uma Organização Virtual pode ser definida como "uma rede estável de empresas, destinada a formação de Empresas Virtuais, interligadas de acordo com suas competências essenciais e estratégias de mercado e suportada pela utilização da tecnologia de informação. No entanto a utilização da tecnologia da informação não consiste em uma condição essencial, mas sim viabilizadora para o aumento da performance de uma cooperação"(KOCIAN \& SCHEER, 1996). 
Uma Organização Virtual - OV - pode então ser vista como uma plataforma estável, onde empresas trocam informações a respeito de oportunidades de mercado. Consequentemente, utilizam-se dessa cooperação para a formação rápida de uma Empresa Virtual, uma vez que uma estrutura organizacional já está presente (Figura 5).

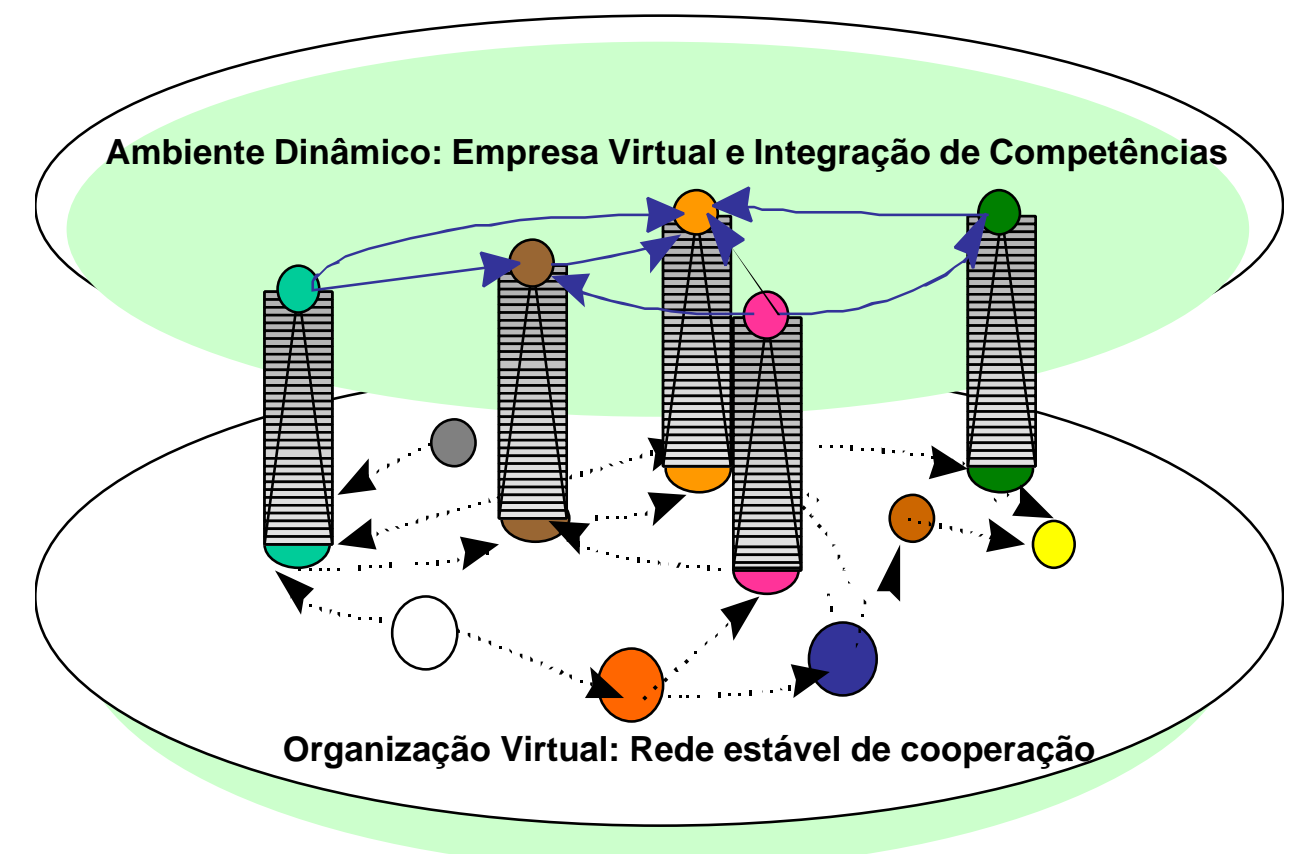

Figura 5- Plataforma de uma Organização Virtual

Adaptado de SCHUH et al. (1997).

De acordo com a Figura 5, podem ser observados três aspectos importantes na formação de Organizações Virtuais. Estes aspectos são a cultura da confiança, a cultura da competência e a cultura da tecnologia da informação.

Ao serem tratadas questões relativas aos interesses corporativos e pessoais dentro da Organização Virtual, a ética a ser implementada e cultivada passa a ser fundamental. Assim sendo, torna-se importante ser aberto e acessível o conhecimento sobre as pessoas e empresas interessadas em fazer parte da Organização Virtual. Muito importante, e talvez 
imprescindível, é o contato pessoal no desenvolvimento desta cultura. A partir do conhecimento mútuo, é possível estabelecer um senso de interesses comuns. Medidas que podem auxiliar na formação da cultura de confiança são:

- desenvolvimento de regras do jogo para a participação na Organização Virtual (código de ética);

- desenvolvimento de políticas de admissão, qualificação e exclusão de membros;

- identificação e exposição de competências essenciais dos membros e

- identificação de mercados potenciais e melhoria de visibilidade de mercado para os membros.

A abordagem de questões não relacionadas aos ativos físicos da Organização Virtual, suas Competências Essenciais, como tecnologias, know-how, processos de negócios e daquelas relacionadas aos ativos fixos - como máquinas, instalações, etc. - é feita pela cultura da competência. Vale ressaltar que, dentre os diversos tipos de recursos envolvidos numa competência essencial (CE), o conhecimento é tido como o mais importante.

A cultura da tecnologia da informação é baseada nos recursos computacionais para o processamento de dados, o que é de vital importância para os processos de comunicação entre os parceiros de uma Organização Virtual, pois a forma eletrônica destes processos contribuem para a redução dos custos de transação. 


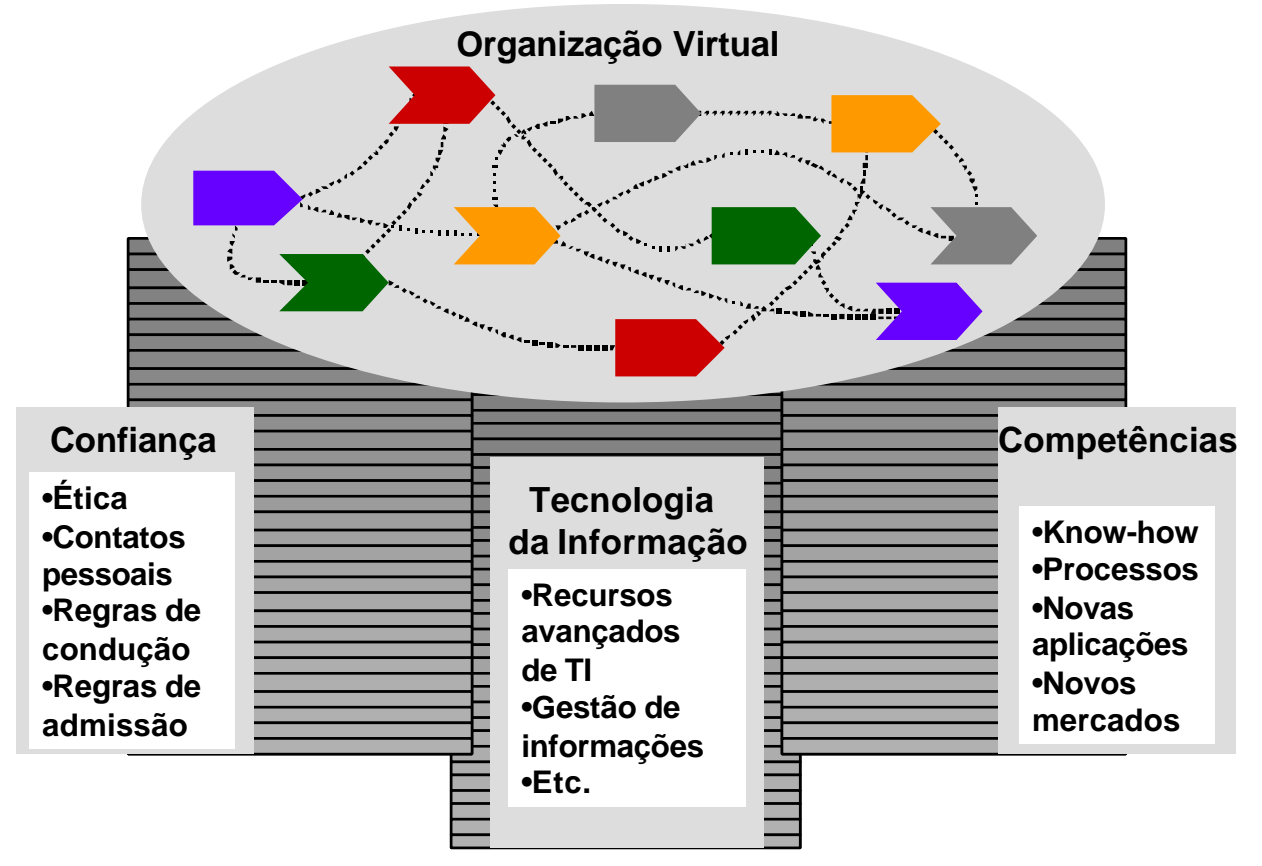

Figura 6- Culturas fundamentais em Organizações Virtuais

Um modelo para se implementar uma Organização Virtual é descrita por SCHUH et al. (1997). Este modelo pode ser observado no projeto Virtuelle Fabrik da Universidade de St. Gallen - Suíça. É composto por quatro fases principais (SCHUH et al., 1997):

1. Esclarecimento: corresponde a interligação de um time básico (o técnico da rede mais cerca de 10 empresas) e a definição dos limites da área de atuação;

2. Planejamento: refere-se ao planejamento de projetos e financiamento;

3. Construção: fundação da rede como uma organização juntamente com a definição de papéis e regras para o processo de coordenação. Nesta fase existe ainda a transferência de know-how para a difusão das competências existentes na rede.

4. Operação: prolongamento da rede através da admissão de novos parceiros e início de aquisição e desenvolvimento de ordens de pedido 
A iniciativa para a formação de uma rede estável pode ter diferentes origens, entre as quais ressalta-se os projetos de pesquisas financiados por instituições governamentais. $\mathrm{Na}$ prática, a formação destas plataformas pode surgir através da expansão da cadeia tradicional de fornecedores à nível regional.

As Organizações Virtuais podem surgir ainda através da exploração de oportunidades em mercado eletrônico ou bolsas de cooperação na Internet. Nesses casos, problemas culturais devido ao não conhecimento profundo dos prováveis parceiros em uma cooperação trazem obstáculos ao sucesso da exploração da oportunidade. Além disso, o acoplamento entre as competências essenciais não é tão forte se comparado àquele em uma rede estável, devido ao menor nível de conhecimento mútuo entre os parceiros.

A estrutura da OV deve ter mecanismos elaborados para suportar o processo de coordenação dos membros, de acordo com as diferentes perspectivas a serem encontradas. A formalização destes mecanismos traz maior transparência na relação entre os parceiros e conseqüentemente atua nos fatores sócio culturais relevantes ao sucesso do empreendimento (KOCIAN (1997)). Consequentemente, uma Organização Virtual pode servir como base para a implementação de mecanismos para a formação e gerência de EVs.

\subsubsection{Dinamismo um novo paradigma}

Segundo GOLDMAN et al. (1995), o mundo da produção em massa estava inteiramente voltado para o fabricante, sem que o cliente individual fizesse parte do processo de decisão a respeito de quais produtos fabricar e de que maneira configurá-los. O fabricante e o cliente eram adversários, e o parâmetro para que houvesse interação era o preço. O fabricante desejava obter mais dinheiro e fornecer menos produto, e o cliente desejava exatamente o contrário. Essa situação provocou um ambiente de rivalidade que se reflete em incontáveis leis e regulamentações. 
No modelo de produção em massa, os recursos de produção definem o produto, que por sua leva a um plano de marketing para se atingir o cliente.

$\mathrm{Na}$ concorrência dinâmica, o cliente trabalha em conjunto com a equipe que obtém recursos através de uma organização virtual, a fim de criar uma solução personalizada.

A concorrência dinâmica e o surgimento das corporações virtuais criam verdadeiros dilemas para o sistema jurídico. Os concorrentes dinâmicos são geralmente parte de uma organização virtual que interage com o cliente de uma forma muito próxima. Uma vez que o cliente é parte do processo que dá origem a um produto ou serviço personalizado, os conceitos tradicionais sobre a relação entre cliente e fornecedor - a independência do cliente em relação ao fornecedor, na verdade, seu rival - estão sofrendo uma mudança gradual.

Há três principais aspectos, segundo GOLDMAN (1995), que caracterizam uma EV :

Uniquidade: uma EV existe para explorar uma única oportunidade de negócio por vez;

$>$ Orientação a Competência: uma EV almeja juntar as melhores competências a fim de preencher a oportunidade, independentemente de sua localização;

Infra-estrutura de Informação Moderna: o uso de tecnologias de informação e comunicação modernas e eficientes (infra-estrutura de informação) permite a formação e gerenciamento de cooperação dinâmica entre parceiros diferentes e também globais.

\subsubsection{Cooperação entre Empresas}

Atualmente, não existe ainda um consenso em como se aplicar corretamente o termo cooperar. Alguns pesquisadores abordam a cooperação como sendo o amplo campo de unidades de negócios que trabalham juntas a fim de alcançar um objetivo comum, por meio da formação de diferentes manifestações de parceria. 
PFOHL (1996) coloca uma cooperação como sendo uma possível manifestação dos vários tipos de relações mantidas por uma empresa e o ambiente no qual ela se insere. O próprio PFOHL (1996) considera que o a cooperação é formada para se alcançar uma meta comum, onde uma característica marcante é a independência legal das empresas envolvidas.

Segundo PICOT et al. (1997), formas de cooperação entre empresas se caracterizam como colaborações contratuais de médio-longo prazo, entre empresas legalmente independentes, voltadas para a conclusão comum de atividades. Apesar de ser possível citar exemplos das vantagens que podem ser obtidas - como redução de risco em novos mercados, economias de escala, aquisição de novas competências - esta definição não explica como ocorre a execução e conclusão das atividades, nem quais são as relações mantidas entre os parceiros.

\subsubsection{Barreiras e Facilitadores na Formação de Cooperação entre Empresas}

Em se tratando de cooperação, não se deve pensar em empresas ou departamentos de empresas trabalhando coonjuntamente, mas em pessoas. Uma cooperação passa então a ser o resultado da combinação de três fatores distintos: o querer cooperar, a liberdade em cooperar e a liberdade em cooperar.

De um lado, fica a necessidade de se abandonar padrões comportamentais antigos, como a busca pela vantagem unilateral, o que pode aumentar o risco de participação de outros parceiros e culminar com uma desconfiança total. 
Conforme HAMEL \& PRAHALAD (1995) colocaram, é necessário não apenas aprender o novo, mas mais importante ainda é esquecer o velho. Isso porque, ao se repensar o modo de agir abre-se a possibilidade de políticas de abertura entre parceiros. Neste modelo, passa-se de um ambiente de guerra de preços baixos para outro de paz de preços alvo comuns (EVERSHEIM et al. (1996a)).

Segundo membros da equipe de TQM do Laboratório de Máquinas Ferramentas da Universidade Técnica de Aachen (Werkzeugmaschinenlabor - Rheinisch-Westfäliche Technische Hochschüle), o sucesso de uma cooperação se baseia tanto em fatores Hard (as habilidades e tecnologias das empresas), como em fatores Soft(a cultura da empresa, seus conhecimentos) (Figura 7).

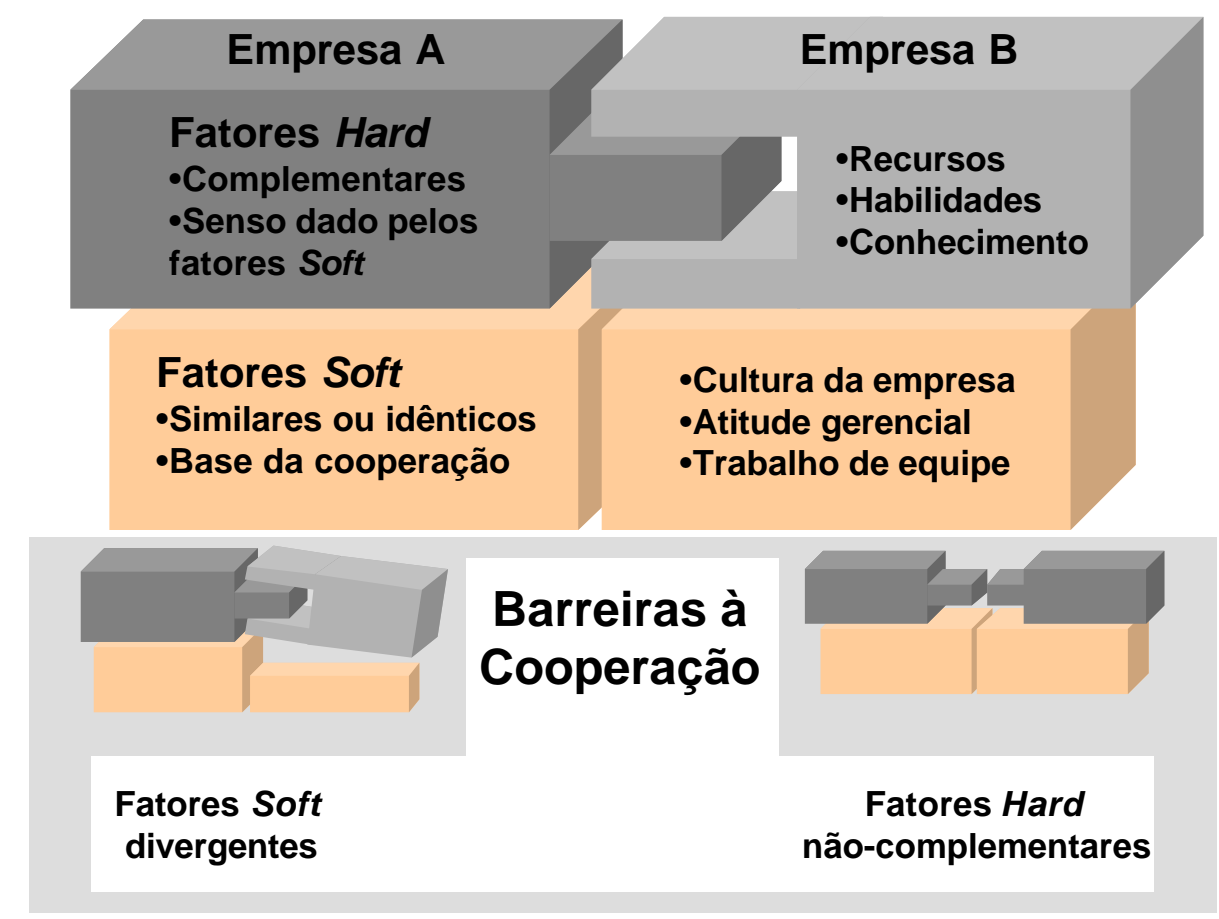

Figura 7 - Barreiras à Cooperação entre Empresas

Adaptado de EVERSHEIM et al. (1996a). 
Os fatores Hard complementares podem ser entendidos como sendo o valor agregado por todos os parceiros da cooperação. Um bom exemplo é a aplicação da metodologia para desenvolvimento de novos produtos de um dos parceiros e dos recursos computacionais de outros. No sentido vertical, um bom exemplo é uma cadeia para produção de carcaças de redutores, onde um dos parceiros faz a fundição, outro a usinagem e um terceiro a montagem.

A prática tem demonstrado que tanto pontos fracos como fortes têm sinergia, o que leva a concluir que uma cooperação demanda a concentração nos pontos fortes das empresas parceiras. Em um ambiente competitivo, a autonomia de uma empresa é sinal de sua força. Então, os parceiros devem manter sua autonomia durante a cooperação, a fim de não se acomodarem, e, acabarem com a prórpia cooperação.

Sozinhos, os fatores Hard não capacitam uma empresa a ser competitiva nem garantem o sucesso de uma cooperação, uma vez que a cooperação exige envolvimento do ser humano, logo do seu comportamento.

Neste ponto, os fatores Soft se colocam como fundamentais para o sucesso da cooperação. É necessário que haja compatibilidade destes fatores, que envolvem cultura corporativa, estilo gerencial, clima de confiança interna, etc. Como são fatores muitas vezes implícitos e não-formalizados, não há como elaborar um checklist das características desejáveis relativas a estes fatores.

Em cooperações internacionais pode haver grande influência dos fatores Soft. De um lado, uma empresa do país A pode ter uma cultura - enraizada nas pessoas - de extrema abertura e coletivismo. Já na parceira do país B, a cultura pode ser de individualismo e ostracismo, o que pode ser um indício de conflitos futuros. 


\section{Formas Organizacionais de Cooperação}

A Joint Venture e o consórcio serão tratados em tópico específico relacionado ao sistema jurídico. Restando a "aliança estratégica" que por não significar um modelo jurídico específico, mas um termo próprio da economia, e que pode representar um gênero dentro do qual se inserem as EVs OVs, convém explicitá-lo.

Alianças são associações para fomentar interesses comuns dos membros de acordos entre empresas. Abrangem uma ampla gama de funções, desde suprimento de componentes, passando por pesquisa e desenvolvimento até a produção e comercialização. Segundo YOSHINO \& RANGAN (1997), três características as definem:

- As duas ou mais empresas que se unem para cumprir um conjunto de metas combinadas, permanecem independentes depois da formação da aliança;

- As empresas parceiras compartilham dos benefícios da aliança e controlam o desempenho das tarefas especificadas, talvez o traço mais distintivo das alianças que dificulta a sua gestão;

- As empresas parceiras contribuem continuamente em uma ou mais áreas estratégicas.

MARCAR (1997) define uma aliança estratégica como um relacionamento de negócios entre empresas, onde compartilham riscos e pontos fortes, ou, integram funções do negócio em prol do benefício comum.

Segundo ELLENRIEDER (1996), "uma aliança estratégica é uma vinculação permanente entre duas empresas, que visa o desenvolvimento sustentável de vantagens competitivas, de diferenciação ou de custo".

Para YOSHINO \& RANGAN (1997), "as alianças têm grande participação neste jogo [da concorrência global]... São críticas para a vitória em termos globais... A maneira menos atraente de tentar vencer em termos globais é pensar que você pode abraçar o mundo sozinho". 
Alianças requerem um elevado nível de comprometimento e uma faixa ampla de integração entre as partes envolvidas. As companhias devem trabalhar extremamente juntas para desenvolver novos produtos, procedimentos para novas instalações e meios de conquistar maior parcela do mercado (LOFTSPRING, 1997a).

\section{Tipos de Alianças Estratégicas}

No intuito de determinar o nível interativo das empresas - que decidem por aliar-se em busca de vantagens competitivas - nos aspectos culturais, tecnológicos e estratégicos, YOSHINO \& RANGAN (1997) propõem uma tipologia de alianças estratégicas (Figura 8):

- Alianças pró- competitivas : relações entre ramos de negócios, em cadeia vertical de valor, bem como entre fabricantes;

- Alianças não- competitivas: são uniões entre ramos de negócios, formadas entre empresas não concorrentes;

- Alianças competitivas: são semelhantes às alianças não- competitivas em termos de atividade conjunta (por isso, também no nível de interação organizacional);

- Alianças pré- competitivas: reúnem tipicamente empresas de ramos de negócios diferentes, geralmente não relacionados, para atuação em atividades bem definidas, como o desenvolvimento de novas tecnologias. 


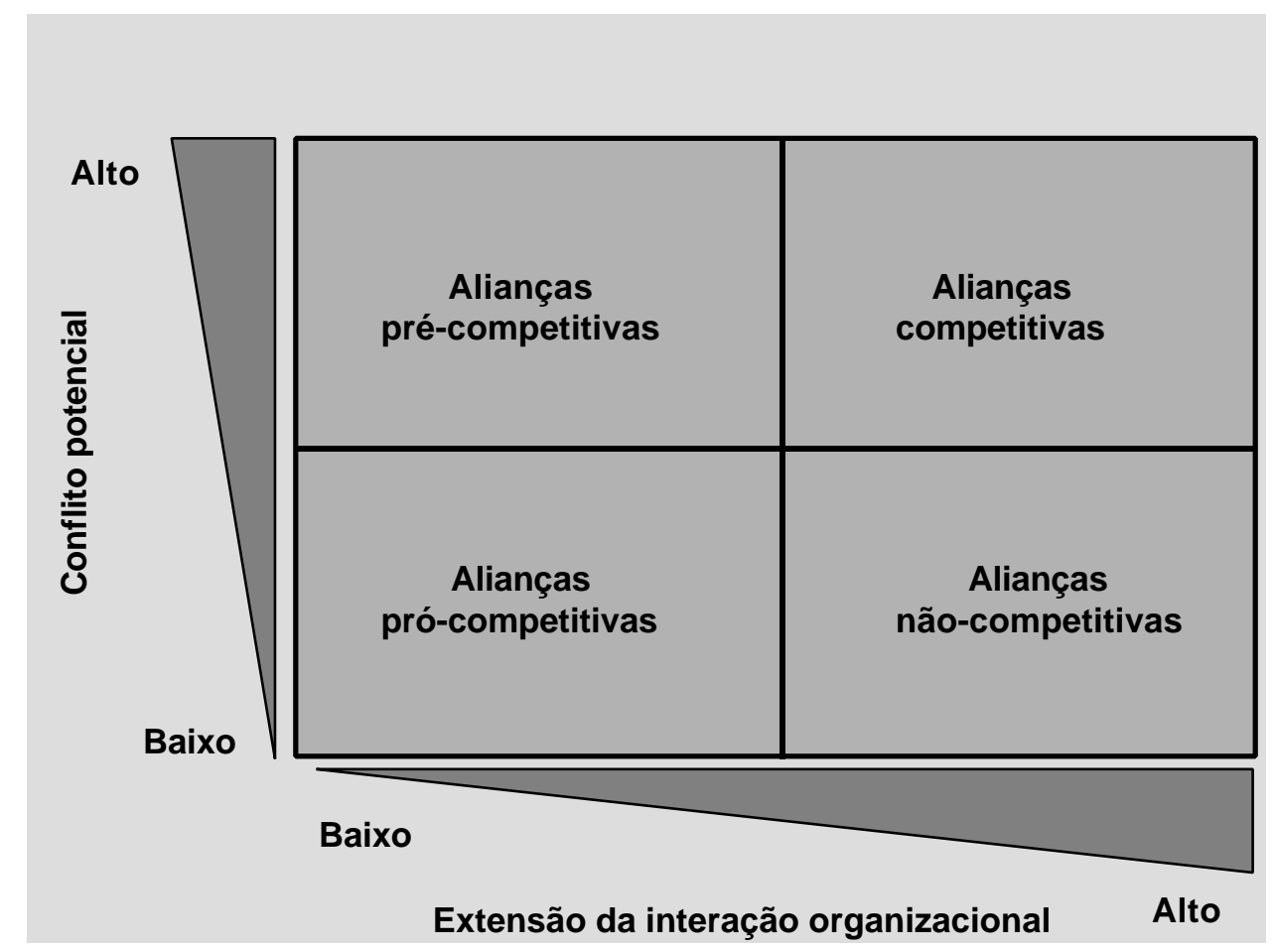

Figura 8- Tipologia de Alianças Estratégicas

Adaptado de YOSHINO \& RANGAN (1997).

Uma outra tipologia, adotada por LOFTSPRING(1997b), classifica as alianças em:

- Cliente- fornecedor: a relação deixa de ser meramente a contratação de um serviço, para ser uma cooperação que visa o aprimoramento ou até o desenvolvimento de um produto. A troca de informações entre clientes e fornecedores durante o processo de desenvolvimento do produto tende a adequálo às necessidades de mercado. Nessa interação, os participantes trabalham como parceiros, analisando e negociando custos, taxa de retorno, valor presente líquido, critérios de medida, incentivos e alocações de riscos. Nesse contexto, a aliança entre clientes e fornecedores torna-se mais estreita;

- Fornecedor- fornecedor: este tipo de relacionamento entre empresas visa a complementaridade de especialidades para suprir possíveis lacunas na cadeia de valores. Com esse tipo de aliança as empresas melhoram as suas capacidades 
competitivas através da divisão de custos e coordenação de habilidades específicaspara atingir um objetivo comum. A divisão de custos ocorre na medida em que são compartilhados desenvolvimentos tecnológicos, otimização de equipamentos e integração de serviços e assistência técnica.

A abordagem sistêmica de custos pressupõe uma Gestão Estratégica de Custos, proposta por GOVINDARAJAN (1995), subdividida em:

- Cadeia de valores: conjunto de atividades que agregam valor desde a fonte de matéria-prima, incluindo fornecedores de componentes e recursos humanos envolvidos, até a entrega ao cliente;

- Posicionamento estratégico: a empresa deve decidir se a diferenciação será em termos de preço ou produto. Além disso, a empresa define o seu nicho de mercado, identifica os concorrentes e estabelece uma estratégia competitiva;

- Direcionados de custos: os direcionadores de custo são identificados por cinco elementos:

- Escala: tamanho do investimento a ser feito em produção, P\&D e Marketing;

口 Escopo: grau de integração vertical;

๑ Complexidade : amplitude da atuação em subsetores ou serviços;

\ Experiência: quantas vezes a empresa fez no passado o que faz atualmente;

- Tecnologia: quais tecnologias de processo são utilizadas em cada fase da cadeia de valor. 


\section{Formação de Alianças Estratégicas}

"O processo de formação é a parte mais importante da constituição de uma aliança estratégica. Especificamente, achamos que um processo de formação bem balanceado e adequadamente executado aumentará a probabilidade de subseqüente sucesso. Achamos que o sucesso não se limita apenas em ir atrás de oportunidades estratégicas conjuntas baseadas na força da aliança para criar valor. Ele depende também de uma base firme da aliança, obtida através de um processo de formação adequado. Mais tarde, pode ser frustrante se as partes perceberem que um negócio de provável sucesso não se materializou em função de um processo de formação inadequado" LORANGE \& ROSS, 1996).

\section{Quando e porque são formadas as alianças estratégicas}

A formação de alianças estratégicas ocorre no momento em que se identifica uma expectativa de expansão de mercado, aquisição de know how tecnológico, oportunidade de negócios e de melhoria da posição competitiva, não viável em outra situação. A aliança provê às empresas constituintes recursos tecnológicos, humanos e financeiros para o atendimento rápido de demanda do mercado.

Segundo MARCAR(1997), a busca de uma aliança para atingir os objetivos de uma organização se dá quando não se opta por pessoal e força gerencial existentes (crescimento interno), não se tem intenção de adquirir uma nova empresa (união e aquisição) e não se acredita que uma unidade ou uma divisão fora da empresa agregará algum valor (spin - off).

Os requisitos essenciais para a formação de alianças estratégicas são: (ELLENRIEDER, 1996)

- Existência de um sistema claro e permanente de planejamento conjunto, para a integração de decisões sobre as operações das duas firmas; 
- A amplitude do acordo deve estar claramente definida no que se refere ao grau de lealdade esperado e às expectativas mútuas a longo prazo;

- A co-participação nos benefícios e custos deve ser contratada;

- Definição do mecanismo de intercâmbio sistemático de informações, referentes às transferências de informações operacionais, oportunas, precisas, concisas e utilizáveis;

- Existência de controles operacionais recíprocos, refletindo a vontade de ambas as partes;

Para o funcionamento desse modelo de parceria, sete fatores críticos devem ser observados, segundo LANGER (1996):

- Desenvolvimento de uma estratégia de parceria;

- Disponibilizando o valor para o parceiro;

- Envolvimento dos fornecedores;

- Conhecimento mútuo;

- Construção de um forte relacionamento de trabalho;

- Evitar dependência.

“ Parceria é a mais importante estratégia de crescimento tecnológico que uma empresa pode ter" (LANGER, 1996).

\section{Acordo para a aliança estratégica}

Um elemento essencial para a formação de uma aliança é a complementaridade natural dos parceiros e a disponibilidade de recursos na aquisição de metas comuns com resultados positivos para todas as partes envolvidas (TRADEWINDS, 1997). 
$\mathrm{Na}$ fase inicial, os parceiros devem ser levados a discutir e deixar claro suas expectativas sobre a aliança. Essa é uma fase crítica onde a disposição dos parceiros de contribuir com recursos (financeiros, de negócio, de engenharia, desenvolvimento) ou a expansão da aliança (disposição de aceitar novos produtos, expandir para novos ramos, entrar em novos mercados) devem ficar muito claras e acertadas para que não venham a comprometer a "saúde" da aliança.

A similaridade de esforços de vários parceiros não é necessariamente um bom indicador de sucesso da aliança. É mais interessante encontrar um parceiro que tenha outras habilidades que possa prover em troca. Isto é fundamental para uma boa colaboração e comunicação com um parceiro e pode ser de natureza técnica, estratégica ou cultural. Além disso, pode ser uma oportunidade excelente para a empresa participar de mercados globalizados.

Um outro ponto crucial no desenvolvimento da aliança é a confiança. Deve-se desenvolver um sentimento de que o participante irá cumprir plenamente com as suas atribuições e essa confiança se desenvolve na medida em os parceiros provam a sua confiabilidade.

Porque a confiança, no seu sentido amplo, se desenvolve com o passar do tempo, nem todas as resistências para a formação da aliança podem ser resolvidas. O risco da formação de alianças só pode ser minimizado se previamente os parceiros são bem escolhidos, as regras e processos são bem definidos e suas expectativas bem claras (PAINTER, 1997).

Sob o aspecto puramente legal uma aliança é como qualquer outra relação comercial baseada em contrato onde são acordados deveres e obrigações. Sob as leis da maioria das jurisdições, uma aliança ou qualquer outro tipo de arranjo de "joint venturing" é tratada por vários propósitos como uma cooperação. (LOFSTRING, 1997c). Um contrato para a formalização de uma aliança deve ser firmado na medida em que não haja perda significativa de sua flexibilidade. 
A filosofia convencional de contrato dita que cada parceiro deve ser responsável pelos prejuízos e danos que ele causa. Isso protege os parceiros não envolvidos no incidente de perdas que estavam além do seu controle, mas também é inevitável que isso leve a um desentendimento e freqüente litígio entre os parceiros afetados. (LOFTSPRING, 1997c)

Ainda segundo LOFTSPRING (1997c), projetos recentes de alianças têm optado por distribuir igualmente as perdas entre os membros da aliança. A lógica por trás dessa estratégia está em eliminar a probabilidade de disputas, motivando os membros a trabalhar em grupo, buscando uma solução comum para os problemas e sobrepujando a atitude de cooperação.

Atenção especial deve ser despendida não para meramente estabelecer objetivos comuns entre os parceiros, mas para alinhar os seus interesses - risco principalmente - para que os membros possam trabalhar eficientemente direcionados para os objetivos da aliança.

\subsubsection{Barreiras jurídicas à assimilação do dinamismo}

GOLDMAN et al. (1995) mencionam um estudo realizado por um grupo de executivos do setor nos Estados Unidos através do Iacocca Institute em 1991 e elenca alguns aspectos que demonstram o inadequação dos aparatos jurídicos frente ao novo paradigma do dinamismo, que mutatis mutandi, também tem o mesmo efeito no Brasil. São eles:

a) A Definição de Atividade Anti-truste

As leis anti-truste nos Estados Unidos, são mais severas do que na maioria dos outros países. Elas entraram em vigor numa época em que a economia dos Estados Unidos representava a metade do total da economia mundial e a estrutura industrial era sinônimo de produção em massa e integração vertical. Esses tempos já se foram, e hoje os pressupostos e os fundamentos para a definição do anti-truste estão sendo repensados. 
b) Práticas e Leis de Responsabilidade sobre o Produto

Como já sabemos muito bem, as práticas de responsabilidade sobre o produto podem impor uma carga de risco grande o bastante às empresas, a ponto de inibir o desenvolvimento ou o marketing de novos produtos, ainda que esses produtos possam trazer algum tipo de benefício. O fato de o produto ser o único fator para o estabelecimento de relações gerou um atmosfera em que o cliente é freqüentemente considerado a vítima, e o fabricante, o carrasco. Isto se aplica principalmente nos Estados Unidos, onde o sistema jurídico, no seu desejo de garantir o acesso a todos, permite danos legais muito maiores que os causados em outros países. Os custos do seguro sobre responsabilidade nos Estados Unidos são 15 vezes maiores que no Japão, e 20 vezes maiores que na Europa. O General Accounting Office (Secretaria Geral de Finanças) em Washington mostra que mais da metade das indenizações determinadas em tribunal, nos casos de responsabilidade, vai para os advogados. Não só os custos do seguro sobre a responsabilidade nos Estados Unidos são maiores do que em qualquer outro país, mas os fabricantes nos Estados Unidos têm de enfrentar 50 conjuntos diferentes de normas e procedimentos referentes a essas questões (NMCS Focus, Dez. 1993). Empecilhos como esses fizeram com que o mercado norteamericano fosse excluído de uma série de processos e produtos existentes em outros países. É necessário estabelecer-se um melhor equilíbrio para que a defesa do consumidor seja adequada e que ao mesmo tempo não iniba o desenvolvimento e o marketing de novas soluções de produtos de grande utilidade.

\section{c) Legislação Tributária}

Normalmente, a legislação tributária não reconhece que as ofertas de produtos mudam com rapidez e que os produtos são constantemente atualizados. O efeito disso é que a amortização lenta e outras disposições da lei inibem com frequiência o investimento em instalações mais produtivas. 
A legislação tributária de diversos países interpreta a pesquisa e o desenvolvimento na perspectiva do modelo de produção em massa, ou seja, como um investimento empregado para a fabricação de um produto, semelhante, do ponto de vista conceitual, ao investimento em um processo dedicado de produção. $\mathrm{Na}$ era do dinamismo, a pesquisa e o desenvolvimento fazem parte do sobrecusto geral necessário à manutenção da capacidade global da empresa.

d) Acordos Comerciais e Definições de Áreas de Comércio

Acordos comerciais e definições de áreas de comércio em geral pressupõem de maneira velada, a estrutura e os conceitos do modelo de produção em massa, e não do sistema de concorrência dinâmica que se encontra em desenvolvimento e de organizações virtuais mundiais. Entre os exemplos de desajustes entre os conceitos legais e a realidade da concorrência dinâmica estão a referência que se faz na lei, à porcentagem sobre acessórios ao produto em território nacional, que despreza o conteúdo informativo do produto, e entende que produto e serviço são itens separados.

Enquanto o sistema jurídico não compreender o novo ambiente de concorrência e solucionar as questões a que nos referimos acima, bem como outras questões, elas representarão um obstáculo ao dinamismo

e) A Dicotomia Artificial entre Produto e Serviço

Os conceitos do modelo de produção em massa estabelecem uma distinção entre produtos e serviços. Em se falando de produtos dinâmicos, serviço, informações e produto físico constituem partes inseparáveis das mercadorias que chegam ao cliente. A dicotomia entre produto e serviço, válida para a época da produção em massa voltada inteiramente para o produto e governada pelo fabricante, é atualmente uma barreira à evolução do dinamismo. 
Muitas pessoas estabelecem uma distinção entre produtos oriundos do trabalho voltados para produto e serviço e produtos oriundos do trabalho voltados para o serviço. Tais percepções se refletem em leis e regulamentações que regem as relações entre parceiros comerciais, empresas e funcionários. A legislação tributária de muitos estados e países, acordos comerciais internacionais e regulamentações sindicais impõem normas diferentes a produtos e serviços. Como resultado, os fornecedores desses artigos distorcem o que fornecem, planejando os métodos de embalagens e distribuição, de modo a tirar vantagem das regulamentações. Em todo o mundo, muitos advogados da área tributária e outros profissionais envidam esforços consideráveis para desvendar os aspectos mais intrincados dessas leis. Considerar produtos, serviços e informações como itens separados está se tornando praticamente artificial.

Muitas pessoas vêm trabalhando arduamente na negociação de acordos de comércio internacional com base em produtos, serviços e com a tributação correspondente. A realidade do mercado está negando o pressuposto que elas adotaram ao fixar essas bases - de que um produto é diferente e pode se distinguir de um serviço.

f) Exigências Estáticas e Intransigentes dos Órgãos Públicos

As características dos sistema de produção em massa - orientado ao preço e ao produto, controlado pelo fabricante, marcado pela passividade do consumidor - refletem-se nos procedimentos dos órgãos públicos em relação ao ciclo de compra. Grandes somas de dinheiro público são envolvidas quando cidades, estado, forças armadas, hospitais e órgãos semelhantes negociam alguma compra. 
No esforço de assegurar a legalidade nos processos de compra, impõem-se instruções detalhadas ao processo de definição, de exigências, licitação e aquisição dos itens. Esse processo, imposto por lei, por vezes leva muitos anos, tanto tempo, que se pode garantir que os artigos adquiridos não serão os mais atualizados à disposição no mercado. Além disso, tal processo não permite que haja uma interação objetiva entre o comprador e o vendedor, tampouco que o comprador exerça qualquer influência sobre o processo de projeto e fabricação do produto. Essas circunstâncias dificultam uma mudança mais rápida rumo ao dinamismo em função da concorrência internacional, uma vez que um enorme mercado interno insiste nos métodos ultrapassados da produção em massa. Nos Estados Unidos, muitas empresas fornecem tanto para o Departamento de Defesa como para iniciativa privada vêem-se andando em "locomotivas" diferentes - um "trem - bala" para a iniciativa privada e uma "maria - fumaça" para o órgão da defesa.

\section{g) Falta de Acesso a Informações}

O acesso a informações é essencial para tornar-se um participante no jogo da concorrência dinâmica. Existe um número de informações inexploradas em todo o mundo. Alguns aspectos das informações são confidenciais, mantidos em segredo por meio de leis ou acordos entre pessoas e organizações, mas, mesmo excluindo-se os dados confidenciais, uma quantidade muito maior de informações poderia ser bem aproveitada.

Muitas pessoas e organizações não percebem a importância das informações disponíveis e não instalam sistema destinados à sua obtenção e utilização. Essa é mais uma barreira à evolução do dinamismo. Numa concorrência que está para se tornar mais dinâmica, os que reconhecem a oportunidade de mudança para ir além da venda de produtos predefinidos, passando a tirar proveito das oportunidades de negócio no acesso, no uso e na venda de serviços por meio de informações, estão no caminho certo. 
h) Estrutura de Pensamento com Base na Rivalidade

A tendência no sentido de se estabelecer relações de rivalidade foi muito fortalecida por um século de relações voltadas inteiramente para o produto e controladas pelo fabricante. Quando o único parâmetro de concorrência se restringe ao preço do produto, as relações são unidimensionais. Compreender como funciona a concorrência é simples: oferecer mais produtos por um preço inferior. Uma relação unidimensional como essa pode ampliar as tendências à rivalidade.

A concorrência dinâmica é multidimensional, envolvendo não apenas o produto, mas serviço, relações de longa duração com os clientes, e capacidade múltipla e rápida de articulação entre os fornecedores. A estrutura de pensamento com base na rivalidade, comumente encontrada na economia de produção em massa, representa uma barreira à identificação de oportunidades de negócios dinâmicas e lucrativas.

\subsubsection{A confiança e o informalismo como princípios}

As novas exigências introduzidas com a concorrência dinâmica, especialmente a necessidade de superação do pensamento calcado na rivalidade bem como a necessidade de uma rápida articulação com fornecedores, segundo GOLDMAN et al. (1995). Disso resulta ser indispensável uma "cooperação pró-ativa, que significa uma empresa participar de uma cooperação tomando decisões com base nas suas prioridades, mas levando em consideração os demais parceiros"(BREMER et al., 1999). Desta forma, uma empresa cria uma cultura propícia para cooperações baseadas na confiança. 
No ambiente de uma $\mathrm{OV}$ ou EV, o relacionamento que se estabelece não dá espaço para deslealdade, um empresário não vê no outro um rival mas um aliado de longo prazo, com o qual poderá e deverá contar sempre que suas competências complementares forem requisitadas. Nessa pressuposição, forçosamente ganha relevo a confiança. É basico e fundamental que os parceiros confiem uns nos outros. Muito embora esse aspecto não seja suficiente, de forma isolada, para garantir o bom desenvolvimento da cooperação, torna-se requisito indispensável.

Além desse aspecto, exclusivamente subjetivo, e que vai animar os empreendedores a continuarem unidos em torno da idéia de cooperação, um aparato obrigacional mais efetivo e mais detalhado far-se-á igualmente indispensável, porquanto a confiança não possa erigir-se em infra-estrutura suficiente para garantir segurança e estabilidade.

A existência desse aparato, que para fins do presente trabalho constitui seu principal objeto, não implica necessariamente que o relacionamento no âmbito das cooperações virtuais sejam emperradas e morosas em função de excesso de documentos, atas, protocolos, relatórios, pedidos etc. A própria idéia de virtualismo estampada por DAVIDOW \& MALONE(1993), significando que todos os atributos de um objeto estão presentes, exceto o objeto em si, implica na prevalência de resultados e conteúdos sobre às formas. Assim, tudo aquilo que for dispensável, sem prejuízo da segurança e estabilidade, deverá ser sacrificado. Ser informal, nesse passo significa ser objetivo e essencial, como se informalismo e confiança fossem as duas faces de uma mesma moeda. 


\subsection{Sistema Jurídico}

\subsubsection{O Sistema Jurídico Romano-germânico}

Conquanto não seja objeto do presente trabalho o comparativismo jurídico, é fundamental, para melhor compreender o fenômeno das Organizações Virtuais, estabelecer um paralelo entre os sistemas romano-germânico(Civil Law) e o Common Law, especialmente tendo em conta que os principais textos sobre aquele fenômeno foram ambientados na Inglaterra e nos Estados Unidos, países que integram respectivamente o Common Law e o Common Law Misto. Nesse sentido, as infra-estruturas reclamadas e as barreiras jurídicas apontadas vão variar tanto no que diz respeito à sua extensão, quanto no que se refere aos mecanismos de superação.

O Direito Comparado, como ciência de comparação dos sistemas jurídicos, agrupou estes em grandes famílias, que tem variado segundo os autores em função dos critérios adotados para a divisão dos mesmos.

Uma classificação útil é a proposta por DAVID (1978), que reuniu os subsistemas de direitos nacionais, nos seguintes sistemas ou famílias:

1) o sistema romano-germânico, que os autores do sistema da common law denominam civil law, no qual se encontra o Direito brasileiro;

2) o sistema da Common Law, que não se confunde com o "sistema inglês"(porque se aplica a vários países, embora nascido na Inglaterra), nem com "britânico"(adjetivo relativo a Grã-Bretanha, entidade política que inclui a Escócia, que pertence ao sistema da família romano-germânica), nem com “anglo-saxão”(porque esse adjetivo designa o sistema dos direitos que regiam as tribos, antes da conquista normanda da Inglaterra, portanto, anterior à criação da common law naquele país); 
3) o sistema dos direitos socialistas, que compunham a denominada Europa do Leste, capitaneados pela extinta URSS;

4) outras concepções da ordem social e do direito, tais como o direito muçulmano, indiano, direitos do Extremo Oriente, direito judaico, direitos da África e de Madagascar, de forte componente ligado à religião, que em determinados países é a principal fonte das normas jurídicas nacionais(Irã, Iraque) e em outros, relevantes para determinados ramos do direito privado, em particular em matéria de família, sendo os demais campos ora da família romano-germânica(Israel e Líbano), ora da common law(Índia e Paquistão).

A estrutura atual dos vários subsistemas que se inserem na família do Direito romanogermânico, se deve à compilação e codificação do Direito Romano, que cristalizou, em textos harmônicos, normas costumeiras, normas escritas esparsas, decisões jurisprudenciais e doutrinárias, juntamente com a obra dos glosadores que, aos poucos, foram, em particular nas universidades medievais(que vicejavam à sombra dos mosteiros e conventos, portanto bem próximas dos cultores do Direito Canônico, na época, escrito e extremamente bem elaborado), dando uma feição racional à soluções casuísticas e assistemáticas dos jurisconsultos romanos. Na sua gênese nota-se uma preocupação com uma ordem racional de conceitos, aparecendo o direito como um sistema: um conjunto de preceitos que deveriam estar agrupados, tal qual um organismo vivo, uma criatura conceitual perfeita, um modelo de justiça racional a ser atingido, a estrutura basilar de uma sociedade ideal, à qual a sociedade real e existente deveria ser conduzida.

Em tal universo geométrico, a dedução, também denominada silogismo, foi o método exegético empregado, copiando dos estudos universitários medievais o rigor lógico de sua apresentação formal, até mesmo com o exagero de se dizer que a verdade é aquela que formalmente se conclui ou se infere por um raciocínio bem construído de acordo com a Lógica Menor. Na aplicação da norma jurídica havia a preocupação de armarem-se silogismos, com suas duas premissas, sendo uma universal(a lei) e outra particular(o fato), 
seguindo-se, automaticamente, a conclusão. Esses caminhos lógicos denominados Lógica Menor, consistiram em desenvolver as teorias aristotélicas sobre o conhecimento científico, até os limites lógicos possíveis e imagináveis.

$\mathrm{O}$ apego às generalidades racionais que o conjunto normativo representa e a certeza da existência do conteúdo da norma que o direito escrito proporciona, fizeram com que a "glosa judiciária" ou jurisprudência(conjunto de decisões reiteradas) fosse afastada em favor da 'glosa erudita" ou doutrina, e que o costume geral cedesse lugar à lei escrita, sempre que possível reunida em conjuntos harmônicos e racionais: os códigos.

O pensador que melhor caracteriza o sistema romano-germânico é Hans Kelsen, com sua Teoria pura do direito: o direito é uma construção escalonada(Stufenbau), tão racional e geométrica que, por isso mesmo, tem a forma de uma pirâmide, no ápice da qual se encontra uma norma fundamental(Grundnorm), a partir da qual as normas menos gerais retiram sua eficácia e vão perdendo sua generalidade, até aquelas normas colocadas na base(os contratos e sentenças) em que o princípio geral guarda sua eficácia após percorrer outros campos de particularismos crescentes(a constituição, a lei ordinária, o artigo...). O culto desmesurado da lógica formal a que este sistema remete, e a racionalidade da construção dedutiva, tida como válida por seu próprio rigor aquitetural, levam a um certo desprezo pelos resultados na vida corrente. De tal sorte que mudanças na vida social só receberão tratamento adequado nas soluções de conflitos, quando a legislação tiver incorporado tais mudanças. 


\subsubsection{O Sistema Jurídico da Common Law}

Na common law a idéia que permeia o sistema é de que o direito existe não para ser um edifício lógico e sistemático, mas para resolver questões concretas. Antes de examinar se existe ou não algum geometrismo no sistema, este se preocupa como os remédios: reliefs and remedies. Nesse quadro, a doutrina abstrata tem papel secundário em favor de soluções pragmáticas. Na Inglaterra, o papel da Universidade sempre foi insignificante na formação do direito ou na formulação de teorias generalizantes. Os estudos de Filosofia do Direito, tanto na Inglaterra quanto nos EUA, se denominam jurisprudence, ou seja abstrações a partir de casos julgados.

"Inútil buscar uma figura geométrica, pelo menos na geometria cartesiana, que permita descrever a common law. Mais se assemelharia a uma colcha de retalhos que cumpre o seu papel de dar abrigo à sociedade e pensar os seus ferimentos, representados em violações da paz social"(SOARES,1999).

Para resumir o contraste entre os dois sistemas vale transcrever o seguinte trecho de DAVID (1978):

"Nos países de direito escrito em que o direito se apresenta principalmente sob a forma dum direito legislativo, as regras de direito são formuladas com uma tal generalidade , que o apelo à razão se processa, normalmente, no quadro das fórmulas gerais, sob a forma de aplicação e interpretação destas regras; a existência de lacunas na ordem legislativa é dificilmente reconhecida; mais do que para completar a ordem jurídica, a razão desempenha uma função na interpretação da lei. Num sistema jurisprudencial, como é o sistema inglês, a 
situação apresenta-se muito diferente. $\mathrm{O}$ aspecto casuístico que então reveste o direito, deixa subsistir, de forma muitas vezes intencional, muitas lacunas; e a razão é francamente reconhecida como uma fonte subsidiária do direito, chamada a preencher estas lacunas. A uma técnica de interpretação do direito, substitui-se uma técnica distinções, visando a estabelecer regras novas, cada vez mais precisas, em vez de aplicar uma regra preexistente. Os sistema de direito da família romano-germânica são sistemas fechados, a common law é um sistema aberto, onde novas regras são continuamente reveladas; estas novas regras fundam-se na razão".

Dentro ainda do sistema da common law é observável, em oposição ao direito criado pelo juiz(judge-made law), o direito criado pelo legislador postado fora do Pode Judiciário(Statute law), resultante dos enactments of legislature(tratados internacionais, constituição federal, constituições estaduais, leis ordinárias federais e estaduais, regulamentos administrativos etc.).

Nesse aspecto particular reside a fundamental diferença entre o sistema americano e o inglês. No primeiro, reconhece-se a primazia dos statutes em relação aos case law, de tal sorte que pode ser modificado pela lei escrita, dizendo-se então que o case foi reversed by statute. Esse mecanismo faz com que o sistema americano seja considerado um sistema misto. O sistema inglês, que era considerado common law puro antes da revolução industrial, sofreu algumas alterações em função da evolução das leis trabalhistas, mas ainda permanece como modelo mais puro, desconhece a primazia de uma constituição escrita e que se coloca numa estrutura piramidal.

Seja qual for a variante do sistema da common law, o ponto fulcral é a regra de precedentes, onde há verdadeira criação de normas através do julgamento de casos concretos, chamados holdings, que é tudo aquilo que foi discutido e argüido perante o juiz e para cuja solução foi necessário "fazer" a norma jurídica. 
Essa característica de sistema aberto explica, de certa forma, o detalhismo existente nas Leis(Statutes) bem como nos contratos civis e comerciais que nada mais refletem senão o casuísmo do sistema. Assim, como a lei não é o centro do sistema, e na sua lacuna há sempre que prevalecer o precedente, os contratos são redigidos com todos os pormenores e hipóteses imagináveis, contribuindo indiretamente com a inovação do direito.

\subsubsection{A Ética e o Direito}

Tão importante quanto distinguir os sistemas jurídicos existentes no planeta, com vistas à adequação das infra-estruturas exigidas pelas O. V. e E. V., é estabelecer a distinção entre Ética e Direito, já que em algumas experiências práticas, tem-se noticiado a existência de um "código de ética", talvez equivocadamente com única infra-estrutura legal existente.

Segundo VÁZQUEZ apud NALINI(1999), ética é a ciência do comportamento moral dos homens em sociedade. É uma ciência, pois tem objeto próprio, leis próprias e método próprio. O objeto da ética é a moral. A moral é um dos aspectos do comportamento humano. A expressão deriva da palavra romana mores, com o sentido de costumes, conjunto de normas adquiridas pelo hábito reiterado de sua prática. A ética é uma disciplina normativa, não por criar normas, mas por descobri-las e elucidá-las.

Todas as ciências humanas se relacionam intimamente com a Ética, pois o comportamento moral não é outra coisa senão uma forma específica do comportamento do homem, que se manifesta em diversos planos: psicológico, social, prático-utilitário, jurídico, religioso ou estético.

Dentre as formas de comportamento humano, a jurídica é a que mais intimidade guarda com a moral. Nesse sentido, aproximam o direito da moral os seguintes elementos:

${ }^{1}$ ADOLFO SÁNCHEZ VÁSQUEZ. Ética -15ª ed. Rio de Janeiro: Civilização Brasileira,1995. 
a) Direito e moral disciplinam a relação entre os homens por meio de normas. Impõem conduta obrigatória a seus destinatários.

b) Tanto as normas jurídicas quanto as morais se apresentam sob forma imperativa, não constituindo mera recomendação.

c) Ambas são preordenadas à garantia da coesão social, atendendo à mesma necessidade social.

d) Moral e direito se modificam no momento em que se altera historicamente o conteúdo de sua função social. São formas históricas de comportamento humano.

Em vários aspectos entretanto, moral e direito se distanciam:

a) A vida moral é interior, a vida jurídica é exterior. A observância da norma moral depende do foro íntimo da consciência individual. No momento em que o agente moral interioriza o preceito ele o cumpre. Já a observância da jurídica independe da consciência. Mesmo sem se convencer do acerto dela, sem aderir intimamente ao seu conteúdo, o agente poderá cumpri-la. Em outras palavras, segundo MÁYNES² apud NALINI (1999)“ a legalidade de um proceder consiste na mera adequação externa do ato à regra; sua moralidade, na concordância interna”. O ato moral postula discernimento, para assim ser considerado. $\mathrm{O}$ ato jurídico pode ser praticado inconscientemente e não perderá esse atributo.

b) A coação é interna em ralação à moral e externa no tangente ao direito. $\mathrm{O}$ descumprimento de preceito moral pode ensejar reação da consciência - o remorso- ou uma reação tênue do grupo - a reprovação social. Ambos podem não constranger o agente. Já a inobservância da regra jurídica impõe consequiências exteriores: a prisão na esfera penal, a repercussão patrimonial no cível ou a substituição da vontade do agente pela vontade do

${ }^{2}$ EDUARDO GARCÍA MÁYNES, Ética - Ética empírica. Ética de bens. Ética formal Ética valorativa, 18 ed. ,México: Editorial Porrua, 1970, p. 167. 
Estado, que em nome dele pratica o ato a que se recusou. Existe uma sanção concreta em relação à norma jurídica e uma sanção virtual em relação à moral.

c) A moral é mais abrangente que o direito, ela interfere num domínio muito ampliado das relações humanas, dentro da família, da vizinhança, nos vínculos de solidariedade ou de amizade e no exercício da cidadania. Nesse ambiente nem todas as regras mereceram a preocupação do legislador ou dos magistrados, de tal forma que nem tudo o que é moral é jurídico. De outra parte, quase tudo o que é jurídico tem algum substrato moral.

d) A moral é anterior ao direito. O direito é manifestação de um estágio aprimorado de convivência.

e) Na expressão de NALINI (1999), “as sociedades divididas não dispõem de mais de um direito, pois positivação da vontade dominante, do monopólio legítimo da força. Podem cultivar, porém, várias morais, coincidentes ou não com a moral oficial”.

f) Ainda segundo NALINI (1998), “ à proporção que os homens observam as regras fundamentais de convivência de maneira espontânea, tornando despicienda a coação, ampliase a esfera da moral. E critério de aferição do progresso moral é, exatamente, a ampliação da esfera da moral, com a conseqüente redução da esfera do direito".

Entendida a Ética como ciência que estuda o comportamento moral da sociedade, torna-se evidente que o sentido empregado na denominação da infra-estrutura, só pode significar código com regras morais erigidas à condição de direito, ou seja contrato.

Não poderia ser diferente, uma vez que no ambiente de relações comerciais, por mais evoluído que seja um povo e por maior que seja o seu progresso moral, não faria o menor sentido considerar um código de ética como infra-estrutura jurídica ou legal, numa tradução imperfeita do termo em inglês. O simples remorso, ou ainda a reprovação do grupo ante a transgressão de um preceito, são insuficientes para garantir a estabilidade da dita "infraestrutura". 
Disso resulta que, por mais que o conteúdo das regras se assemelhem a preceitos morais, eles acabam por se exteriorizar através do direito, no seu nível de produção mais próximo aos indivíduos, qual seja um contrato privado.

\subsubsection{A Lei como superestrutura}

Nos países que integram a família do sistema jurídico romano-germânico, e em certa medida naqueles que se inserem na categoria de common-law misto, leia-se Estados Unidos, o direito produzido pelo legislador postado fora do Poder Judiciário, assim considerados os tratados internacionais, a constituição federal, as leis ordinárias federais, as constituições estaduais, as leis ordinárias estaduais e municipais, os regulamentos locais, apresentam-se como fontes hierarquicamente superiores. A Lei lato senso, que compreende toda essa gama de normas escritas, no exato momento da solução dos litígios deve ser analisada em primeiro lugar. O hermeneuta ao deparar-se com o caso concreto deverá proceder a uma análise que vai deste a norma escrita superior, no nosso caso a Constituição, até aquelas de nível municipal de caráter regulamentar, a fim não apenas identificar qual o preceito que se amolda aos fatos, mas principalmente verificar se não há contradições entre normas inferiores e superiores.

Esse proceder, próprio do sistema romano-germânico que atende a um rigorismo cartesiano já descrito linhas atrás, revela e reforça o primado da Lei escrita. O tempero desse rigor fica por conta do Poder Judiciário, que interpretar a Lei diante do caso concreto, vai trazê-la mais próximo da realidade social e cultural do momento, sem que isso signifique, entretanto, a vinculação para decisões futuras, como ocorre nos sistemas que integram a família do common-law. Num ambiente assim, é dado aos particulares agirem com liberdade 
tendo a Lei como limite. Ou seja, é lícito fazer tudo aquilo que a Lei não proíbe. Invertendose tal principio tem-se, com relação ao próprio Estado e seus agentes públicos, que a eles é dado fazer exatamente o que a Lei manda.

Os contratos, que são uma espécie de negócio jurídico, cuja essência é a autoregulamentação dos interesses particulares, são reconhecidos pela ordem jurídica que lhe dá força criativa. Como assinala DINIZ (1996) o contrato repousa na idéia de um pressuposto de fato querido pelos contraentes e reconhecido pela norma jurídica como base do efeito jurídico perseguido. Seu fundamento é a vontade humana, desde que atue conforme à ordem jurídica. Seu habitat é o ordenamento jurídico. Ainda na ótica da mesma autora, "a norma jurídica negocialmente criada, que não estatui sanção, mas um comportamento cuja conduta oposta é o pressuposto da sanção imposta pela norma jurídica geral, não é norma jurídica autônoma. Ela somente será jurídica em combinação com normas gerais estatuidoras de sanções"(DINIZ, 1996).

Conforme demonstrado, a Lei em seu sentido amplo funciona como fator condicionante da eficácia dos negócios jurídicos e encontra-se além da vontade dos particulares. Em nosso sistema existem, além das inúmeras leis esparsas disciplinando contratos típicos, Códigos como o Cívil(CC), Comercial(CCo) e de Processo Civil(CPC), fixando regras de caráter geral, que afetam e condicionam a validade dos negócios jurídicos.

Afigura-se fundamental realçar o papel da Lei no nosso sistema jurídico, especialmente tendo em conta o fato de que no momento da elaboração dos contratos, vários aspectos já estarão previamente condicionados por força da Lei, tornando-se indispensável, muitas vezes, a acréscimo de regras. Diferentemente do que ocorre nos contratos celebrados em outros sistemas, como o da common-law, onde o vazio legislativo e os parâmetros da judge made Law impõem a redação de extensas clausulas que contemplem as hipóteses mais remotas, não deixando qualquer espaço para aplicação dos precedents. 


\subsubsection{O contrato como fonte de obrigações e infra-estrutura}

Vários autores se reportam à necessidade de fixação de mecanismos de coordenação, ora denominando de infra-estrutura legal, ou mais adequadamente traduzido para o português como infra-estrutura jurídica, ora se reportando simplesmente a um contrato. Com efeito, segundo CAMARINHA-MATOS e LIMA (1999), um contrato deve estabelecer as condições de interdependência / cooperação entre parceiros e, consequentemente, pode ser a base para uma política de coordenação.

Nesse sentido, e ainda para os mesmos autores, um sistema de coordenação para EV poderia ser baseado - nos seus níveis mais elevados - em cláusulas inseridas no próprio contrato de negócio ou nos vários contratos que envolvem o mesmo negócio. Os autores chegam até a formular um exemplo em que duas partes se comprometeriam a remeter um ao outro, em determinado dia, um relatório com o status da produção, referente a algum processo de negócio a eles distribuído, definindo-se desta forma dois planos de trabalho, um para cada parte, de tal forma que cada relatório conteria as atividades a serem desenvolvidas pelo outro, dando vida e regulamentação àquela cláusula contratual. Propõem assim, uma forma de extensão do para os sistemas PPC/ ERP, de forma que o sistema de gerenciamento ficasse amparado por um contrato baseado no fluxo de trabalho.

Mais importante do que a sugestão, é o reconhecimento de que novas formas de cooperação demandam novas formas de contratos. Mesmo para as transações comerciais clássicas, não existe uma forma padrão de contrato, cada empresa tem seu próprio modelo de contrato. Para as mais complexas e incertas formas de relacionamento como as emergentes dos cenários de empresas virtuais, existe a necessidade de se experimentar e determinar novas formas de contratos. 


\section{O contrato como fonte de obrigações}

Sendo as obrigações relações jurídicas, de caráter patrimonial, mediante as quais uma pessoa que tem o nome de devedor, assume o dever de dar, fazer ou não fazer alguma coisa em favor de outrem, denominado credor para que existam necessárias se tornam causas originárias, de que as obrigações são consequiências. A essas causas dá-se, em geral, o nome de fontes da obrigação. E dentre elas se destaca, por ser a mais comum, o contrato.

\section{Conceito de contrato}

Segundo CLÓVIS BEVILÁQUA (1956), entende-se por contrato o acordo de vontade de duas ou mais pessoas com a finalidade de adquirir, resguardar, modificar ou extinguir direito. Esse conceito é baseado no art. 81 do Código Civil, que define o ato jurídico como sendo "todo ato lícito que tenha por fim imediato adquirir, resguardar, transferir, modificar ou extinguir direitos". Tal definição, entretanto tem recebido críticas, em virtude do excessivo subjetivismo de que se reveste. Segundo ela, o mero acordo de vontades seria o bastante para criar o contrato, que desse modo quase se confundia com o consentimento ou com o simples negócio jurídico bilateral.

Por tal razão, atentou-se para a finalidade do contrato e já hoje há uma forte corrente doutrinária que o entende como o acordo de vontades de duas ou mais pessoas que tem por finalidade constituir, regular ou extinguir uma relação jurídico - patrimonial. Essa a orientação seguida pelo Código Civil italiano de 1942, cujo art. 1.321 (Livro IV, Título II, Capítulo I) define o contrato como sendo "o acordo de duas ou mais partes para constituir, regular ou extinguir entre si uma relação jurídico - patrimonial'. Esse novo conceito do Código Civil italiano modificou o que dispunha o art. 1.098 do Código Civil de 1865, revogado, que definia o contrato como "acordo de duas ou mais pessoas para constituir, regular ou extinguir entre si um vínculo jurídico”.

Em tais condições, melhor atualmente se conceitua o contrato como "o acordo de duas ou mais pessoas para, entre si, constituir, regular ou extinguir uma relação jurídica de natureza patrimonial". 
Seguindo a dicotomia do nosso Direito Privado, os contratos poderão ser civis ou comerciais. Aparentemente, entretanto, muitas vezes os contratos civis se confundem com os comerciais. O próprio Código Comercial, confundindo contrato com obrigação, dá essa impressão quando dispõe, no art. 121, que "as regras e disposições do Direito Civil para os contratos em geral são aplicáveis aos contratos comerciais, com as modificações e restrições estabelecidas neste código". Parece, assim, que apenas como exceção serão aplicadas normas peculiares aos contratos comerciais, no mais vigorando as regras do Direito Civil.

Enquanto a prova, no Direito Civil, é feita segundo princípios rígidos, no Direito Comercial ela é admitida com maior flexibilidade e rapidez, amparada sempre na boa - fé dos contratantes. Tudo isso, naturalmente, decorre da natureza progressiva do Direito Comercial, em face do desenvolvimento do comércio e da crescente rapidez com que este se faz. Sendo o Direito Comercial um direito em perene transformação, ligado essencialmente às contingências econômicas, políticas e sociais do mundo, os contratos mercantis necessariamente têm que se adaptar a essa variabilidade, muitas vezes sendo forçados a fugir às regras formais do Direito Civil.

\section{Forma dos contratos comerciais}

Algumas vezes, para a sua validade, estabelece a lei que os contratos devem revestirse de formas especiais. O Código Civil, referindo-se aos atos jurídicos em geral, estatuiu (art.130) que "não vale o ato que deixar de revestir a forma especial determinada em lei", regra essa assentada no art. 82 , que, de modo amplo, estabelece que "a validade do ato jurídico requer agente capaz, objeto lícito e forma prescrita ou não defesa em lei”. Caso o ato, para que a lei determinou forma especial, não se revista dessa forma, será considerado nulo, nos termos do art. 145, n. $^{\circ}$ III, do Código Civil.

Também para alguns contratos comerciais a lei determina formas solenes, que deverão ser observadas a fim de que possam ter validade. O art. 142 do Código Comercial preceitua que: 
“Aqueles contratos para os quais neste código se estabelecem formas e solenidades particulares não produzirão ação em juízo comercial se as mesmas formas e solenidades não tiverem sido observadas."

Haverá, desse modo, liberdade de forma, desde que a lei não determine expressamente a forma solene para a validade do contrato. É o que, com mais clareza, diz o art. 129 do Código Civil, ao estabelecer que:

"A validade das declarações da vontade não dependerá de forma especial, senão quando a lei expressamente a exigir."

Como atos que requerem forma especial estão as sociedades comerciais, exigindo o Código (art.300) que a constituição delas seja sempre feita por escritura pública ou instrumento particular; e o art. 302 estabelece as cláusulas obrigatórias e outras meramente facultativas.

A obrigatoriedade dos contratos para que são exigidas formas especiais só se torna efetiva quando essa forma é observada. Assim, o Código Comercial, traçando a regra geral de que os contratos mercantis se tornam obrigatórios, desde que as partes troquem o mútuo consentimento, especificou que, quando a forma escrita é necessária, essa obrigatoriedade só se efetiva ao ser o contrato reduzido a escrito. Esse princípio da lei comercial está em perfeita consonância com aquele citado no art. 129 do Código Civil, que estipulou taxativamente que:

“A validade das declarações de vontade não dependerá da forma especial, sendo quando a lei expressamente a exigir".

$\mathrm{Na}$ interpretação das cláusulas dos contratos deve ser dada maior importância à intenção das partes do que à rigorosa e restrita significação das palavras. Essa regra, contida no art. 131, $\mathrm{n}^{\circ}$ 1, do Código Comercial, foi reforçada pelo art. 85 do Código Civil, que dispõe que: 
Quer a lei, desse modo, resguardar a boa - fé das partes contratantes, princípio de largo alcance no campo de Direito Comercial, pois a boa - fé, característica das operações mercantis, serve para dar maior rapidez e segurança aos atos de comércio.

O momento da formação o contrato. Contratos por correspondência - Sendo o contrato uma das principais fontes das obrigações, necessário será saber qual o momento exato em que se forma. $\mathrm{O}$ assunto tem particular interesse no Direito Comercial, pois nesse, os contratos são, em regra, bilaterais, isto é, criam obrigações para ambas as partes e, igualmente onerosos, dado o caráter eminentemente especulativo da atividade comercial. Em tais circunstâncias, se bem que já se sabia até quando o proponente está obrigado a cumprir a sua oferta e que o aceitante também fica obrigado com a aceitação, necessário será determinar qual o momento exato em que o contrato se forma, vinculando as partes e gerando obrigações em virtude da troca de consentimentos.

Nos contratos entre presentes não há dúvidas a respeito: só valendo a proposta se a aceitação for feita imediatamente, o momento da formação do contrato é aquele em que a pessoa a quem a proposta é dirigida manifesta a sua vontade. Essa manifestação é, como diz a lei, imediata e não simultânea; isso significa que há, de qualquer modo, um espaço de tempo a mediar entre a proposta e a aceitação - mas espaço de tempo tão insignificante, tão diminuto que alguns autores consideram o contrato entre presentes como aquele em que há declarações simultâneas por parte dos contratantes, o que não é verdadeiro.

Nos contratos entre ausentes o assunto se torna mais delicado. A lei, para melhor distinguir esses contratos, considera-os como os que são feitos por correspondência epistolar ou telegráfica (Código Civil, art. 1.086; Código Comercial, art.172). Isso, evidentemente, não deve ser entendido literalmente, pois podem existir contratos entre ausentes não apenas formulados por meio de correspondência epistolar, telegráfica ou radiotelegráfica como, igualmente, por meio de "sinais semafóricos, aparelhos automáticos, núncios (mensageiros) e intermediários". 
Muito comuns, entretanto, na vida comercial, é a formação dos contratos por correspondência epistolar, telegráfica ou radiotelegráfica. Partindo a iniciativa do contrato do proponente e sendo a aceitação dada por escrito, procura-se saber o momento em que vínculo contratual se forma, pois a fixação desse momento terá sérias consequiências para ambos os contratantes.

Várias teorias foram formuladas para determinar o momento em que se aperfeiçoa o contrato por correspondência. Dentre essas, as mais destacadas são as denominadas da cognição ou informação e da declaração ou agnição, esta subdividida em três correntes diversas, um intitulada agnição pura e simples, a segunda denominada de teoria da recepção e a última chamada de teoria da expedição.

Segundo a teoria da informação ou cognição, o vínculo contratual se forma nos contratos por correspondência no momento em que o proponente toma conhecimento da aceitação. Algumas legislações adotaram essa teoria, mas ela tem sido desprezada em virtude da dificuldade que se tem de saber qual o instante exato em que o proponente toma conhecimento da resposta do aceitante. Pode, por exemplo, a carta que contém a aceitação ou a recusa ficar em poder do proponente durante muito tempo sem que este dela tome conhecimento.

Pela teoria da agnição ou declaração o momento em que o contrato se aperfeiçoa fica subordinado à declaração da vontade da pessoa a quem a proposta é dirigida. Sendo o contrato um acordo de vontades, desde que a pessoa a quem é proposta é dirigida dá seu consentimento, o vínculo contratual está formado, passando a gerar obrigações para as partes. 
Por último, uma terceira corrente reputa como o momento em que o contrato se aperfeiçoa aquele em que a resposta é expedida ao proponente. Tem essa teoria o nome de teoria da expedição. Para ela, não tem valor o momento em que a aceitação é redigida ou em que o proponente recebe ou toma conhecimento da resposta. Basta que a aceitação seja expedida em tempo útil, para que o contrato se considere formado. E o momento exato do nascimento do vínculo contratual é aquele em que a pessoa a quem foi endereçada a proposta expede ao proponente a sua resposta, aceitando-a.

\subsubsection{Personalidade Jurídica}

Dentre as várias modalidades de contratos cabe destacar aqueles em que não há alteridade, ou seja, existência de interesses contrapostos, mas um objetivo comum almejado pelas partes contraentes. Nesses casos, embora não se possa falar em relação débito e crédito, operam da mesma forma no campo obrigacional, definindo um padrão de comportamento entre as partes. Trata-se dos contratos que induzem o surgimento das pessoas jurídicas. "Pessoas jurídicas são entidades a que a lei empresta personalidade, isto é, são seres que atuam na vida jurídica, com personalidade diversa da dos indivíduos que os compõem, capazes de serem sujeitos de direitos e obrigações na ordem civil"(RODRIGUES, 74).

Segundo o autor acima referenciado, a pessoa jurídica surge para suprir a própria deficiência humana. Freqüentemente o homem não encontra em si forças e recursos necessários para uma empresa de maior vulto; de sorte que procura, estabelecendo sociedade com outros homens, constituir um organismo capaz de alcançar o fim almejado. Dentre as várias teorias que buscam explicação para a existência dessas entidades, adotou a legislaçãobrasileira a teoria da realidade objetiva, de procedência germânica, onde a 
vontade pública ou privada é capaz de dar vida a um organismo que passa a ter existência própria, distinta da de seus membros, capaz de tornar-se sujeito de direito, real e verdadeiro. A idéia básica dessa teoria é a de que as pessoas jurídicas, longe de serem mera ficção, são uma realidade sociológica, seres com vida própria, que nascem por imposição das forças sociais. Com efeito , o art. 18 do Código civil determina que começa a existência legal das pessoas jurídicas pela inscrição de seus contratos no registro peculiar; o art. 20 proclama que as pessoas jurídicas têm existência distinta da dos seus membros; e o art. 21 enumera as hipóteses em que termina a existência dos entes morais, pessoas morais, ou simplesmente pessoas jurídicas.

Se a lei declara que a existência no plano do direito se inicia com a inscrição dos estatutos no registro peculiar, é porque, naturalmente, admite que exista no campo material uma organização subjacente, representado por um grupamento de pessoas buscando um fim comum, ou por um patrimônio separado, votado a uma determinada destinação, como ocorre no caso das fundações. Assim, é possível divisar os dois elementos que compõem a idéia de pessoa jurídica: o material, representado por aquela associação de pessoas(preexistente); e o jurídico, constante da atribuição de personalidade, que decorre de uma determinação legal, e cuja eficácia advém da inscrição dos estatutos no registro peculiar. O Estado, ao reconhecer as pessoas jurídicas, reconhece alguma coisa que já preexistia. Se essa coisa já preexistia é evidente que o reconhecimento por parte do Estado não dá nascimento à pessoa jurídica, mas tão somente condição para participar da vida dos negócios.

É importante transcrever nesse passo, o que vem disciplinado no $\S 2^{\circ}$ do art. 20 do Código Civil, que significa reconhecimento dessa precedência por conta da atribuição de alguma consequiência a tal entidade, mesmo antes de seu registro: As sociedades enumeradas no art. 16, que, por falta de autorização ou de registro, se não reputarem pessoas jurídicas, não poderão acionar a seus membros, nem a terceiros; mas estes poderão responsabilizá-las por todos os eus atos. 
As pessoas jurídicas podem ser classificadas tendo em vista sua estrutura ou a órbita de sua atuação(RODRIGUES,74).

Sob o primeiro aspecto é possível agrupá-las em a) as que têm como elemento subjacente as pessoas, tais como associações e sociedades - universitas personarum; b) as que constituem em torno de um patrimônio destinado a um fim, isto é, as fundações universitas bonorum.

Sob o segundo aspecto, as pessoas jurídicas podem se de direito público externo(Estados soberanos, Vaticano, Organizações Internacionais) ou de direito público interno(União, Estados, Municípios, distrito Federal), ou ainda de direito privado. Essas últimas, de acordo com o art. 16 do Código Civil, se subdividem em sociedades civis, associações, fundações e sociedades comerciais. Além destas, cabe acrescer as cooperativas, que embora tenham objeto comercial, inserem-se na disciplina civil por determinação legal.

\subsubsection{Sociedades Civis e Associações}

As sociedades civis são aquelas que se personificam pelo contrato de sociedade, que é a convenção por via da qual duas ou mais pessoas se obrigam a conjugar esforços ou recursos para a consecução de fim comum(C.C. art. 1.363). Tal contrato também se denomina corriqueiramente contrato social. O interesse dos sócios é idêntico; por isso todos, com capitais ou atividades, se unem para lograr uma um finalidade, econômica ou não. 
Segundo MONTEIRO(1978), embora não haja distinção legal entre sociedades civis e associações, "do ponto de vista doutrinário, não se confundem sociedades civis e associações. Nas primeiras, há fito de lucro, enquanto, nas segundas, inexiste finalidade lucrativa. O objeto das associações é puramente cultural, beneficente, altruísta, religioso, esportivo ou moral. Segundo DINIZ(1996), são consideradas de fins não lucrativos as sociedades civis que "tiverem por escopo a satisfação de interesses religiosos(confrarias, irmandades, cabidos), culturais(academias de letras), políticos, científicos, artísticos, recreativos(Associação Brasileira de Clubes Sociais(RT, 489:210), beneficentes(APAE), estudantis(Associação de Pais e Mestres) etc., caso em que se denominarão associações...”

Ainda para a mesma autora associação (Verein) é um contrato pelo qual um certo número de pessoas ao se congregar, coloca, em comum, serviços, atividades, conhecimentos, em prol de um mesmo ideal, objetivando a consecução de um determinado fim não econômico(Idealverein) ou econômico(wirtschsftfliche verein), com ou sem capital, e sem intuitos lucrativos. Poderá ter finalidade: a) altruística(associação beneficente); b) egoística (associação literária); e c) econômica não lucrativa (associação de socorro mútuo).

Outro aspecto diferenciador entre sociedades civis e associações, além da finalidade lucrativa, diz respeito à troca de membros. Nas associações, havendo mutação subjetiva, parcial ou total, de seus componentes, permanecerá a mesma, apesar da completa variação dos associados, tendo-se em vista o acesso aberto e o número ilimitado de membros. Tal não ocorrerá com a sociedade, que, por requerer confiança inter certas personas, apenas excepcionalmente permite que algum sócio seja, p. ex. substituído em razão de morte pelo seu herdeiro. Com a saída de um dos sócios operar-se-á, em certos casos, a dissolução 
parcial da sociedade ou sua continuação sob forma renovada. Cabe lembrar ainda, que nas associações não se faz mister formação de um capital com a colaboração dos sócio. Entretanto, muitas vezes a colaboração ocorre, bem como ocorre a formação de um patrimônio, e a realização de atos negociais para manutenção desse patrimônio ou sua ampliação, não faz com que perca a categoria de associação, desde que não signifique retorno financeiro direto aos associados.

\subsubsection{Fundações e Cooperativas}

Distinguem-se das sociedades civis e associações, mas ainda sob o manto da legislação civil, as fundações e as cooperativas. As primeiras em verdade são organizações que giram em torno de um patrimônio. Trata-se de um patrimônio que se destina a determinada finalidade. A lei, cumpridos certos requisitos, atribui personalidade a esse acervo de bens, ou seja, atribui-lhe a capacidade para ser titular de direitos. Segundo CLOVIS BEVILÁQUA (1956) “fundação é uma universalidade de bens personalizada, em atenção ao fim que lhe dá unidade" ou "é um patrimônio transfigurado pela idéia , que o põe a serviço de um fim determinado". Com efeito, dois elementos se destacam nessas definições: patrimônio e fim.

Para ser criada a fundação, é preciso que seu instituidor faça a dotação de bens livres, especificando o fim a que se destina. A instituição deve ser ultimada por escritura pública ou testamento. Como se vê, diferentemente do que ocorre com as demais pessoas jurídicas, inexiste o concurso de vontades de duas ou mais pessoas, basta o desejo de uma só, com a afetação do patrim6onio doado, que o Estado, verificada a presença dos requisitos exigidos por lei, deferirá personalidade jurídica. 
As cooperativas, por seu turno, embora apresentem as mesmas características das associações, quais sejam a inexistência de fito lucrativo e abertura para ingresso e saída de membros, delas se diferem pela natureza dos negócios que pratica em prol de seus associados e da necessidade de autorização estatal. Constituem sociedades não empresariais(Lei n. $5764 / 71$, arts. $3^{\circ}$ e $4^{\circ}$ ), que prestam serviços aos associados sem objetivo de lucro; não há um processo acumulativo de investimentos e reinvestimentos societários, segundo DINIZ (1996). A sociedade cooperativa poderá constituir-se por deliberação da assembléia geral dos fundadores, por instrumento particular, por escrita pública, pressupondo um número mínimo de vinte associados.

O ato constitutivo é um contrato de sociedade, que se aperfeiçoará com a autorização de funcionamento pelo órgão público competente(art. 17). Uma das funções centrais da cooperativa é a troca direta de bens e serviços com seus cooperados, eliminando intermediários na circulação da riqueza.

Podem ser elencados os seguintes papéis assumidos pelas cooperativas: produção agrícola; produção industrial; de trabalho; de beneficiamento de produtos; de compras em comum; de venda em comum; de consumo; de crédito; de seguros; de construção de casas populares; de editoras; e escolares.

\subsubsection{Sociedades Comerciais}

Distinguem-se as sociedades comerciais das sociedades civis exclusivamente pela prática de atos do comércio, por parte das primeiras, inteiramente inexistente nas segundas. Por atos de comércio entendem-se os negócios jurídicos referentes diretamente ao exercício normal do comércio ou da indústria, consistentes na operação típica de compra e venda, ou ainda naqueles atos que imprimem feição característica ao comércio, ou, na clássica definição, em atos de mediação entre o produtor e o consumidor, com habitualidade e 
finalidade lucrativa, conforme preleciona ALMEIDA (1998a). O que distingue uma sociedade comercial de uma sociedade civil, não é o lucro, mas a modalidade de ato praticado para atingi-lo. Como acentua Clovis Beviláqua, a forma de que se revista não é suficiente para alterar-lhe a natureza. Assim, ainda que estruturada por quotas de responsabilidade limitada, a sociedade civil conserva a sua natureza, aplicando-se-lhes as regras do Direito Civil.

“O fim comercial(Cod. Com. Art. 311), o propósito de comerciar(art. 31), o intuito de negociações ou operações comerciais(arts. 317 e 325), eis o critério que assinala a comercialidade das sociedades", esclarece CARVALHO DE MENDONÇA (1945).

Essa distinção existe porque nossa codificação, de inspiração francesa, reconhece e destaca a atividade comercial para fora da égide das leis civis. Essa peculiaridade remonta ao início da Idade Moderna, em que os comerciantes se sujeitavam a uma jurisdição peculiar.

Seja como for, persistem em nossa legislação traços diferenciadores entre atividade civil e comercial, muito embora não existam critérios lógicos e científicos que os suportem, a não ser a própria lei. Esses traços por vezes encerram prerrogativas, por outras verdadeiros gravames, como a hipótese de falência, instituto típico aplicável aos comerciantes.

As sociedades comerciais, por outras palavras, nada mais são do que formas coletivas do exercício do comércio, legalmente considerado.

\subsubsection{Sociedades de Fato e Irregulares}

Pessoas físicas e jurídicas podem, igualmente, ser sócias de qualquer sociedade, sejam elas civis ou comerciais. As sociedades podem, a despeito de não se encontrarem revestidas das formalidades legais exigidas, ser objeto de preocupação do legislador e estarem aptas a gerar efeitos sobre as pessoas que com elas se relacionem, bem como com seus próprios integrantes. 
Sociedades de fato são aquelas que funcionam exercitando atividades comerciais ou civis, sem , contudo haver-se organizado segundo os dispositivos legais, não arquivando os seus atos constitutivos, se houver, no Registro do Comércio ou de Títulos de Documentos. Alguns autores, em função da existência ou não de um contrato, um regulamento, um estatuto ou um Código de Ética, definem como sociedades irregulares aquelas que, embora não registradas, possuem algum instrumento de natureza obrigacional com aqueles adrede mencionados(COELHO,98).

O que difere basicamente uma da outra, é que o ato constitutivo da sociedade irregular serve como elemento de prova entre os sócios.

Com ou sem documento escrito e assinado, ambas as sociedades, de fato ou irregular, possuem o mesmo conjunto de responsabilidades perante terceiros que com ela contratem. Vale dizer que ações podem ser movidas contra a sociedade ou seus sócios, respondendo estes últimos solidaria e ilimitadamente pelas obrigações sociais

\subsubsection{Joint Ventures, Grupos e Consórcios}

\section{Joint Ventures}

Considerável parte da doutrina alude à expressão joint venture, como significando diversas formas de colaboração industrial em nível internacional.

Atualmente é grande a difusão dos contratos joint venture e das joint venture corporations e seu escopo é o de aprimorar as formas de cooperação industrial.

Ensina STRENGER (1992), que a noção de joint venture é de origem jurisprudencial como o fazia notar Miller, seguido de Blake West, W. Jaizer, e outros que a consideravam uma "judicial legislation by classfication", porém não é menos verdade que as atuais realizações joint ventures foram modeladas na prática internacional. E somente a partir do contrato internacional das joint ventures foi possível ter plena percepção dessa realidade negocial para em seguida encontrar os elementos mais significativos de compreensão. 
Em consonância com orientação norte- americana, encontramos na joint venture uma fórmula contratual que consente a instauração de uma relação de colaboração ocasional sem determinação obrigatória de um esquema societário.

A atual prática comercial evidencia uma preocupação cada vez maior das empresas multinacionais em estabelecer joint venture, em face do crescente desenvolvimento dos conglomerados e a adoção, da parte dos mais dinâmicos, de uma estratégia e desenvolvimento essencialmente pragmática através da qual a propriedade do capital acionário é somente um dos elementos, entre tantos, a considerar na programação do investimento.

O objeto do acordo das joint ventures consiste no aproveitamento dos recursos naturais, na produção, distribuição ou pesquisa conjunta, na utilização das patentes ou Knowhow, ou na participação das concorrências de empreitada, e onde evidente a finalidade de realizar a specific-venture, o particular negócio, que, essencial entre os caracteres originários do contrato de joint venture, perdeu parte da relevância na prática comercial internacional.

Duas são as formas de joint ventures: as corporated joint ventures e as contractual joint ventures.

O primeiro tipo é uma sociedade de capital cujos membros são intimamente ligados por vínculo mais pessoal do que financeiro. Ao contrário de um a normal corporation, a joint venture corporation não tem capital dividido em numerosas mãos, mas antes o tem reagrupado em mãos dos sócios fundadores unidos por estreito vínculo fiduciário.

Originária dos Estados Unidos tal forma de integração nasceu duas ordens de razões: 1.Para tornar possível graças a sua estrutura capitalística, investimentos de cada vez maior dimensão; 2. Para limitar os riscos de empresa com exclusão da responsabilidade ilimitada dos membros, sempre respeitando o modelo de relações próprio da joint venture. O esquema da sociedade de capitais é o instrumento operacional que dá origem ao contrato interno, fonte de regulamentação das relações internas e externas da sociedade. 
A joint venture corporation não é outra coisa senão um a espécie de sociedade com responsabilidade limitada, identificando-se como relação associativa que exclui estrutura societária.

A contractual joint venture é, por outro lado, instrumento elástico e sempre alterável segundo as exigências do momento, evitando o risco de nacionalizações, consagrando o regime de direito e pessoal das relações internas.

A essência da joint venture é a complementaridade dos membros possibilitando mais facilmente constituir empresas economicamente menos sujeitas aos percalços da atividade comercial.

No âmbito da categoria contrato de joint venture é possível compreender e distinguir, partindo da evolução dos entendimentos no contexto das relações comerciais internacionais, os contratos tendo por objeto a execução de várias prestações em função de um investimento (joint venture denominadas operacionais) e aqueles que encontram o momento causal na execução de um contrato a ser estipulado com terceiro (joint venture instrumentais).

A joint venture operacional representa a fórmula do futuro no panorama das atividades comerciais internacionais, com o superamento da natureza ocasional da espécie em sua formulação originária.

Nas joint ventures operacionais o objetivo econômico é realizado e seguido não no exercício em comum de uma atividade, mas na coordenação das ações desenvolvidas pelos contraentes em conformidade com o regulamento negocial, em função das relações do negócio.

BAPTISTA (1996) deduz de análises que empreendeu no campo conceitual alguns pontos comuns às definições mais conhecidas de joint venture: a) a origem e o caráter contratual; b) o direito dos participantes; independentes entre si, à gestão conjunta (mesmo que nem sempre isto ocorra na prática); c) a natureza associativa e o objetivo e/ou duração determinadas; d) o caráter não formal do contrato; e) a facilidade de constituição. 
E acrescenta o subsequente comentário: "Na prática, parece que a forma adotada preferencialmente nos países ocidentais é a da equity joint venture, cuja exteriorização é uma stock corporation nos Estados Unidos, ou nos países de direito tipo "continental" uma sociedade anônima (a "aktiengesellschaft, a "Kabushiki Kaisha”, a "società per azioni”, a “sociedade anônima", entre outras) ou uma forma societária mais fechada, como a sociedade de responsabilidade limitada ( a "GMBH" alemã e austríaca, a "yugen Kaistha”japonesa e seus homólogos em outros países). Esses últimos parecem exercer uma atração por causa de sua flexibilidade legislativa; entre os primeiros é pelo prestígio a possibilidade de atrair capitais locais, dispersados e divididos, que não terão influência na empresa, mas que representam uma fonte importante de financiamento.

\section{Grupos e Consórcios}

O sistema jurídico brasileiro contempla as duas formas básicas de joint ventrues, quais sejam, a corporativa e a contratual, sob a epígrafe de grupos e consórcios, respectivamente.

MARTINS (1998), estabelece a seguinte conceituação:

"Grupo de sociedades é o conjunto e sociedades, constantes de uma controladora e outra ou outras controladas que, por uma convenção entre si, se obrigam a combinar recursos ou esforços para a realização dos seus objetivos, ou a participação em empreendimentos ou atividades comuns. A sociedade controladora comanda o grupo, exercendo, direta ou indiretamente, e de modo permanente, o controle das sociedades filiadas; cada sociedade, entretanto, conservará personalidade e patrimônios próprios".

A sociedade controladora do grupo deve ser brasileira e o grupo terá designação de que constarão a expressão "grupo de sociedades" ou simplesmente grupo. 
Deverá haver uma convenção, que especificará a estrutura administrativa do grupo e a coordenação ou subordinação dos administradores da sociedades filiadas. Os grupos de sociedade são largamente utilizados por grandes empresas em todo o mundo, e a literatura jurídica sobre os mesmos é abundante.

Uma companhia que, por seu objeto, necessite de autorização do governo para funcionar, somente poderá participar de um grupo se a convenção do mesmo receber aprovação da autoridade competente para aprovar alterações do seu estatuto.

O grupo é considerado constituído a partir da data em que forem arquivados no Registro do Comércio da sede da sociedade de comando a convenção, as atas das assembléias gerais ou os instrumentos de alteração contratual das sociedades que aprovaram a constituição do grupo; a declaração autêntica do número de ações ou quotas de que a sociedade de comando e as demais sociedades são titulares em cada sociedade filiada ou exemplar de acordo de acionistas que assegure o controle da sociedade filiada. Estando as sociedades sediadas em locais diferentes, no Registro do Comércio da sede de cada sociedade filiada, serão arquivadas as atas das assembléias gerais ou alterações contratuais que tiverem aprovado a convenção. Cada sociedade participante do grupo, a partir do arquivamento da convenção de constituição, passará a usar o seu nome social acrescido da designação do grupo.

A administração do grupo deverá ser estruturada na convenção de constituição; pode estabelecer que o grupo terá órgãos de deliberação colegiada e cargos de direção geral. No entanto, a representação de cada sociedade perante terceiros, salvo disposição expressa na convenção, devidamente arquivada no Registro do Comércio e publicada, cabe exclusivamente aos administradores das mesmas, na forma dos seus estatutos ou contratos.

Além das demonstrações financeiras comuns de cada uma das companhias agrupadas, deve o grupo publicar demonstrações consolidadas, juntamente com as da sociedade de comando. 
Consórcio, por sua vezé o contrato feito pela companhia e outras sociedades com a finalidade de executar determinado empreendimento. Deve esse contrato ser aprovado pelo órgão da sociedade que tiver competência para autorizar a alienação de bens do ativo permanente, e dele constarão a designação do consórcio, se houver, o empreendimento que constituir seu objeto, a duração, endereço e foro, as obrigações e responsabilidades e as prestações específicas de cada sociedade consorciada. Figurarão ainda as normas relativas à administração, contabilização, representação das sociedades consorciadas e taxas de administração, se houver. Deve, ainda, o contrato estipular a forma de deliberação sobre assuntos de interesse comum, com o número de votos que cabe a cada sociedade consorciada e a contribuição, se houver, de cada consorciada para as despesas comuns. Esse contrato, bem como suas alterações, deve ser arquivado no Registro do Comércio do lugar da sede de consórcio, sendo publicada a certidão do arquivamento.

O consórcio não tem personalidade jurídica; as consorciadas respondem apenas pelas obrigações assumidas, sem presunção de solidariedade. A falência de uma consorciada não se estende às demais, permanecendo o consórcio com as outras contratantes; os créditos que a falida tiver no consórcio serão apurados e pagos na forma do contrato. 


\section{Aspectos Jurídicos das Organizações e Empresas Virtuais de interesse para a Teoria Geral da Administração}

\subsection{Uma abordagem necessariamente sistêmica}

De tudo quanto já foi descrito acerca das Organizações Virtuais e Empresas Virtuais, um dos aspectos mais relevantes e que constitui verdadeiro "divisor de águas" está em que aquelas passam a ter os atributos de uma empresa tradicional, sem que o sejam do ponto de vista formal-legal. Ou seja, não se materializam através de nenhuma das formas existentes de sociedade comercial, até porque nenhum dos modelos de contrato ou contrato social, isoladamente, dão conta dos processos de formação, propósitos ou duração dessa modalidade de cooperação.

Se de um lado observa-se que as empresas preservam sua independência e autonomia, por outro lado, quando estão ligadas pelo propósito da cooperação, seja na fase de OV ou numa situação mais avançada como uma EV, afiguram-se como subsistemas de um sistema maior, enfrentando os mesmos percalços e demandando a mesma atenção que merece uma organização. Nesse sentido, propor uma infra-estrutura jurídica importa em reconhecer a adoção de uma visão sistêmica da organização e evidenciar o seu papel sobre pelo menos algumas de suas características mais críticas, que segundo NADLER \& TUSHMAN(1994) seriam: interdependência interna, capacidade de feedback, equilíbrio, equifinalidade e adaptação. Todas estas entrarão em linha de consideração justamente por condicionarem e estarem condicionadas à infra-estrutura legal explicita. 
Assim, a eficiência do sistema, por mais que se almeje um informalismo total, depende de algumas amarras. Se dentro de uma organização tradicional as mudanças ou inoperância de uma unidade de produção são reconduzidas ao seu eixo por obra da alta administração por simples imposição de comando, legitimado em última análise pela propriedade patronal, tal não ocorreria em se tratando e uma unidade de produção situada dentro dos limites legais de um dos parceiros numa organização virtual. Não é forçoso concluir que com relação ao equilíbrio e à adaptação tudo dependerá de uma tomada de posição conjunta e unânime dos parceiros.

TRÖNDLE ${ }^{3}$ apud PICOT et al. (1997) descreve a essência da cooperação tendo como critérios os níveis de autonomia e de interdependência. Empresas que realizam cooperações não deixam de ser autônomas no sentido de decidir entrar ou abandonar a cooperação, logo não consultam um nível mais alto para a tomada de decisão. Desta forma, entende-se que todos os parceiros da cooperação estão num mesmo nível. Este aspecto diferencia a cooperação de estruturas governantes, que se caracterizam pela não voluntariedade do cooperare e pelo fato de poderem surgir de contratos que dão margem a acordos implícitos.

A interdependência surge após a formação da cooperação, pois se relaciona com a tomada de decisão coletiva. As cooperações entre empresa surgem como um meio de "alavancar" recursos, onde os processos de acordo e negociação devem arcar com a decisão da quantidade e qualidade dos recursos a serem aplicados na cooperação. Igualmente, tais processos devem garantir a igualdade de negociação entre todos os parceiros, a fim de não se afugentar aqueles mais fracos.

Embora essas características sejam observáveis nas OV e EV, confirmando o comportamento sistêmico, vale destacar que os elementos interrelacionados numa organização tradicional estão todos subordinados à figura dos proprietários controladores.

\footnotetext{
${ }^{3}$ TRÖNDLE, D. (1987) Kooperationsmanagement. Steuerung interaktioneller Prozessen bei Unternehmenskooperationen. Eul, Bergisch - Gladbach apud PICOT, A. et al. (1997) Information, Organization and Management - Expanding Markets and Corporate Boundaries. London, John Wiley \& Sons
} 
Numa organização virtual os elementos componentes do sistema são as próprias unidades de negócio coordenadas por representantes legais, os quais tem legitimidade para se vincularem externamente.

A cooperação entre empresas é ainda marcada pelo caráter voluntário e pela existência de acordos contratuais explícitos. O caráter voluntário significa que todos os parceiros envolvidos esperam benefícios da cooperação (PICOT et al. (1997)).

A natureza autônoma dos elementos componentes irá afetar sobremaneira a estrutura do sistema a que pertencem. Às regras e princípios da Teoria da Administração aplicáveis à uma organização tradicional, devem ser acrescidas necessariamente às regras provenientes da regulamentação estatal, uma vez se torna mais relevante para o Estado o que se passa no ambiente inter-organizacional do que aquilo há muito tempo está sedimentado nas relações internas de uma organização, assim considerada como unidade jurídica.

Implicações referentes ao Direito do Trabalho bem como ao Direito Tributário, são evidentes, entretanto, dada a amplitude da análise que demandam e sua pouca afetação ao modelo ora proposto, que é flexível o suficiente para acomodar situações várias, não serão tratadas de maneira central complementar e superficial.

\subsection{Insuficiência das normas éticas para suportar os processo de formação das E.V.}

O comportamento ético dentro de uma organização tradicional se sustenta basicamente por dois fatores. Primeiro a expectativa de demissão do trabalhador, caso sua conduta fira a cultura já sedimentada dentro da empresa. Segundo, a consciência do trabalhador de que sua conduta é observada pelo mercado de trabalho como um todo. Assim, independente de qualquer regra escrita ou inserida no contrato de trabalho, os valores da organização bem como seus padrões de comportamento são razoavelmente preservados e perpetuados. 
Nesse prisma, a história como fator contextual do insumo, é sensivelmente impactada pela ética, o que não ocorre nas organizações virtuais, que se criam mais em torno de impulsos ambientais do que de uma relação antiga e duradoura. Com efeito, "...é particularmente importante compreender as fases principais do desenvolvimento da organização no decorrer do tempo, bem como o atual impacto dos acontecimentos passados por exemplo, decisões estratégicas anteriores, o comportamento dos líderes, a natureza das crises passadas e as reações da organização, bem como a evolução dos valores e normas básicos". (NADLER et al., 1994, p 36).

Embora não exista nenhum modelo que comporte o desenvolvimento de uma OV ou $\mathrm{EV}$, conforme descrito no tópico anterior, por outro lado não é possível dispensar um mínimo de estruturação em torno de regras jurídicas.

Talvez por conta de um apego exagerado a outros componentes organizacionais, com desprezo da organização formal, muitas vezes descrita como elemento estático, descrevemse as OV e EV como sistemas que repousam basicamente na informalidade e confiança. THOMPSON \& McEWEN ${ }^{4}$ apud CHIAVENATTO(1993), descrevem três subtipos de estratégia cooperativa: ajuste, coopção e coalizão. Para aqueles autores, a "coalizão refere-se a uma combinação de duas ou mais organizações para um objetivo comum. Trata-se de uma forma extrema de condicionamento ambiental dos objetivos de uma organização. Duas ou mais organizações agem como uma só, com relação a determinados objetivos, principalmente quando há necessidade de mais apoio ou recursos que não são possíveis para cada organização isoladamente. A coalizão exige o compromisso de decisão conjunta de atividades futuras e, assim, limita decisões arbitrárias ou unilaterais; é uma forma de controle social". Finalizam afirmando que "todas essas estratégias cooperativas requerem a interação direta entre organizações, o que aumenta o controle potencial do ambiente sobre a organização.

\footnotetext{
${ }^{4}$ THOMPSON J. D. e MACEWEN W. J. (1975). "Objetivos de Organização e Ambiente: Estabelecimento de Objetivo como um processo de Interação", in Dorwin Cartwright e Alvin Zander, Dinâmica de Grupo. Pesquisa e Teoria, São Paulo, editora Pedagógica e Universitária/ Editora da Universidade de São Paulo, , pp. 590-597.
} 
Essa percepção contingencialista, presente nas premissas que justificam o surgimento do fenômeno virtual, demonstra o papel preponderante do ambiente sobre o formato da organização e principalmente a vulnerabilidade desse tipo de organização ante a possibilidade de ruptura das estruturas informais que se desenvolvem em seu seio.

$\mathrm{O}$ conjunto de atributos que caracterizam as OVs e EVs, e que resumidamente poderiam ser citados como, oportunismo, excelência, confiança, agilidade, informalismo, uso de tecnologia de informação, competência essencial etc., traz implícita a crença de que parceiros que preenchem tais requisitos, por si sós estariam aptos a cooperar em um ambiente absolutamente livre de estruturas legais rígidas, amparados apenas por compromissos morais, uma vez que nem mesmo os modelos existentes são suficientes para suportar esse novo paradigma empresarial.

Como já demonstrado no item 2.2.3 retro, as normas de natureza ética, entretanto, também são insuficientes para reparar, ou restabelecer o status quo ante, quando as atribuições e as obrigações afetas a determinado parceiro deixam de ser observadas. O constrangimento, o remorso do infrator ou até mesmo a repulsa de todo o grupo, não têm o condão de ressarcir prejuízos e são irrelevantes ao direito. De tal sorte que não há como garantir que uma EV se desenvolva sem sua plenitude e se dissolva apenas e tão somente repousando na crença de que cada qual cumprirá sua particular missão. Nada obsta que tal possa acontecer, e talvez fosse essa a expectativa geral, porém o envolvimento de capitais e os ativos imateriais tais como nome comercial e reputação, especialmente em economias em desenvolvimento, com instabilidade econômica, faz com que os próprios protagonistas do fenômeno virtual se sintam desamparados por falta de regras claras e portanto escritas, o que ipso facto transfere a regra do campo moral para o campo jurídico. 


\subsection{A perspectiva do empreendedor e sua forma de vinculação}

Partindo-se da ótica do empreendedor que se veja premido pelo ambiente e adote como estratégia cooperar com outros empreendedores em torno desse novo paradigma, é natural que de imediato procure esquemas legais em torno dos quais se garantir. Tais esquemas levam em conta as razões pela quais foi motivado a cooperar.

Existem duas motivações básicas que levam as empresas a buscarem cooperações. A primeira é a consolidação da posição de mercado (como atendimento de pedidos e assistência técnica), a segunda, a aquisição de novas vantagens competitivas (redução de tempo de desenvolvimento de produto). Segundo FRESE (1993), tais motivações subdividem a estratégia de uma empresa:

- A estratégia de negócios, que compreende decisões de longo prazo, como quais mercados ou segmentos serão almejados e quais as ferramentas e tecnologias serão necessários para se atingir os objetivos;

- A estratégia competitiva, que deverá descrever como a empresa se comporta no ambiente competitivo, obtendo vantagens frente aos concorrentes.

A adoção da cooperação através de OV e EV, à luz dessa subdivisão proposta por FRESE(1993), darão a tônica aos seus respectivos contratos em torno de estratégias de negócio e competitiva, respectivamente.

Assim, sua primeira reação, ainda que intuitiva é valer-se do princípio da livre iniciativa e gerar suas próprias regras de comportamento. 
Se por um lado não existem modelos adequados, ou estes isoladamente não suportam todas as etapas de uma EV ou simplesmente negam sua própria natureza, é certo por outro lado, pelo que se demonstrou até aqui, que um ou vários contratos afiguram-se indispensáveis. É em torno da idéia de contrato, e das múltiplas formas que este pode assumir e se coligar a outros contratos, que se deve buscar as respostas adequadas para o enfrentamento das exigências da virtualidade, sem arredar ou desfigurar aqueles aspectos tão úteis e desejáveis.

O sistema jurídico brasileiro, que se insere na família do direito romano-germânico, tem na lei a sua principal fonte de regulamentação da sociedade, e relega ao plano dos contratos a disciplina jurídica entre os particulares, como fonte de obrigações imediata, desde que não contrariem disposições legais. Sendo assim, do ponto de vista do conteúdo dos contratos, é de se concluir que, realmente, aos particulares é dado fazer aquilo que a lei não proíbe, especialmente criar obrigações, que não sendo contrárias à lei, dela recebem sua força cogente.

De outra parte, com relação à forma dos contratos, observa-se também grande liberdade, desde que a lei não determine expressamente a forma solene para a validade do contrato. É o que, com mais clareza, diz o art. 129 do Código Civil, ao estabelecer que: “A validade das declarações da vontade não dependerá de forma especial, senão quando a lei expressamente a exigir."

Algumas vezes, para a sua validade, estabelece a lei que os contratos devem revestirse de formas especiais. O Código Civil, referindo-se aos atos jurídicos em geral, estatuiu (art.130) que "não vale o ato que deixar de revestir a forma especial determinada em lei", regra essa assentada no art. 82, que, de modo amplo, estabelece que "a validade do ato jurídico requer agente capaz, objeto lícito e forma prescrita ou não defesa em lei”. Caso o ato, para que a lei determinou forma especial, não se revista dessa forma, será considerado nulo, nos termos do art. 145, $\mathrm{n}^{\circ}$ III, do Código Civil. 
Como na lógica cartesiana do sistema romano-germânico, há uma tendência natural à codificação e a edição de leis, aquilo que em inglês já se denominou statute law, visando a disciplina e a regulamentação de quase todos os aspectos do convívio social, prevendo em pormenores para todas as situações, disso resulta que um número pequeno de situações já não tenham merecido a preocupação do legislador.

Nesse sistema, as mudanças sociais são observadas pelo legislador, que em atividade subsequente, procurará regulamentar situações futuras fixando comandos genéricos e abstratos. Entretanto, as mudanças na economia, por serem mais velozes que as mudanças noutras esferas, como a das relações de família, por exemplo, geram um certa perplexidade tanto para doutrinadores quanto para legisladores, muitas vezes resultando num vazio regulamentar. A INTERNET é a melhor prova dessa assertiva. Se durante muito tempo a localização da sede e o centro gravitacional dos negócios eram havidos como importantes elementos determinadores da legislação aplicável para superação do conflito de leis no espaço, o denominado "e commerce" ou o "e business" deslocam o centro gravitacional para um ambiente virtual sem fronteiras geográficas, demandando novos critérios legais.

No campo próprio das EVs e OVs, especialmente no Brasil, o fenômeno ainda não foi absorvido ou sequer percebido pelo legislador, muito embora se possa dizer que o consórcio, conforme adrede conceituado, constitua uma modalidade de contrato que permite a realização de empreendimento comum entre empresas, sem que estas percam sua independência e autonomia, não resultando, inclusive, em personificação. E curioso notar, conforme preleciona REQUIÃO(1977), que "o consorciamento de sociedades, tendo em vista sua destinação à execução de obras, em nosso país, precedeu à legislação. Institui-se através de uma integração horizontal, na qual dada empresa mantinha sua personalidade jurídica, sem subordinação. O direito brasileiro se apercebeu de sua existência após ter ele se disseminado nos usos empresariais, impondo-se, pouco a pouco, ao legislador"(REQUIÃO, 1977, P. 243) 
Quando surgiram os consórcios, que foram posteriormente regulamentados, pelo Decreto 57.651/66, bem como acolhidos pelo art. 278 da Lei 6.404/76(Lei das S/A), o propósito eram as empreitadas de grande vulto, como obras públicas, mineração, disso resultando a exigência de contrato escrito estabelecendo a designação, o objeto do empreendimento, a duração, o endereço e o foro, normas sobre receita, contabilização e administração etc., conforme estatuído no art. 279 daquele diploma legal, bem como a exigência de ser o contrato registrado no Registro do Comércio. Observe-se portanto, que mesmo na hipótese dos consórcios, que seriam a forma mais livre de cooperação entre empresas, a liberdade encontra-se entabulada, e seus limites também não comportam adequadamente o novo paradigma virtual.

Se por força das circunstâncias o próprio mercado se incumbiu de criar um mecanismo lícito, não obstante a falta de regulamentação, mutatis mutandi, a situação vivida nos dias atuais em torno do novo paradigma, permite expender o mesmo raciocínio. Ou seja, impende desenhar, dentro da licitude e da liberdade das formas, contratos que suportem as novas formas de cooperação entre empresas.

No direito moderno, é facultado criar, mediante vinculo contratual, quaisquer obrigações. O conteúdo dos contratos pode ser estruturado livremente. As pessoas que querem obrigar-se não estão adstritas a usar as espécies contratuais definidas na lei. Ocorre entretanto, que por conta da frequiência com que as relações econômicas se travam sob determinada forma jurídica, esta formas acabam se tornando típicas. Disso resulta que as espécies mais comuns são objeto de regulamentação legal, individualizando-se por denominação privativa, com traços característicos inconfundíveis. A cada forma de estrutura econômica da sociedade correspondem espécies de contratos que satisfazem as necessidades mais instantes, havendo portanto uma preponderância de determinados tipos de contrato em cada fase da evolução econômica. Justamente esses contratos mais freqüentes acabam merecendo maior atenção de doutrinadores e legisladores, e acabam sendo esquematizados em lei, por isso são chamados de contratos nominados ou contratos típicos. 
Os contratos que se formam à margem dos paradigmas estabelecidos - como fruto da liberdade de obrigar-se - denominam-se contratos inominados ou atípicos, segundo ensina GOMES(1979).

Um contrato atípico pode ser resultante dos seguintes movimentos:

a) pela modificação de elemento característico de contrato típico, sob forma que o desfigura dando lugar a um tipo novo;

b) pela eliminação de elementos secundários de um contrato típico;

c) por interesses novos, oriundos da crescente complexidade da vida econômica, cuja disciplina é estipulada livremente sem padrão de observação.

O interesse do empreendedor, qual seja o de organizar-se em torno de uma Organização Virtual ou realizar negócios através de uma Empresa Virtual, não está especificamente disciplinados na lei, nada obstando porém que o faça através dos mecanismos acima descritos, tendo como consequiência apenas o fato de que ele se será sempre um contrato atípico, até que a lei o nomine ou tipifique.

\subsection{O papel e a feição do contrato diante da nova estrutura de comunicação}

A flexibilidade é o objetivo principal na formação de uma OV, e ela se descreve como sendo a capacidade da organização se adaptar às mudanças de ambiente. Segundo WIGAND(1997), quanto mais turbulentas as condições do ambiente e maiores as variações da demanda, melhor sucedida será a estratégia de flexibilidade. 
Para o mesmo autor algumas empresas tendem a acreditar que uma OV representa uma estrutura organizacional estratégica. Isto é questionável uma vez que ela não funciona para todo tipo de negócio e suas vantagens dependem dos propósitos e suas especificações.

Se a tecnologia de informação e de comunicação podem representar um importante alento em favor da flexibilidade da organização, pode também representar um obstáculo diante de uma inflexibilidade técnica, relacionada com a competência essencial que está sendo procurada. Além desses fatores, a própria flexibilidade interna dos parceiros é relevante para que a OV atinja seu objetivo de ser flexível. Portanto, uma premissa básica para que OV e EV representem efetivamente uma alternativa estratégica, consiste no fato de que internamente o pretenso membro ou parceiro tenha um organograma mais horizontal, focado nos times.

Aquilo que era dado à gerência de nível médio ou inferior, passa a ser necessariamente objeto de preocupação da alta administração, ou seja, as variáveis operacionais conforme preleciona LODI(1988), relacionadas à estrutura da empresa, os níveis de desempenho, avaliação e controle, passam a ser componentes da análise estratégica.

Isso se deve ao fato de que é próprio das $\mathrm{OV}$ serem formadas por specilized teams, e a comunicação nesse ambiente atravessa as fronteiras da estrutura hierárquica. Portanto os parceiros já devem estar afeiçoados a este tipo de organização interna.

Como são esses times que vão lidar com o fluxo de informações, serão emissores e receptores de mensagens, uma condição básica para que os contratos funcionem é justamente contemplar esta particularidade. O papel do proprietário ou da alta administração será apenas o de legitimar os contratos. Estes deverão assumir uma feição meramente técnica, sem cláusulas ou linguagem jurídica. Isto porque, "uma organização dinâmica caracteriza-se por indivíduos dotados de poder de decisão em equipes que lançam mão do que for necessário e realizam o que julgam ser mais adequado, dentro de parâmetros amplos definidos por executivos orientados à missão"(GOLDMAN et al., 1995,p.325). 
Mais importante, portanto, do que firmar e se responsabilizar pelos efeitos de um contrato, nesse caso, é garantir a sua execução. A execução de um contrato de EV é toda confiada aos times, e o desempenho dos times consiste simplesmente em colocar em andamento o plano de negócios. As informações necessárias numa EV são as informações sobre os projetos, o que inclui aspectos relacionados à administração, as tarefas e a motivação de um projeto específico. Como os membros de uma equipe são oriundos de empresas diferentes, com elas mantendo seu respectivo contrato de trabalho, obviamente, no vazio de uma confiança plena, haverá obstáculos ao fluxo pleno de informações. De um lado, esses operadores podem ainda não ter superado a idéia de competição entre as empresas às quais estão ligados, por outro quanto maior o fosso entre a alta administração e os integrantes das equipes, menor a agilidade e liberdade para tomadas de decisão rápidas.

Dentro de uma EV, em função do poder que representa a concentração de informações, e dada a necessidade de as empresas se ligarem por suas essências de maneira enxuta e objetiva, há uma mitigação do papel da alta administração no esquema tradicional, onde os níveis mais baixos dependiam do topo, o topo tomava uma decisão e os níveis mais baixos a executavam. O sentido agora é outro, o titular de uma empresa toma a decisão de se engendrar parcerias sob a forma de EV, e a partir daí disponibiliza sua essência para cooperar e vê-se na contingência de tomar conhecimento quase que a posteriori, de uma série de pequenas decisões de caráter operacional, tomadas pelas pessoas responsáveis pela conexão de ativos e informações dentro das equipes então formadas. Isso se deve ao fato de que são justamente estas pessoas que mantém contato com as partes em arranjo, com os clientes e fornecedores, dispondo portanto de informações suficientes para a tomada de decisão. 
Como não existe uma estrutura formal, preconcebida para comunicação dentro de uma EV, sob pena de retirar velocidade e flexibilidade no aproveitamento das oportunidades e suas múltiplas exigências de arranjo, as atitudes em relação à cooperação e as habilidades para comunicação são mais importantes que convenções formais e procedimentos oficiais de comunicação. Isso é tarefa que o titular da empresa ou a alta administração deve assumir logo no momento em que resolve se ligar com parceiros externos.

Nesse sentido, havendo confiança interna com relação aos membros da equipe, o que é uma condição básica, o contrato deve ser concebido para ser executado em sua plenitude ao próprio operador das informações, através de delegação, chegando às suas mãos sob forma de uma missão, com liberdade de ação, uma vez que nesse ambiente a troca de dados é muito mais frequente do que numa organização tradicional e o informalismo é também é a tônica.

Se de um lado a parceria se desenvolve entre entidades legalmente independentes, o que constitui inclusive uma premissa central deste trabalho, por outro lado, as demais fronteiras organizacionais tornam-se bastante imprecisas, especialmente as fronteiras da comunicação. Em função do uso compartilhado de conhecimentos e experiências pelas empresas parceiras, a comunicação tem que cobrir toda a rede. Isso torna difícil distinguir entre comunicação interna e comunicação externa. Quando as fronteiras tradicionais desaparecem, a comunicação se desenvolve a tal ponto que o conhecimento acumulado de cada empresa tende a entrar em sintonia, aumentando também os fluxos de informação para dentro e para fora de cada unidade legalmente autônoma.

De tudo quanto foi resgatado na literatura acerca das principais características das empresas virtuais - as quais não se confundem com organizações virtuais, cujo traço diferenciador reside no fato de serem redes estáveis, podemos sintetizar, elencando os seguintes aspectos: 
I. cooperação entre instituições legalmente independentes;

II. competências essenciais compartilhadas dentro de uma mesma cadeia de valor;

III. estrutura organizacional rígida;

IV. temporário;

V. recurso- conhecimento, risco - compartilhado

Esses são os elementos que serão obejto de consideração na concepção da infraestrutura jurídica. Observe-se porém que a independência legal, nesse passo, só pode significar que os parceiros entram em cooperação agregando apenas aquilo que têm de melhor para a concretização do serviço ou produto final, sem alterarem os traços que os individualizam, ou seja, sem comprometerem os contornos de sua própria personalidade jurídica. Atingida a meta, mais precisamente atendida a demanda, não há razão para perpetuação da empresa.

Os modelos atuais, exceção feita às joint ventures, que nos mais das vezes se justificam apenas para grandes projetos multi-nacionais distantes do paradigma virtual, não contemplam a idéia de uma oportunidade específica de negócio, contemplam empresas que estejam programadas para atender em caráter permanente determinado mercado, e que ele vão se ajustando, de acordo com a demanda, aumentando e diminuindo a produção e alterando seu mix de produtos. 
Nas EVs, a comunicação torna-se um fator crítico, desempenhando papel central na capacidade de feedback conforme já descrito anteriormente dentro daquela perspectiva sistêmica esposada por NADLER \& TUSHMAN(1994). O contrato de EV, deve contemplar essa perspectiva, a perspectiva do operador da informação e da comunicação, que será o executor do contrato. Para ele, uma linguagem direta e objetiva basicamente ligada ao projeto, a fim de não impor obstáculos à perfeita troca de informações internas e com o meio externo.

A fim de compatibilizar os atributos inerentes às EVs e OVs com o sistema jurídico brasileiro, sem qualquer prejuízo às suas respectivas definições, serão abordados no Cap. 4, temas restritos e específicos de direito, que serão manipulados como informação científica no sentido de se construir uma solução para o dilema segurança/agilidade. 


\section{Proposta de uma infra-estrutura Jurídica aplicável a empresas virtuais no Brasil}

Propor um infra-estrutura jurídica, implica antes de mais nada em acreditar na possibilidade de gerar maior eficiência através de uma postura racionalista, e afetar todos os elementos componentes de uma organização, pela manipulação de sua estrutura formal explícita. Refoge ao cerne deste trabalho analisar os padrões de comportamento dos trabalhadores face ao novo paradigma, entretanto, o modelo discutido, tanto quanto possível se propõe a ser flexível o suficiente para contemplar também o indivíduo, como um potencial parceiro nas organizações virtuais. Tal crença decorre da observação de que a cooperação entre empreendedores é uma tendência, e cada vez mais suas ligações ocorrem dentro de suas melhores aptidões. Embora as relações entre empreendedores tendam naturalmente para um maior informalismo, determinado por aspectos históricos, no que diz respeito às unidades de negócio de que são titulares - consideradas em sua totalidade, as estruturas informais não surgem espontaneamente da noite para o dia e são necessários meses e até anos e muitas atividades conjuntas para que tal ocorra.

A fim de superar essas fronteiras, entre unidades juridicamente autônomas dotadas de suas respectivas estruturas formais e informais, o que se pretende é oferecer mecanismos estratégicos, de opção dos titulares dessas unidades que permitam uma ligação mais estreita e segura, lançando bases inclusive para o desenvolvimento da confiança e do informalismo. 
A definição de uma infra-estrutura que contemple tanto as características dessa peculiar parceria quanto a motivação que leva o empreendedor a engendrá-la, de acordo com as peculiaridades do nosso Direito, passa necessariamente por um tratamento diferenciado a ser dispensado tanto para as OV, quanto para as EV. Sustenta-se com isso, que há uma melhor adequação aos modelo teóricos, se ambas as entidades forem tratadas como etapas de um processo. Ou seja, a OV como uma fase que antecede ao surgimento das EV.

Dado que a "EV é uma rede temporária de empresas independentes - fornecedores e clientes, até mesmo rivais - interligadas por tecnologia de informação, para compartilhar habilidades, custos e permitir o acesso comum aos mercados dos mesmos" e por "não possuir escritório central nem organograma, hierarquia ou integração vertical" (BYRNE, 1993), fica claro, à luz das regras consagradas pelo nosso sistema jurídico, que adoção pura e simples de um modelo, como sociedade anônima, por cotas, em comandita, capital e industria etc., implicaria na negação daquelas características apontadas. Com efeito, o empreendimento forçosamente teria que ser perene, sem prazo para acabar, com toda sorte de embaraços burocráticos e registrários tanto no momento da criação quanto no da dissolução; as empresas deixariam de ser independentes; haveria a necessidade de criação de um organograma definindo encargos administrativos e contábeis; não haveria como contemplar no mesmo organograma clientes e empresas rivais.

A contribuição de cada parceiro não ficaria mais restrita às suas competências essenciais mas seria uma contribuição total, com todo o peso de cada entidade, com seus ativos e trabalhadores. Seria a própria negação da agilidade reclamada nos tempos atuais.

Um primeiro passo, então, seria definir a infra-estrutura de uma OV, bem como dotála dos elos necessários para seus desdobramentos subsequentes, especialmente a ocorrência das EV, nesse sentido é necessário excluir aquilo que não é adequado. 


\subsection{Exclusão dos modelos existentes}

\section{Sociedades Comerciais}

Embora já se tenha admitido linhas atrás que a OV é uma rede estável de empresas, impende descartar desde logo toda e qualquer hipótese de sociedade comercial para emoldurá-la. Em primeiro lugar, a OV não está destinada a realizar trocas com o meio externo, não é seu objetivo adquirir bens e revendê-los e muito menos processá-los industrialmente, sua missão básica é ambientar trocas de informações para conhecimento mútuo de potencialidades entre várias empresas ou empreendedores individualmente considerados.

Em segundo lugar, as sociedades comerciais implicariam numa nova estruturação burocrática com centralização do poder em função do aporte de capital oferecido por cada um dos membros, significando de um lado alienação de parte de sua autonomia e de outro desaparecimento ou esvaziamento do próprio parceiro

Por fim, não é demais ressaltar que uma nova empresa é a própria negação da idéia de Organização Virtual pelo formalismo e visibilidade exigidos pela legislação. Com efeito, como atos que requerem forma especial estão as sociedades comerciais, exigindo o Código Comercial(art.300) que a constituição delas seja sempre feita por escritura pública ou instrumento particular; e o art. 302 estabelecendo as cláusulas obrigatórias como denominação, sede, objeto específico, cotas entre outras. 


\section{Joint Venture}

Conforme definição anteriormente dada, a Joint Venture é fruto de construção jurisprudencial não aplicável ao Brasil. Não que tal modalidade não seja lícita, apenas o seu reconhecimento legal se dá por outras bases: se for do tipo corporativa recebe a denominação de "Grupo de Sociedades", se for do tipo contratual recebe o nome se "Consórcio".

De plano é possível descartar essa primeira hipótese, de Grupo de Sociedades, uma vez que necessariamente deverá haver uma sociedade controladora, que segundo MARTINS(1998), comanda o grupo, exercendo, direta ou indiretamente, e de modo permanente, o controle das sociedades filiadas, havendo inclusive a necessidade de registro na Junta Comercial, implicando na criação de uma sociedade de sociedades, muito embora cada qual conserve personalidade e patrimônios próprios. Além do mais, a sociedade controladora do grupo deve ser brasileira e o grupo terá designação de que constarão a expressão "grupo de sociedades" ou simplesmente grupo.

Deverá haver uma convenção, que especificará a estrutura administrativa do grupo e a coordenação ou subordinação dos administradores da sociedades filiadas, segundo o art. 245 da Lei das S/A. Ou seja, esse quadro fere completamente a idéia de ausência de hierarquia, organogramas flexíveis, trabalho em equipe, integração horizontal, etc. 
Por outro lado, o Consórcio, também não condiz com as premissas da virtualidade. Não condiz com as OVs pelo fato de não ter como objetivo básico o fornecimento de serviços ou produtos ao meio externo. Com as EVs não condiz pelos embaraços registrários que apresenta. Embora destine-se o contrato a executar empreendimento específico, este deve ser aprovado pelo órgão da sociedade que tiver competência para autorizar a alienação de bens do ativo permanente, e dele constarão a designação do consórcio, se houver, o empreendimento que constituir seu objeto, a duração, endereço e foro, as obrigações e responsabilidades e as prestações específicas de cada sociedade consorciada. Figurarão ainda as normas relativas à administração, contabilização, representação das sociedades consorciadas e taxas de administração, se houver. Esse contrato, bem como suas alterações, deve ser arquivado no Registro do Comércio do lugar da sede de consórcio, sendo publicada a certidão do arquivamento.

Cumpre ressaltar entretanto, que conforme o caso, esta talvez signifique uma alternativa eficaz. É o caso por exemplo de uma EV que se torne duradoura e sua produção se torne seriada ou massificada, o que paradoxalmente vai determinar o fim da virtualidade. Não é demais relembrar que o consórcio não tem personalidade jurídica; as consorciadas respondem apenas

pelas obrigações assumidas, sem presunção de solidariedade. Essa modalidade eqüivale aos, consortium definido por BERWANGER (1999), que apresenta como desvantagens o fato de que nenhuma das empresas garante ao cliente ou consumidor o desempenho total e integrado das missões assumidas por cada uma delas, sendo constituídas basicamente para atender grandes projetos industriais.

Cooperações do tipo Joint Venture se formam em situações que envolvem atividades de natureza tecnológica muito complexas, as quais uma empresa sozinha não pode - ou não consegue - gerenciar. Segmentos como a indústria aerospacial ou de microeletrônica são exemplos onde são comuns Joint Ventures. 


\section{Cooperativas}

As cooperativas embora tragam no nome uma promessa de solução para o nosso problema, em termos de estruturação, finalidade e pressupostos, encontram-se muito longe do modelo almejado.

Cabe lembrar logo de início que há necessidade de autorização estatal, muito embora apresentem características comuns às associações civis. São legalmente consideradas sociedades não empresariais (Lei n. 5764/71, arts. $3^{\circ}$ e $4^{\circ}$ ), que prestam serviços aos associados sem objetivo de lucro; não há um processo acumulativo de investimentos e reinvestimentos societários, segundo DINIZ(1996). A sociedade cooperativa poderá constituir-se por deliberação da assembléia geral dos fundadores, por instrumento particular, por escrita pública, pressupondo um número mínimo de vinte associados. . O ato constitutivo é um contrato de sociedade, que se aperfeiçoará com a autorização de funcionamento pelo órgão público competente(art. 17). Uma das funções centrais da cooperativa é a troca direta de bens e serviços com seus cooperados, eliminando intermediários na circulação da riqueza. Podem ser elencados os seguintes papéis assumidos pelas cooperativas: produção agrícola; produção industrial; de trabalho; de beneficiamento de produtos; de compras em comum; de venda em comum; de consumo; de crédito; de seguros; de construção de casas populares; de editoras; e escolares.

Como se vê, seja pelos requisitos registrários, seja pelo número mínimo de integrantes, seja por sua finalidade, qual seja o fornecimento de bens e serviços aos cooperados, através de aquisição em melhores condições no mercado, seja ainda pela existência de um organograma centralizador, o parceiro aqui é mero consumidor associado. 


\section{Fundações}

As fundações conquanto representem papel importante, especialmente hoje em dia, na difusão, fomento e apoio à produção científica e cultural, seu modelo constitutivo é absolutamente incompatível com a idéia de Organização Virtual e muito menos com Empresa Virtual. Apenas como breve consideração, define-se fundação como patrimônio destinado a determinada finalidade. A lei, cumpridos certos requisitos, atribui personalidade a esse acervo de bens, ou seja, atribui-lhe a capacidade para ser titular de direitos. Ou seja, alguém doa o deixa por testamento determinados bens livres especificando a sua finalidade. Seu ato constitutivo é o próprio testamento ou uma escritura pública, onde a vontade de apenas uma pessoa, atendidas as exigências legais, pode gerar uma pessoa jurídica. Isso nada tem a ver com sociedade, parceria ou virtualismo, muito embora possa ser um importante coadjuvante dentro de uma rede de parcerias.

\section{Sociedades Civis}

O mesmo raciocínio expendido para afastar as sociedades comerciais como alternativa, pode ser invocado para as sociedades civis, merecendo apenas observar que estas se distinguem daquelas, basicamente em função da dicotomia artificial existente no nosso Direito, que arbitrariamente define atos como sendo ora de natureza comercial, ora de natureza civil. Tal dicotomia é vestígio da Idade Média, quando os comerciantes dispunham de leis e tribunais próprios como assinala CARVALHO DE MENDONÇA (1945).

Em verdade as sociedades civis podem assumir várias formas, mas basicamente ecerram uma atividade empresarial, com finalidade lucrativa que a lei reputa não comercial, como a construção civil, a pecuária, as atividades de profissão regulamentada, desde que não se revistam da forma de uma S/A . 


\section{Associações civis}

As associações civis diferem basicamente das sociedades civis em função da sua finalidade não lucrativa, ou seja, suas relações externas não consistem no fornecimento de bens e serviços de maneira empresarial. Apenas eventualmente podem estar provendo bens e serviços porém em caráter altruístico, do contrário sua finalidade pode se resumir na busca de algum valor social de interesse de toda a coletividade ou simplesmente de interesse de seus associados. Internamente também não ocorre qualquer fornecimento de bens e serviços no sentido que fazem as cooperativas. As trocas internas são juridicamente neutras. Embora não haja distinção legal entre sociedade civil e associação civil, tal distinção decorre da doutrina e da jurisprudência, com base tanto no aspecto do intuito de lucro quanto no que diz respeito à sua abertura ao público, ou seja, as associações civis mantém o seu caráter e propósito a despeito do ingresso ou saída de algum membro.

\subsection{Prós e contras da personificação}

Outro aspecto importante diz respeito à criação de uma terceira figura, uma pessoa fictícia ou pessoa jurídica a fim de consubstanciar uma Organização Virtual.

Segundo MENDONÇA ${ }^{5}$ apud ALMEIDA (1998), decorrem da personificação as seguintes conseqüências relevantes ao direito:

- Capacidade de determinar-se e agir para defesa e consecução dos seus fins, por meio dos indivíduos que figuram como seus órgãos;

- Patrimônio autônomo, isto é, não pertencente a nenhum dos indivíduos que a compõem;

- Obrigações ativas e passivas a seu cargo exclusivo;

- Representação em juízo. 
Nenhum dessas consequiências constitui propósito a ser almejado pela OV. Ao contrário, o que se pretende com a OV é apenas predispor os membros e ajustá-los internamente. Os aspectos acima destacados estão diretamente relacionados com a vida exterior da entidade.

A personificação, por si só pressupõe uma relação duradoura, e muitas vezes, ao tempo de sua total materialização, várias oportunidades de negócios podem estar sendo desprezadas, ou atendidas de maneira precária. É evidente que se a parceria virtual ocorre para ser dissolvida tão logo sejam cumpridas as metas ou atendida a demanda, da nova pessoa jurídica criada para aquele fim restaria apenas uma carcaça, inútil e onerosa.

A opção que se faz neste trabalho, é pela não personificação, ou seja, não se vislumbra a princípio a necessidade de criação de um terceira entidade dotada de capacidade jurídica. Almejar o reconhecimento estatal de sua existência não é essencial, a não ser que se pretenda algum tipo de relacionamento específico com o próprio Estado, ou por exigência de algum cliente em particular seja personificação requisito indispensável. Sua necessidade portanto é apenas eventual ou episódica. De outro lado, personificar significa lançar mão de certo formalismo, não significando qualquer violação ao conceito Organização Virtual.

Em que pese o paradoxo, é possível ainda, dotar o contrato em questão, de mecanismos que permitam sua rápida adaptação à exigências legais para fins de registro nos órgãos competentes, a fim de que o Estado reconheça a personalidade e lhe atribua capacidade jurídica.

\footnotetext{
${ }^{5}$ MENDONÇA, J.X.C.(1961). Código Civil Brasileiro Interpretado, $7^{a} \mathrm{ed}$.
} 
É possível entretanto, que em face da necessidade de relacionamento com agências públicas de fomento, com Universidades etc., se faça indispensável a identificação formal de um representante legal, um domicílio sede), uma denominação, enfim um contrato formalmente registrado perante as repartições competentes. Nessa linha de raciocínio, afigura-se necessário dispor de mecanismos legais que atendam a essas demandas, inclusive, conforme o caso para obtenção de certificação das séries ISO, mas que ao mesmo tempo não invalide ou impeça a ocorrência das EVs com todas as suas características. É o que se procurará demonstrar nos tópicos subsequentes.

Optar pela não personificação traz como conseqüência externa a ausência de capacidade de ser titular de direitos conforme já se descreveu linhas atrás, e internamente, a existência de um contrato, porém sem seu competente registro, faz com que a entidade se transforme não apenas numa associação de fato, mas em algo que lhe é superior, ou seja uma associação meramente irregular, sendo que a distinção entre uma e outra, é que o ato constitutivo da sociedade irregular serve como elemento de prova entre os sócios, aspecto que nos interessa sobremaneira. Porém do ponto de vista das relações externas, com ou sem documento escrito e assinado, ambas as sociedades, de fato ou irregular, possuem o mesmo conjunto de responsabilidades perante terceiros que com ela contratem. Vale dizer que ações podem ser movidas contra a sociedade ou seus sócios, respondendo estes últimos solidaria e ilimitadamente pelas obrigações sociais. Porém, como a OV não se destina a efetuar trocas mercantis com o meio externo, esse aspecto se torna irrelevante. Entretanto para fins de configuração de uma EV, é fundamental estabelecer mecanismos de compensação de prejuízos, uma vez que a EV será para todos os efeitos uma sociedade de fato, e a luz da nossa legislação a responsabilidade é solidária, ou seja, estende-se para todos os membros independentemente da efetiva contribuição para os danos e pelo valor integral do prejuízo. 


\subsection{Modelo mais adequado de personalidade}

Apesar de toda sorte de inconvenientes advindos da personificação, nada obsta que se tenha, previamente à criação de uma EV, um ambiente estável e seguro a partir do qual os parceiros possam se articular rápida e informalmente para atender a uma oportunidade de negócio. Esse perspectiva nos remete necessariamente ao conceito de OV. Com efeito, a estrutura da OV deve ter mecanismos elaborados para suportar o processo de coordenação dos membros, de acordo com as diferentes perspectivas a serem encontradas. A formalização destes mecanismos traz maior transparência na relação entre os parceiros e consequentemente atua nos fatores sócio culturais relevantes ao sucesso do empreendimento (KOCIAN, 1997). Consequentemente, uma Organização Virtual pode servir como base para a implementação de mecanismos para a formação e gerência de EVs.

Tendo em conta que uma OV é "uma rede estável de empresas, destinada a formação de Empresas Virtuais, interligadas de acordo com suas competências essenciais e estratégias de mercado e suportada pela utilização da tecnologia de informação" (KOCIAN \& SCHEER, 1996), empecilho não há quanto à sua estruturação em torno de um contrato que tenha por escopo, além da cooperação, atender à exigências legais atinentes à personificação. Ao contrário, mostra-se útil e desejável que a OV disponha desse mecanismo jurídico. Ainda que de imediato não se almeje a personificação, a estabilidade da rede e a segurança reclamados, só podem ser conseguidos, conforme já se demonstrou linhas atrás, quando da distinção entre ética e direito, através de um contrato bem detalhado definindo as regras de comportamento das empresas participantes. 
Uma vez que se opte pela personificação, a tarefa seguinte é encontrar, dentre os modelos legalmente aceitos na nossa legislação, aquele que de melhor maneira atenda aos requisitos tanto da OV que se está a criar, quanto das EVs que em seu bojo serão desenvolvidas, para então promover as adaptações que se fizerem necessárias, dentro do princípio da livre contratação e respeitados os limites legais.

Pelo que se conclui do item 4.1 retro, a associação civil apresenta-se como melhor alternativa de enquadramento para uma OV, seja pela sua natureza eminentemente civil, seja pela sua falta limitada finalidade com o meio externo, seja pela flexibilidade de abertura e acesso a qualquer membro, seja pelo pouco peso de exigências burocráticas, ou ainda pela compatibilidade de seus objetivos com a permissibilidade legal.

\subsection{Enfrentamento do tema no nível teórico em outros países}

A relativa novidade do tema, especialmente em termos de ausência de enquadramento legal, também é verificável na Alemanha. As alternativas discutidas pela doutrina naquele país seguem a mesma linha de raciocínio expendido neste trabalho, inclusive por tratarem-se de sistemas legais de mesma origem e serem as leis civis e comerciais brasileiras, em boa parte, inspiradas nos esquemas e tipologias alemães.

Como efeito, as formas societárias civis admitidas pela legislação alemã podem ser divididas fundamentalmente em Personengesellschaften, que eqüivaleria a nossa sociedade de pessoas, Kapitalgesellschaften, equivalente a uma sociedade de capitais e pessoas e Verein, equivalente a uma associação civil com estrutura corporativa, abertas ao ingresso de 
qualquer um com deliberação pelo regime de maioria. Os artigos 705 e seguintes do Código Civil Alemão define a sociedade civil - a forma básica das sociedades de pessoas (Personengesellschaften)- de forma bastante flexível, com uma regulamentação bastante aberta, sem requisitos formais e obrigações contábeis, segundo observa BERWANGER (1999).

Por outro lado, assim como ocorre no Brasil, uma sociedade civil ainda que livre de maiores formalidades, pode se transmutar em comercial, bastando para isso, que pratique atos de comércio com terceiros. De acordo com o parágrafo primeiro do Código Comercial alemão, cada tipo de empresa comercial corresponde a uma prática reiterada de atos de comércio pré definidos. Entretanto, uma sociedade deixa de ser comercial se não fizer uso da forma societária pré definida ou não praticar atos tipificados como comerciais.

Uma Organização Virtual por si só não oferece serviços de marketing ou efetua trocas comerciais com o meio externo. Como os membros de uma organização virtual coordenam sua participação em unidades de performance, as trocas são efetuadas em termos de parceria interna. Externamente a essa conexão eles devem trabalhar juntas exclusivamente como consumidores e como uma comunidade de proprietários; cada um isoladamente pode comprar a técnica da rede para a executar sua missão face à oportunidade de negócio surgida. Por essa razão, basicamente uma OV não tem um negócio específico estabelecido e se afigura como uma simples sociedade civil sem nenhum efeito legal no mundo externo.

No que concerne à natureza jurídica da Organização Virtual, mutatis mutandis a lógica opera no mesmo sentido, tanto num país quanto no outro, devendo prevalecer em linhas gerais a melhor adequação em torno de uma associação civil. Porém, as oportunidades de negócio que serão exploradas por meio de Empresas Virtuais, vistas estas como unidades de performance, passarão a agir diretamente como o mercado, realizando trocas mercantis, prestando serviços etc. A partir deste ponto merecem ser ressaltadas as alternativas propostas pelos doutrinadores alemães à luz das peculiaridades de sua legislação específica. 
Segundo observa BERWANGER (1999) uma unidade de performance surge particularmente em razão dos pedidos de um cliente. Para tal propósito alguns parceiros da rede virtual ou OV se agrupam e criam uma unidade de performance. Em função desse propósito comum, cada unidade de performance é uma sociedade; mas os objetos desse tipo de parceria são muito limitados. Uma unidade de performance é rápida e existe apenas temporariamente. $\mathrm{O}$ traço característico de uma unidade de performance é que ela depende de um interesse especial. Elas são denominadas associações ad hoc .

Associações ad hoc, segundo a mesma autora, não são expressamente reguladas pela lei alemã. Basicamente, de acordo com o seu tipo entretanto elas são parcerias civis. Esta seria a forma mais flexível e pode ser estabelecida e dissolvida informalmente e sem nenhum custo.

Típicas associações ad hoc são os grupos de trabalho na construção civil (ARGE), que receberam quase que uma padronização através de contratos-modelo dos sindicatos de construtores (BUCARDT \& PFÜLB, $1998^{6}$ apud BERWANGER,1999). De acordo com isso, uma ARGE, é uma união de construtores independentes que aceitaram certa empreitada, o que relembra a definição de uma unidade de performance.

Associações ad hoc também são chamadas "consórcio". Especialmente em construção de base e grandes projetos industriais existem consórcios que são uniões de várias empresas independentes, temporalmente limitadas (ORGALIME, 1995; ROSENER, 1997). Em contraste com uma ARGE, não usa máquinas ou materiais próprios e também não tem mão de obra em comum. Cada membro do consórcio fica com uma parte da tarefa e trabalha de forma independente tanto quanto possível. As máquinas e componentes elétricos de um sistema são construídos sem qualquer participação dos demais, pelo parceiro competente dentro de sua própria fábrica. Os módulos separados se encontram quando estão acabados e conectados. Essa junção de partes individuais de desempenho faz com que o consórcio seja bastante similar uma unidade de desempenho. 
Resumidamente, do ponto de vista das relações internas à uma OV, existem três modelos que comportam as chamadas unidades de performance, que para nós neste trabalho eqüivalem às EV : Associação ad hoc; ARGE - Arbeit Gruppe Ebauer; consórcio.

GORANSON (1995), ao propor um modelo de referência para empresas virtuais, reúne numa tabela todas as tomadas de decisão relevantes ao ciclo de vida da $\mathrm{EV}$, bem como aquilo que passou a denominar infra-estruturas, que em verdade são áreas de aplicação dentro de uma empresa. Dentre aquelas que assinala como relevantes, encontra-se a infraestrutura legal/explicita. Explicita no sentido de que "é articulada em algum lugar; isso inclui os processos que lidam com como o negócio está se desenvolvendo, quem administra quem, e que toma quais decisões. As regras que influenciam a descrição dos cargos estão incluídas,..."(GORANSON,1995, P. 128).

Dentro dessa infra-estrutura merecem destaque duas subinfra-estruturas: $\underline{\mathrm{O} \text { processo }}$ $\underline{\text { de negócio }}$, na medida em que trata entre outras coisas dos sistemas de risco/recompensa, supervisão e monitoramento e propriedade dos vários elementos da empresa, bem como o $\underline{\text { Regulamento }}$, que contempla os processos relacionados aos instrumentos legais, que internamente podem ser contratos e clausulas e externamente os códigos, leis e regulamentos.

Para fins do presente estudo tal distinção entre subinfra-estruturas é irrelevante uma vez que todas as questões suscitadas serão tratadas no bojo do mesmo instrumento legal.

Mais importante do que confirmar a relevância da infra-estrutura jurídica como peça fundamental do modelo teórico, nesse passo, é ressaltar que tipo de expectativa se tem em torno dessa infra-estrutura. Com efeito, GORANSON(1995) cita como exemplos de atributos dessa infra-estrutura que poderiam faze-la ágil, os seguintes:

- A habilidade para simultaneamente administrar diferentes modelos de cultura

- Uso de contratos - padrão baseados em precedentes (jurisprudência)

\footnotetext{
${ }^{6}$ BUCHARDT/ PFÜLB: ARGE Kommentar, 3. Auflage, Weisbaden 1998.
} 
- Proliferação de agentes para preencher exigências legais relativas à descobertas (patentes), certificação e indenização

- Flexibilidade dos contratos para poderem suportar a objetivos fluidos e flexíveis

- Flexibilidade na adequação ao tipo de cliente

- Flexibilidade na maneira como a propriedade intelectual é administrada durante e depois da atividade da EV

- Processo de dissolução pré determinado

Esses atributos desejáveis, obviamente não podem ser alcançados todos simultaneamente, apenas alguns desses aspectos podem ser otimizados, sob pena inclusive de comprometer o informalismo e a confiança tão propalados.

Observe-se que ao mencionar modelos de contratos baseados em precedentes, que para nós eqüivale à jurisprudência, o sistema jurídico referido é o americano, onde há a primazia dos já mencionados case law, em detrimento da lei. Entretanto, o socorro à jurisprudência não encontrará nenhum modelo específico para EVs. Sob a epígrafe de Virtual enterprise ou Virtual Organization até a corrente data não foram encontrados cases no nível das Cortes estaduais ou federais, através de busca nos mega-portais de legislação americanos, o que leva a crer que os contratos-padrão referenciados por GORANSON(1995) sejam aqueles contratos que já são típicos, como transferência de Know-How, licenciamento de patentes, comissão mercantil, etc.

Nos sistemas da common law, além de não existirem arquétipos legais aproveitáveis ou leis que estabeleçam fronteiras para esse modelo de parceria, há nos EUA uma grande variabilidade de regras em função dos denominados States statutes (normas adotadas em cooperação entre Executivo e Legislativo estaduais) que equivalem à legislação interna de um país soberano, não se submetendo à legislação federal americana, conforme observa 
SOARES (1999) . Disso resulta que os contratos são verdadeiros monumentos jurídicos, e por isso muito repudiados pela literatura americana quando propugna pela sua eliminação, sem contudo oferecer alternativa consistente. Exemplo dessa necessidade de redação muito extensa, prevendo todos os pormenores, pode ser encontrado nos aspectos relacionados ao risco do negócio. Lá são necessárias ressalvas expressas ao "caso fortuito" e "força maior" e as chamadas cláusulas hardship, todas elas destinadas a excluir, minimizar ou rever o contrato diante da impossibilidade de cumprimento integral ou parcial, segundo escólio de BATISTA (1994). Tal seria desnecessário nos sistemas filiados ao direito romanogermânico, como aqui, por força de prévia determinação legal, com comandos genéricos e abstratos, cabendo à jurisprudência fazer apenas o "ajuste fino" enquadrando o caso concreto à lei.

\subsection{Cluster como principal plataforma jurídica.}

À luz dos conceitos de OV e EV que foram extraídos da literatura referenciada neste trabalho, não é difícil perceber a necessidade de enfrentar o desafio lançado pelo novo paradigma, através da opção pela criação, em primeiro lugar, de redes de cooperação, a fim de proporcionar um maior estreitamento de vínculos entre os parceiros, seja no nível da alta administração seja no nível das tarefas mais simples.

É inegável a vantagem, para a formação de uma OV, que as empresas participantes já se encontrem de alguma forma agrupadas, seja em função de sua localização geográfica, de seu nível tecnológico, de suas atividades correlatas, de suas relações de complementaridade etc., especialmente quando se tem em mira fatores como conhecimento recíproco e confiança, indispensáveis para o empreendimento virtual. 
Embora a idéia de vantagem comparativa venha sendo mitigada por conta da globalização, paradoxalmente o que se constata segundo PORTER (1999), é que "a inovação e o sucesso competitivo em vários setores estão geograficamente concentrados - sejam o entretenimento em Hollywood e as finanças em Wall Street, sejam os produtos eletrônicos no Japão". Na esteira desse raciocínio, afirma que o mapa econômico do mundo é dominado hoje por aquilo que chama de cluster. E passa a defini-lo como sendo "concentrações geográficas de empresas de determinado setor de atividade e companhias correlatas. Estas podem ser, por exemplo, fornecedores de insumos especiais - componentes, máquinas, serviços - ou provedores de infra-estrutura especializada". Segue afirmando que os clusters se expandem diretamente em direção aos canais de distribuição e clientes e marginalmente em direção aos fabricantes de produtos complementares e empresas de setores afins. Em acréscimo, não descarta a participação de instituições governamentais, universidades, entidades normativas e associações comerciais, pela sua colaboração em informações, treinamento, pesquisa e apoio técnico.

Se por um lado essa multiplicidade de entidades participantes, muitas delas de natureza diversa, bem como essas diferentes direções nas quais seguem expandindo os clusters, oferecem ambiente adequado para o surgimento das OVs, por outro lado acrescem em embaraço para sua personificação jurídica.

PORTER (1999) não chega a afirmar que a personificação eqüivale à negação da idéia de cluster, entretanto reforça a idéia de que a proximidade física de empresas e instituições, assim como as sucessivas trocas entre elas, facilita a coordenação e amplia a confiança sem "impor às empresas as características de inflexibilidade da integração vertical ou os desafios de criar e manter associações formais como redes, alianças e parceiras".

O objeto deste trabalho consiste justamente no desafio mencionado, qual seja criar e manter uma associação formal, personificada ou não, reconhecendo a preexistência de um cluster e atribuindo-lhe condições para que em seu bojo as EVs ocorram em sua plenitude. 
A fim de que a proposta apresentada signifique uma verdadeira contribuição acadêmica e possa ser aproveitada como modelo de referência no Brasil, é indispensável reconhecer que embora existam inúmeras unidades de negócio com excelência mundial de pequeno e médio porte, estas simplesmente não se conhecem ou quando muito seu relacionamento é esporádico e se encontram afastadas geográfica e culturalmente. A superação desse entrave, com vistas à realização plena de uma EV, passa necessariamente pela consolidação de uma etapa anterior, ou estágio anterior, a que denominamos OV.

A figura 10, abaixo permite visualizar a relação de continência das empresas face à OV proposta, bem como sua montagem posterior no âmbito de uma $\mathrm{EV}$, as formas cilíndricas são representativas de estruturas jurídicas.



Figura 9 - Relação entre contrato de OV e contrato de EV 


\title{
4.6 Cláusulas que comportem a consolidação do Cluster bem como garantam agilidade e segurança aos processos de formação das Empresas Virtuais
}

\begin{abstract}
Além do aspecto formal do modelo de contrato, o conteúdo do contrato não pode prescindir de determinadas regras básicas indispensáveis que confiram ao cluster sua funcionalidade e atendimento à exigências das cooperações virtuais.
\end{abstract}

\subsubsection{Princípios que devem ser observados}

Do conjunto de valores culturais que peermeiam o relacionamento entre as empresas, alguns precisam ser melhor explicitados e elevados à condição de axiomas com vista à consolidação dos alicerces desse novo paradígma de parceria, sem os quais o empreendimento se inviabiliza. Conforme preleciona SILVA (1978), princípios jurídicos significam as normas elementares ou requisitos primordiais instituídos como base, como alicerce de alguma coisa. Nesse sentido revelam o conjunto de regras ou preceitos, que se fixam para servir de norma a toda espécie de ação jurídica, traçando assim, a conduta a ser tida em qualquer operação jurídica.

A inserção de tais valores como regras escritas, além de servir para consagrá-los explicitamente perante o meio externo, internamente serve de balisa para solução de conflitos e reveste os valores da coercitividade ausente no campo ético. São listados a seguir os mais importantes. 
Transparência - nenhum membro deverá ocultar suas dúvidas ou insatisfações com relação aos demais membros, devendo manifestar-se publicamente e na primeira oportunidade sobre seu inconformismo, evitando-se assim que surjam desconfianças e ressentimentos e que estes se propaguem de forma velada sobre todo o grupo.

Boa-fé - todo relacionamento, contratual ou não, entre os membros terá como pressuposto a boa-fé, ou seja, as aproximações e trocas de informação não podem ter outro objetivo que não a efetiva cooperação. $\mathrm{O}$ aproveitamento de informações estratégicas em causa própria, com ou sem prejuízo efetivo para os demais membros é inadmissível.

Não concorrência- Dependendo do tamanho a OV a ser formada convém que seja vedada a concorrência entre membros em termos de produto final, não o sendo, entretanto, em termos de competências essenciais.

Arbitragem- nenhum conflito entre os membros, em princípio deverá ser resolvido judicialmente, mas por arbitragem dos próprios membros, através do órgão de solução de controvérsias, exceto na hipótese em que as partes em conflito se tenham retirado da associação.

Cooperação pró-ativa- com vistas às parcerias futuras, os membros devem adotar comportamento pró-ativo, caracterizado pela criatividade, iniciativa, espírito empreendedor, excelência na atuação e confiança plena, de maneira a consolidar uma cultura de cooperação que se estenda inclusive aos empregados das empresas membro.

Informalidade- salvo nas hipóteses de negócios concretos com o mercado consumidor, as demais relações entre os membros poderão ser documentadas através de atas, memorandos e circulares que ensejarão as mesmas obrigações de um contrato formalmente celebrado. Na ausência destas, qualquer ajuste verbal deverá surtir o mesmo efeito, desde que presenciado por dois ou mais membros industriais. 
Confidencialidade- todas as idéias veiculadas por qualquer membro na busca da cooperação pro-ativa estarão protegidas por sigilo, não podendo ser divulgadas senão com expressa anuência de seu autor, ou quando da efetiva colocação dos produtos no mercado.

\subsubsection{A empresa líder como alternativa à não personificação}

Pela natureza jurídica da OV, na forma como está sendo concebida neste trabalho, não lhe é dado efetuar trocas comercias com o meio externo, como objetivo principal. Assim sendo, as relações comercias necessariamente têm que ser estabelecidas por alguma entidade dotada de personalidade jurídica - alguém que possa emitir notas fiscais, certificados de garantia dos produtos, figurar como autor ou réu em ações judiciais, etc.

Como as EVs , com muito mais razão, também não são concebidas para adquirirem personalidade, sob pena de ruptura com todos os pressupostos até aqui invocados, surgem dois caminhos a serem percorridos: ou o cliente na verdade é um grande distribuidor, daí então deverá participar da formação do contrato de EV assumindo todas as responsabilidades perante o meio externo, e aderindo a todas as regras que fazem parte da $\mathrm{OV}$, o que pode até culminar com a sua inclusão como membro; ou, se o cliente é o consumidor final, então necessariamente uma das empresas deverá assumir integralmente esse papel externo.

Assumir esse papel externo significa aparecer como fornecedor, respondendo pela qualidade do produto e continuidade do fornecimento de peças e manutenção e figurar como adquirente de matérias, emitindo títulos de crédito etc. Caso se trate de produtos tangíveis, ou seja bens corpóreos, na contabilidade da empresa líder deverá aparecer o estoque inicial de matérias primas e o estoque final de produtos acabados, ainda que depositados nas dependências (chão de fábrica) de terceiros. Toda movimentação de material deverá ser documentada com notas da empresa. Essa empresa é a que denominamos empresa líder. 
Quando do recebimento do preço pelos produtos vendidos, os lucros são divididos na medida do valor que foi agregado por cada empresa no processo produtivo, com base num critério de custeio previamente ajustado no plano de negócio. O recebimento dessas importâncias pelas empresas que participaram da EV será contabilizado como receita proveniente de prestação de serviço ou de venda de materiais, dependendo da natureza de sua participação, se como beneficiador, ou montador com acoplagem de peças e componentes. A Figura 11 procura demonstrar esse papel .

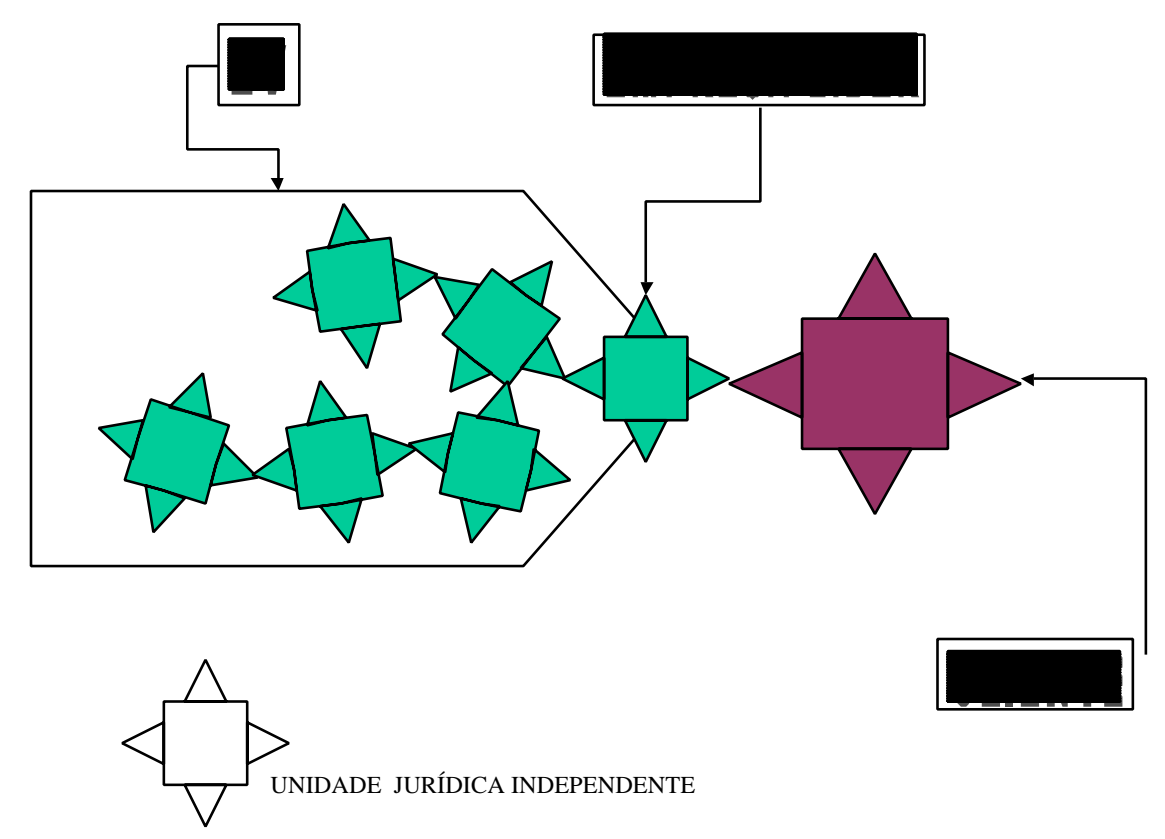

Figura 10 - O papel da empresa líder

Dois exemplos de assunção desse papel podem ser citados, um nos EUA e outro no Brasil, ressalvando desde já que são modelos onde há uma hegemonia da empresa lider e uma delegação de tarefas, mediante compra de competências, o que não deixa de ser uma modalidade de empresa virtual.

O primeiro a é o da Lewis Galoob Toys, citado por GOLDMAN et al. (1995): 
"Trata-se de uma empresa americana que produz brinquedos e tem mais de cem empregados, com um faturamento de 50 milhões de dólares. Esta empresa compra idéias de produtos de inventores independentes e deixa o desenvolvimento para escritórios de engenharia também independentes. A produção em si acontece através de sub-contratação de empresas em Hong Kong, que por sua vez transferem grande parte do trabalho para a China por razões de custo de produção. Os produtos acabados são transportados por expedidores até os EUA e lá vendidos por representantes independentes. Mesmo funções como controladoria e contabilidade são realizadas por empresas externas. A Gallob restringe-se portanto ao núcleo de gerenciamento (ou liderança estratégica) desta rede de empresas independentes, mas aparece como empresa líder. A Galoob foi considerada por determinados observadores como sendo uma "...very alien business creature" (uma criatura de negócios deveras incomum).

Outro exemplo é o da Publifolha, referenciado por BREMER (2000).

A Publifolha é uma unidade de negócio do Grupo Folha, assim como o Datafolha, a Agência Folha, e a Transfolha, todos compartilhando os recursos de marketing, jurídico, infra-estrutura básica, etc., em um formato de 'condomínio'. Esta unidade conta atualmente com 28 pessoas no staff, distribuídas nas funções de gestão do conteúdo / produto, administração / finanças e comercial / marketing.

Em termos de sustentação financeira, a Publifolha é vista como uma unidade de negócios do grupo Folha já autosustentável e comercializa seus produtos sem utilizar consignação, ou seja, não trabalha com retorno de material que não foi vendido no comércio, o que tornaria complexo gerenciar este custo de não venda entre todos os parceiros envolvidos. A opção é produzir o que vai ser vendido. 
A organização do sistema de parcerias segue a estratégia da unidade em concentrar-se na gestão dos produtos. Ou seja, na produção de qualquer item das linhas de produto, seja um livro, vídeo ou CD-ROM, há a necessidade do desenvolvimento de uma matriz para a posterior fabricação em série do produto. Assim, de acordo com a estratégia da Publifolha, as parcerias são realizadas na fase de pré-matrizes, e todo o processo pós-matrizes é responsabilidade da Publifolha, mesmo que seja realizado por outras empresas via terceirização.

Neste ponto, nota-se que a rede de parcerias da Publifolha ocorre de uma maneira inversa à realizada por exemplo no setor automotivo, onde as montadoras concentram as competências do produto como um todo, delegando apenas pequenas partes às cadeias de seus fornecedores. Já neste caso, a criação do produto pode partir tanto de parceiros, como se originar de uma idéia da Publifolha que procura um parceiro para desenvolvê-la. Contudo todo o processo de gestão do produto é responsabilidade da Publifolha, conforme a estratégia de focar em marketing, design, fabricação, comercialização e distribuição.

Os parceiros podem ser classificados em parceiros de produção, de conteúdo e complementares, os quais são especificados a seguir.

Parceiros de Produção: São constituídos de birôs de editoração, pequenas editoras e pequenas oficinas de publishing conhecidas como garage companies. Tais parceiros concentram seus serviços na área pré-matriz, fornecendo competências de design, editoração, tradução, textos, fotos, ilustrações, consultoria conceitual. São as de maior envolvimento com o pessoal interno da Publifolha, são mais duradouras, no sentido de que podem continuar existindo como parceiras por vários produtos em execução, requerem uma significativa confiança entre as duas partes envolvidas, uma vez que é necessário ampla troca 
de informações técnicas e comerciais, sendo difícil e demorado detalhar todos estes aspectos, ou todos os detalhes do relacionamento com este tipo de parceiro, na proteção jurídica de um contrato. Na área pós-matriz, os parceiros de produção são grades empresas, tais como: gráficas, duplicadoras de CDs e CD-ROMs, fabricantes de fitas de vídeo, empresas de embalagem e de manuseio (assembling).

Parceiros de Conteúdo: São os que fornecem competência para o conteúdo do produto, como a parceria com a Dorling Kindersley para a produção em português dos Guias Visuais. Fazem parte deste grupo também várias pequenas editoras e oficinas de publishing, que levam seus projetos à Publifolha, visando oportunidades específicas de negócio para serem desenvolvidos conjuntamente, uma vez que as mesmas não teriam condições de bancarem todo o processo de desenvolvimento e produção isoladamente. Neste tipo de parceria, também há necessidade de grande envolvimento, e também há conflitos a ser gerenciados. Por exemplo: o parceiro quer estender mais o conteúdo, mas isso atrasaria o projeto. É necessário então discutir e obter um consenso uma vez que o parceiro, principalmente quando o projeto vem dele, não poderá aceitar uma mudança de conteúdo se não estiver de acordo. Outro tipo de conflito a ser gerenciado, especialmente quando o Publifolha está financiando o projeto: o parceiro tende naturalmente a adotar o ritmo que achar conveniente; já a Publifolha tem que procurar respeitar seu planejamento de lançamento de produtos. Os gerentes da Publifolha intervem em busca do consenso, uma vez que, quanto melhor lançado um produto (na época certa), melhor para as duas empresas.

Parceiros Complementares: São os parceiros que dão suporte à parte comercial da Publifolha. Existem parcerias com empresas de televendas e helpdesk, que abrangem os setores de vendas e pós-vendas, este último no caso específico da linha de multimídia. Há ainda uma parceria de logística com os Correios, que funcionam ao mesmo tempo como centro de estoque e distribuição. Estas parcerias são administradas via contratos, não havendo maiores complexidades no gerenciamento deste relacionamento. 


\subsubsection{A responsabilidade solidária}

A fim de se evitar conflitos acerca da qualidade dos produtos que são colocados no mercado, bem como dos riscos e danos experimentados pelos consumidores, é necessária a delimitação da responsabilidade de cada membro que venha a participar de uma EV, especialmente tendo em conta que de acordo com o modelo adotado, perante o mercado figurará apenas uma das empresas membro que denominamos empresa líder.

Solidariedade significa a concorrência de mais de um credor ou devedor numa mesma obrigação, cada um com direito ou obrigado à dívida toda. A regra geral que prevalece no direito brasileiro é a de que a solidariedade não se presume, decorre da lei ou da vontade das partes(C.C. art. 896).

No tocante às obrigações decorrentes da responsabilidade como fornecedor, cumpre esclarecer que o Código de Defesa do Consumidor é bastante avançado, tendo ampliado sobremaneira os mecanismos de reparação de danos, dentre eles pode-se destacar os seguintes:

口 Possibilidade de entes despersonalizados serem reputados fornecedores para serem alcançados pela lei( $\left.\operatorname{art} .3^{\circ}\right)$.

口 Inclusão de bens imateriais na definição de produto.(art. $\left.3^{\circ}\right)$

- Responsabilidade objetiva(independente de culpa) do fabricante, do produtor, do construtor e do importador, por produtos com defeitos decorrentes de projeto, fabricação, construção, montagem, fórmulas, manipulação, apresentação ou acondicionamento, bem como por informações insuficientes ou inadequadas sobre sua utilização e riscos(art.12).

a Responsabilidade solidária do fornecedor pelos vícios de quantidade e qualidade que impossibilitem a utilização do produto ou resultem em diminuição do valor(art.18). 
- Responsabilidade solidária do fabricante, construtor ou montador, por dano causado por peça defeituosa incorporada ao produto(art. 25).

- Possibilidade de desconsideração da personalidade jurídica pelo judiciário, para responsabilizar os titulares da empresa, quando houver abuso de direito, ilicitude, violação do contrato social ou falência(art. 28).

Como se vê, a luz do direito do consumidor, a solidariedade é uma imposição legal, de tal sorte que o consumidor pode demandar contra um ou contra todos os integrantes de uma EV. Como o modelo proposto, entretanto, dá maior relevo à empresa líder, e é esta quem efetivamente aparecerá ao mercado, é natural que eventuais ações judiciais sejam contra ela propostas em primeiro lugar. Por tal razão, caso o parceiro efetivamente responsável pela má qualidade de um produto ou por qualquer outro dano causado aos consumidores, não venha a ser demandado, é indispensável prever através do contrato esse liame obrigacional. Colocando o infrator na condição de garante, para reparar de pronto os prejuízos, inclusive na esfera judicial. Percebe-se de outro lado, que não dispor de personalidade jurídica, para fins de defesa do consumidor é indiferente. Ou seja, quem estiver de alguma forma ligado à produção e fornecimento de produtos será igualmente responsável. De outro lado, ter personalidade jurídica não impede que os criadores dessa terceira figura, sejam eles pessoas físicas ou outras pessoas jurídicas, venham a ser responsabilizados.

A solidariedade no fornecimento bem como a irrelevância da personificação constituem a tônica da LEI 8.078 DE 11/09/1990 - Código de Defesa do Consumidor(CDC). A título de exemplificação da abrangência desses dispositivos temos a seguinte manifestação do Tribunal de Justiça de São Paulo: 




No acórdão acima observa-se claramente a responsabilização objetiva da fabricante, ou seja independentemente de aferição de culpa, pelo simples fato de expor o consumidor ao risco.Numa $\mathrm{EV}$, a empresa que figurar como produtora perante o mercado poderá ser demandada em hipóteses como esta, sem ter concorrido com qualquer culpa, não se revelando justo, portanto, que venha a suportar sozinha os ônus decorrentes de uma condenação.

Por isso é importante estabelecer previamente um ajuste no sentido de serem partilhados os prejuízos.

De fora as relações de consumo, nos demais casos, porém, especialmente os relacionados com operações de crédito na aquisição de insumos, serviços de terceiros, etc. , prevalece a regra geral, ou seja, a solidariedade tem que decorrer da vontade das partes. 
Nesse sentido, é importante que as empresas envolvidas numa EV, assumam solidariamente essas obrigações. Tendo em conta o valor a ser agregado no produto final bem como a respectiva fatia nos lucros, essa solidariedade deve ser proporcional a esses valores. Existem mecanismos legais para tal, é o caso dos avais parciais. "O aval é o ato cambiário pelo qual uma pessoa(avalista) se compromete a pagar título de crédito, nas mesmas condições que um devedor desse título" (COELHO,1998,P.402). Segundo ALMEIDA (1998), aval parcial, também chamado aval limitado, restringe-se quanto à soma a ser paga, e está expressamente previsto na Lei Uniforme de Genebra, art. 30: "o pagamento de uma letra pode ser no todo ou em parte garantido por aval".

\subsubsection{A arbitragem como instrumento à favor da agilidade}

Um dos mecanismos essenciais a serem contemplados no contrato de OV, especialmente destinados à manutenção do "equilíbrio" e da "adaptabilidade" da organização, naquele sentido sistêmico reportado no Cap. 3, é a instituição da arbitragem.

Muito embora constitua tema aparentemente moderno, sua origem remonta os primórdios de Roma. Segundo preleciona CARMONA (1997), no período da Realeza a figura do pretor se resumia a preparando a ação, primeiro mediante o enquadramento na ação da lei e, depois, submetendo o julgamento a um iudex ou arbiter, que não integrava o corpo funcional romano, mas era simples particular idôneo, incumbido de julgar. Segundo o mesmo autor, "esse arbitramento clássico veio a perder força na medida em que o Estado romano se publicizava, instaurando a ditadura e depois assumindo, por longos anos, o poder absoluto, em nova relação de forças na concentração do poder, que os romanos não mais abandonaram até o fim do Império. Nesse novo Estado romano, passa a atividade de composição da lide a ser completamente estatal. Foi nesse contexto, que surgiu a figura do juiz como órgão estatal. E com ela a jurisdição em sua feição clássica, poder-dever de dizer o direito na solução dos litígios. 
A arbitragem, que em Roma se apresentava em sua modalidade obrigatória, antecedeu, assim, à própria solução estatal jurisdicionalizada.

Com as naturais vicissitudes e variações históricas veio ela também a decair de importância no direito europeu-continental, ou civil law, persistindo forte a técnica de composição puramente estatal dos conflitos. Mas subsistiu como técnica, em razoável uso, paralelamente à negociação e à mediação, no âmbito do common law, o direito angloamericano - marcado por profunda influência liberal, fincada no empirismo de Francis Bacon e de juristas do porte de Blackstone, Madison, Marshal, Holmes e Cardozo, aos quais jamais seria infensa a utilização de válida forma de solução de litígios, como o arbitramento -, até chegar aos tempos contemporâneos, em que retoma força e passa a ser verdadeiro respiradouro da jurisdição estatal..." (CARMONA,1997,P.46).

Com efeito, a arbitragem tenha sido contemplada no vetusto Código Comercial Brasileiro bem como no atual Código de Processo Civil, seu uso foi bem pouco difundido entre particulares no direito interno, especialmente pela fragilidade e não obrigatoriedade das cláusulas arbitrais e necessidade de homologação do laudo arbitral pelo Poder Judiciário. Apenas recentemente é que esse instituto foi revitalizado mediante reforma legislativa. $\mathrm{Na}$ esteira de pressões do mercado face a morosidade e percalços inerentes à ações judiciais é que foi promulgada a Lei $\mathrm{n}^{\circ}$ 9.307, de 23 de setembro de 1996. São oferecidos matizes novos ao instituto, procurando torná-lo mais eficaz e apto a atender as necessidades de hoje.

Três são os pontos que devem ser salientados como novidades relevantes na Lei:

a) a irrecorribilidade da sentença arbitral;

b) a dispensa de homologação da sentença pelo Judiciário, para emprestar-lhe executividade;

c) a revogação do inciso VI do art. 51 do Código de Defesa do Consumidor. 
Como ressaltou o parecer da Comissão de Constituição, Justiça e Cidadania do Senado Federal, "... A irrecorribilidade da sentença arbitral não viola o princípio constitucional da ampla defesa. ... A sentença arbitral tem efeito, força de coisa julgada entre as partes. A arbitragem é instituto de natureza contratual e as partes, que livremente e de comum acordo, instituírem o Juízo Arbitral, não podem romper o que foi pactuado".

Ao dispensar, por outro lado, a homologação, a lei confere força executória à sentença, equiparando-a à sentença judicial transitada em julgado.

Finalmente, revoga-se o inciso VI do art. 51 da Lei $\mathrm{n}^{\circ}$ 8.078/90 (Código de Defesa do Consumidor). Por esse inciso eram nulas, de pleno direito, as cláusulas contratuais relativas ao fornecimento de produtos e serviços que determinem a utilização compulsória da arbitragem. Como frisou a referida Comissão, ao propor a revogação do inciso, não se deixa ao desamparo o consumidor, pois, no $\S 2^{\circ}$ do art. $4^{\circ}$ da Lei de Arbitragem se estabelece que nos contratos de adesão a cláusula compromissória só terá eficácia se o aderente tomar a iniciativa de instituir a arbitragem, ou concordar, expressamente, com sua instituição.

Essa reforma legal, conquanto não seja recente, é muito nova do ponto de vista de formação de jurisprudência e utilização prática. Entretanto, para as relações comerciais, especialmente aquelas havidas em ambiente de alta tecnologia, afigura-se muito mais seguro optar por soluções arbitrais, tiradas por pessoas idôneas do próprio meio, do que submeter-se ao formalismo e morosidade característicos do Poder Judiciário, onde talvez nem haja vivência técnica suficiente para melhor visualizar os verdadeiros contornos do litígio.

A cláusula arbitral é o mecanismo de acesso à arbitragem, e uma vez definido o árbitro ou o órgão responsável pela arbitragem e as regras procedimentais, a arbitragem pode ter início sem maiores delongas. Num ambiente em que se exige agilidade, confiança e sobretudo sigilo a arbitragem representa um eficaz suporte, tanto para solucionar questões no âmbito da OV, mas sobretudo para funcionar como mecanismo de compensação durante os processos de formação, funcionamento e dissolução das EVs. Afigura-se importante neste passo transcrever os principais dispositivos do mencionado dispositivo, Lei 9307/96: 
ART.1 - As pessoas capazes de contratar poderão valer-se da arbitragem para dirimir litígios relativos a direitos patrimoniais disponíveis.

ART.2 - A arbitragem poderá ser de direito ou de eqüidade, a critério das partes.

$\$ 1$ - Poderão as partes escolher, livremente, as regras de direito que serão aplicadas na arbitragem, desde que não haja violação aos bons costumes e à ordem pública.

ART.4 - A cláusula compromissória é a convenção através da qual as partes em um contrato comprometem-se a submeter à arbitragem os litígios que possam vir a surgir, relativamente a tal contrato.

$\$ 1$ - A cláusula compromissória deve ser estipulada por escrito, podendo estar inserta no próprio contrato ou em documento apartado que a ele se refira.

ART.5 - Reportando-se as partes, na cláusula compromissória, às regras de algum órgão arbitral institucional ou entidade especializada, a arbitragem será instituída e processada de acordo com tais regras, podendo, igualmente, as partes estabelecer na própria cláusula, ou em outro documento, a forma convencionada para a instituição da arbitragem.

ART.7 - Existindo cláusula compromissória e havendo resistência quanto à instituição da arbitragem, poderá a parte interessada requerer a citação da outra parte para comparecer em juízo a fim de lavrar-se o compromisso, designando o juiz audiência especial para tal fim.

$\S 7$ - A sentença que julgar procedente o pedido valerá como compromisso arbitral.

ART.18 - O árbitro é juiz de fato e de direito, e a sentença que proferir não fica sujeita a recurso ou a homologação pelo Poder Judiciário.

ART.31 - A sentença arbitral produz, entre as partes e seus sucessores, os mesmos efeitos da sentença proferida pelos órgãos do Poder Judiciário e, sendo condenatória, constitui título executivo.

\subsubsection{O "pré-contrato" e as "condições"}

Uma vez estabelecida a plataforma sobre a qual deve se assentar a $\mathrm{OV}$, cumpre investigar e determinar os mecanismos que irão permitir que as EV ocorram no seu conceito mais puro, levando em conta as regras previamente estipuladas para os parceiros. Para tanto, alguns conceitos são apresentados. 
Sob a denominação de pré-contrato, contrato preliminar, promessa de contrato, compromisso ou contrato preparatório, insere-se uma categoria jurídica, distinta do respectivo contrato definitivo. Sua função consiste em criar a obrigação de celebrar o contrato definitivo, nas palavras de é a "convenção pela qual as partes criam em favor de uma delas, ou de cada qual, a faculdade de exigir a imediato eficácia de contrato que projetaram" (GOMES, 1979, p.149)

Segundo o mesmo autor, duas teorias principais explicam a natureza do pré contrato. Para a primeira é o contrato que tem por fim obrigar as partes a celebrar o contrato. Para a segunda, o contrato de execução subordinado a vontade de um ou dos dois contratantes, para que outro produza seus normais efeitos.

No caso específico de uma OV, a visão que se pretende imprimir é justamente a da segunda corrente, ou seja, dentro do próprio contrato do cluster, um conjunto de regras que tenham como finalidade estabelecer as condições gerais em que as EV e seus respectivos contratos vão ser executados. Condicionar, por exemplo, a solução dos conflitos existentes no âmbito de uma EV, ao órgão de solução de controvérsias por arbitragem, garantido que os conflitos não serão submetidos ao Judiciário.

Em linhas gerais o que ocorre com um pré contrato ou pactum de contrahendo é que o contrato futuro somente se concluirá se uma das partes o quiser, eis que é livre para descumprir em se sujeitando ao pagamento de perdas e danos. Ocorre porém que as EVs com relação ao contrato de cluster figuram como um evento futuro e incerto. Quando uma obrigação se condiciona a um evento futuro e incerto ela se denomina "condição". A promessa de contrato, tanto unilateral como bilateral, pode subordinar-se à condição ou termo, sendo essencial um intervalo entre a estipulação e a eficácia. A estipulação ocorre no momento em que um membro adere aos estatutos ou contrato de cluster e a eficácia ocorre no momento em que uma EV se forma. 
A condição é considerada um dos elementos acidentais dos atos jurídicos, em oposição àqueles considerados essenciais. Os primeiros se subordinam à vontade soberana das partes, os segundos decorrem de exigências legais; enquanto uns são facultativos, outros são obrigatórios respectivamente.

Conquanto a condição se caracterize como elementos meramente facultativos, "em unidade orgânica nos atos jurídicos se integram, modificando-lhes os seus efeitos" (RAO, 1994,p.243.). É uma modalidade voluntária de mecanismo que subordina o começo ou o fim dos efeitos dos atos jurídicos, à verificação de um evento futuro e incerto. Como depende exclusivamente da vontade a sujeição dos efeitos do ato jurídico, ela não é presumível, ou seja, deve ser consignada por expresso, de tal sorte que quem a invoca deve prová-la. Observe-se como nesse caso a Lei figura necessariamente como superestrutura, impondo às partes contratantes uma conseqüência importante sobre um mecanismo que em princípio é de liberdade das partes ajustar. Em outras palavras, se não houver um ajuste por escrito vinculando os efeitos do ato jurídico a um evento futuro e incerto, mesmo que presumivelmente as partes assim o desejassem, o início o fim dos efeitos daquele ato não poderia ser imposto a qualquer um dos que participassem de sua formação.

Esse aspecto torna-se crítico para as EVs, na medida em que se torna necessário desenhar mecanismos válidos que vinculem os integrantes de uma OV a toda uma sorte de regras previamente concebidas, para valerem no exato momento em que alguma parceria estiver efetivamente sendo entabulada. Ou seja, para nós, o evento futuro e incerto é a própria ocorrência de uma EV.

Transportar as regras de arbitragem, sigilo, etc. para o âmbito de uma EV, consiste precisamente em criar um ato jurídico condicionado. O compromisso de contratar uma parceria já se encontra desenhado, naquilo que se denomina pacto de contrahendo. É um conjunto de regras latente, cujos efeitos se produzirão no exato momento da ocorrência do evento futuro e incerto. Este tipo de condição denomina-se condição suspensiva, onde o início da eficácia do ato jurídico se subordina à verificação do evento futuro e incerto. 
A doutrina ainda divide a condição em outras categorias. Segundo RAO 1994), elas podem ser agrupadas em casuais, potestativas ou mistas. Casuais são aquelas em que a verificação do evento não depende da vontade daquele cujo direito à condição se subordina. Potestativas são aquelas cuja verificação do evento dependa da vontade da parte. E mista, aquela cuja verificação depende em parte da vontade e em parte do acaso, ou da vontade de terceiros. Esta última modalidade é a que mais de perto se relaciona com as EVs, cuja ocorrência depende da oportunidade do negócio bem como do desejo daqueles que se sintam aptos a participar.

A validade do pré - contrato requer observância das exigências legais quanto à capacidade das partes, ao objeto e a forma relativas, também ao contrato projetado.

Quanto à forma, há controvérsia. Para alguns deve ser autônoma em relação à do contrato definitivo. A utilidade prática do pré - contrato residiria, precisamente, nessa liberdade de forma. Entendem outros, todavia, que deve ser a do contrato definitivo, se esta for solene, pois do contrário, se iria contra a finalidade das normas que impõe a forma. A forma, no contrato preliminar, também possui função constitutiva, quando imposta como essencial à validade do negócio principal. Segundo GOMES(1979), "entre nós prepondera a orientação de validar o pré-contrato celebrado por instrumento particular, embora seja solene o contrato definitivo".

Como se pode notar a idéia central que está por detrás da montagem do contrato do cluster, é justamente permitir que os contratos de EV ocorram de maneira mais fluida possível, projetando no futuro toda eficácia das regras avençadas por escrito através daquilo que se denominou anteriormente como condição. 
Nesse sentido é importante relembrar que os contratos que estarão estruturando as $\mathrm{EV}$, envolverão uma multiplicidade de contratos típicos do ponto de vista interno à $\mathrm{OV}$, tais como licenciamento de patentes, transferência de Know-How, depósito, comodato, prestação de serviços, engineering, etc., todos eles ligados pelo mesmo propósito, qual seja o atendimento de uma oportunidade específica de negócio. Esses contratos todos que na verdade têm como propósito único o atendimento de um cliente situado além das fronteiras da OV, são compreendidos pela doutrina como contratos coligados.

Dessa forma, assume crucial importância o momento da criação da EV, que na ótica de REID et al. (1996), é a segunda etapa, posterior à da concepção, e consistiria no estabelecimento de relações entre os parceiros. Segundo ele, nesta fase, os parceiros irão desenvolver e implementar novos processos e sistemas que suportarão as demais etapas do ciclo. A EV é desenhada detalhadamente e é feita uma preparação completa para sua implementação. Aqui começam efetivamente as responsabilidades dos parceiros e nesse momento é que deve ser submetido aos representantes legais o plano de negócios para aprovação unânime.

\subsection{Os Contratos de Ev - Multiplicidade de Modelos e Finalidades - Comércio e Eletrônico e a Lei Uniforme Uncitral}

\subsubsection{Contratos mistos e coligados}

Se a ordem jurídica assegura aos indivíduos a liberdade de estruturação dos contratos, o número dos que podem ser estipulados à margem do paradigma legal é, por assim dizer, infinito. Haverá tantos quantos possíveis as combinações e os interesses dignos de proteção jurídica. 
Como variedades de contratos atípicos encontram-se aqueles denominados mistos e coligados, de fundamental importância para se compreender a multiplicidade de arranjos possíveis para a formação do contrato de EV.

Uma EV, como se viu, não é propriamente uma empresa no sentido jurídico, mas uma empresa no sentido puramente econômico, portanto um empreendimento. Um empreendimento heterogêneo na sua conformação, por conta da agregação e complementação de módulos, os quais correspondem às partes essenciais de empresas tradicionais.

Formar uma EV, para a engenharia, corresponde a concatenar do ponto de vista técnico todas as funções empresariais, agregando pessoas, processos e tecnologia a fim de prover o mercado de bens. Formar uma EV, do ponto de vista jurídico, significa estabelecer uma cadeia de obrigações e direitos que suportem sua objetividade econômica, levando em conta a natureza dos módulos que estão se agregando, os fluxos de informação, de bens e de serviços determinados pela engenharia.

Uma EV que se pretenda formar sem qualquer ajuste prévio, como no caso de um contrato de cluster, como o aqui proposto, dependeria de um arranjo bastante detalhado e pormenorizado para cada conexão e tipo de fluxo, o que corresponderia a uma multiplicidade de contratos, todos necessariamente enfeixados numa mesma perspectiva de negócio.

Em doutrina, essa modalidade de contrato pode tanto corresponder àquilo que se denomina Contrato Misto , que "resulta da combinação de elementos de diferentes contratos, formando nova espécie contratual não esquematizada na lei. Caracteriza-os a unidade de causa." (GOMES,1979, 118), como pode significar um Contrato Coligado, que todavia não se confundem. Da coligação de contratos não resulta contrato unitário, como no contrato misto. No entanto, dependendo do mecanismo da coligação, em muito se assemelhará ao contrato misto. 
A união de contrato apresenta-se, na classificação de ENNECCERUS ${ }^{7}$ apud GOMES (1979), sob três formas: a) união meramente externa; b) união com dependência; c) união alternativa.

A união externa é simplesmente instrumental. Sem que haja interdependência entre os contratos, as partes os reúnem no mesmo instrumento, concluindo-os simultaneamente. Nesse caso, não há propriamente coligação de contratos, pois não se completam nem se excluem.

A união com dependência é a figura que mais se aproxima do contrato misto. Os contratos coligados são queridos pelas partes contratantes como um todo. Um depende do outro de tal modo que cada qual isoladamente é desinteressante. Mas não se fundem. Conservam a individualidade própria, por isso se distinguindo dos contratos mistos.

A dependência pode ser recíproca ou não.

Na primeira forma, dois contratos completos, embora autônomos, condicionam-se, reciprocamente, em sua existência e validade. Cada qual é a causa do outro, formando uma unidade econômica. Enfim a intenção das partes é que um não exista sem o outro. A coligação dos contratos pode ser necessária ou voluntária. A coligação necessária, também chamada genética, é imposta pela lei, como a que existe entre o contrato de transporte aéreo e o de seguro do passageiro. Quando decorre da vontade dos interessados, como se verifica ordinariamente, diz-se voluntária. Visto que nessa união de contratos há reciprocidade, extingue-se, ao mesmo tempo, a dissolução de um implicando a do outro.

A união com dependência unilateral verifica-se quando não há reciprocidade. Um só dos contratos é que depende do outro. Tal coligação requer a subordinação de um contrato a outro, na sua existência e validade. Os contratos permanecem, no entanto, individualizados. É o que poderia ocorrer por exemplo num contrato de fornecimento firmado por uma EV, em que o fornecimento ficaria subordinado ao próprio contrato de EV.

\footnotetext{
${ }^{7}$ ENNECCERUS, in Tratado de Derecho Civil, Derecho de Obligaciones, Tomo II.
} 
A união de contratos configura-se, por fim, sob forma alternativa. Dois contratos são previstos para que subsista um ou o outro, realizada determinada condição. Um contrato exclui o outro, quando a condição se verifica. Embora unidos, não se completam, como na união com dependência.

Em qualquer das suas formas, a coligação de contratos não enseja as dificuldades que os contratos mistos provocam quanto ao direito aplicável, porque os contratos coligados não perdem a individualidade, aplicando-se-lhes o conjunto de regras próprias do tipo a que se ajustam. Na união formal ou instrumental, sem qualquer dificuldade, porque não há interdependência. Nos contratos interdependentes, o condicionamento de um ao outro não constitui obstáculo à aplicação das regras peculiares a cada qual. Na união alternativa, aplica-se o direito relativo ao contrato subsistente.

Em resumo, distinguem-se na estruturação e eficácia as figuras dos contratos coligados e dos contratos mistos. Naqueles há combinação de contratos completos. Nestes, de elementos contratuais, enquanto possível a fusão de um contrato completo com simples elemento de outro. Pluralidade de contratos, num caso; unidade, no outro.

A questão da pluralidade de contratos enseja um ambiente bastante confuso na hora de interpretá-los e julgá-los. O problema dos contratos mistos consiste fundamentalmente na determinação de sua disciplina jurídica. Não tendo regulamentação legal específica, é preciso saber que regras lhe são aplicáveis, além, naturalmente, dos princípios gerais do Direito Contratual. Três soluções dividem a preferência dos escritores: $1^{\mathrm{a}}$ ) a da combinação; $2^{\mathrm{a}}$ ) a da absorção; $3^{\mathrm{a}}$ ) a da aplicação analógica. 
A teoria da combinação parte de que é possível decompor e isolar os elementos de qualquer contrato atípico para lhe aplicar a respectiva disciplina legal. Em conseqüência, um contrato misto é disciplinado pela aplicação direta das regras atinentes a cada parte de que se compõe, combinadas entre si. Tais regras acompanham o elemento destacado e se unem aos elementos legais que regulam partes também dissociadas de outros contratos. Admite ele que entre o elemento legal e os efeitos jurídicos há um laço abstrato por força do qual estes se produzem sempre em função daquele.

Para a solução de conflitos no bojo de uma EV tal teoria é inaceitável, posto que o processo de decomposição, que preconiza, assenta no falso pressuposto de que o contrato é uma soma cujas parcelas podem ser isoladas. A verdade, porém, é que "os elementos de um contrato não são justapostos, mas, ao contrário, compenetrados e soldados uns aos outros em uma unidade orgânica (GOMES, 1979)”.

Segundo o mesmo autor, os partidários da teoria da absorção partem do pressuposto de que em todo contrato misto há um elemento preponderante ao qual se subordinam, todos os outros. O que se observa entretanto, nos verdadeiros contratos mistos a relação entre suas partes é de coordenação. Por outro lado, nem sempre tem paradigma legal o elemento tido como preponderante.

Só a teoria da aplicação analógica oferece critério aceitável para a disciplina jurídica dos contratos atípicos "stricto sensu" igualmente aplicável aos contratos mistos. "Consiste este critério na aplicação do processo analógico de interpretação. A tarefa do intérprete é procurar o contrato típico do qual mais se aproxima o contrato atípico para aplicar a este normas que disciplinam aquele; se esse recurso falha, por não haver contrato típico com o qual tenha o contrato atípico maior afinidade, emprega-se a analogia juris, invocando-se os princípios gerais de Direito Contratual" (GOMES, 1979).

O critério da aplicação analógica é, entretanto, insuficiente, porque com os subsídios na analogia não se obtém tutela jurídica idônea para todas as espécies contratuais inominadas. 
Essa discussão, porém, é indiferente quando uma EV entra em operação e as obrigações são regularmente cumpridas, em especial quando o mecanismo de arbitragem entra em funcionamento e suas decisões são implementadas regularmente. Não fosse a arbitragem, estariam as partes sujeitas, como já se assinalou noutra oportunidade, aos percalços de uma decisão judiciária distante da realidade dos negócios subjacentes e mergulhada numa miríade de alternativas doutrinárias.

Talvez a referência a um modelo legal ou jurisprudencial, tanto nos países do filo romano germânico quanto nos países da common law, advenha dessa perplexidade, desse susto com o novo, o não regulamentado.

O fenômeno da atipicidade dos contratos e sua qualificação como mistos não é novo, e no sistema brasileiro são identificáveis espécies que mutatis mutandi tem muito a ver com uma EV: o contrato de hospedagem; o de excursão turística; o de claque; o de equipe; o de exposição; o de embalagem; o de competição desportiva; o de guarda e limpeza de um veículo; o de publicidade; o de aluguel de cofre bancário. O contrato de hospedagem, por exemplo, embora usual, não está regulado especificamente, é contrato misto, que compreende elementos da locação de coisas, da locação de serviços, da venda e do depósito.

O Contrato de EV, guardadas as devidas proporções terá comportamento semelhante, ou seja, terá um objetivo central a ser alcançado, mediante a agregação de inúmeras obrigações assumidas pelos parceiros que, invariavelmente, estarão inseridas em categorias específicas de contratos, que podem inclusive nem ser típicos. Internamente à EV o que se pode afirmar é que em linhas gerais essas obrigações estarão orbitando entre contratos de prestação de serviços (locação de serviços), empréstimo de bens (locação, comodato), financiamento (mútuo), fornecimento de know-how (licenciamento de patente, engineering), porém todas amalgamadas num empreendimento comum. Do ponto de vista externo, as relações assumem feição nitidamente comercial, quando se tratar de fornecimento de bens, ou pode ainda ser caracterizada como civil se o seu objeto consiste na prestação de serviços e 
forem estes reputados pela legislação como civis. Existe ainda a possibilidade de que esse contrato nasça coligado com o próprio contrato de $\mathrm{EV}$, o que é bastante plausível na medida em que mais do que produtos uma EV busca soluções, e geralmente customizadas, com participação ativa do cliente. Nessa hipótese então, o contrato deverá ser mais sofisticado em termos de redação, com acréscimo de cláusulas que atribuam responsabilidades ao cliente e preferencialmente submetam eventual conflito à arbitragem, se não a da OV pelo menos qualquer outra.

Fora essa hipótese, em que a EV se coliga externamente, na medida em que já se dispõe de ferramentas adequadas para o desenvolvimento das relações entre os parceiros, o ideal é que o plano de negócios discutido e aprovado à unanimidade se erija no contrato de $\mathrm{EV}$, desde a sua fase de criação conforme descrito em tópico anterior. O plano de negócios assim ajustado, assumirá todas as vezes de um contrato, será então o contrato de $E V$, cuja linguagem será acessível àqueles operadores técnicos que administrarão o fluxo de informações, trazendo consigo todo o conteúdo obrigacional estipulado no contrato de cluster ou contrato de $\mathrm{OV}$.

A tabela 1 abaixo resume essas modalidades contratuais ocorrentes tanto no nível da OV quanto da EV.

Tabela 1 - Quadro Resumo De Contratos

\begin{tabular}{|l|l|l|}
\hline CONTRATOS & INTERNOS & EXTERNOS \\
\hline OV & Contrato de Cluster & Apenas eventualmente e sem fins lucrativos \\
\hline EV & Comodato; & Compra e venda; \\
& Locação; & Licenciamento de marcas e \\
patentes; & Engineering; & Prestação de serviços \\
& Mútuo; \\
& Leasing; \\
& Transferência de Know-How \\
& Etc. & \\
\hline
\end{tabular}




\subsubsection{As EVs e o Direito Anti-truste}

Muito embora se tenha difundido a idéia de que a legislação anti-truste possa constituir uma importante barreira para o desenvolvimento da concorrência dinâmica, conforme reconhecem GOLDAMAN et al. (1995), afortunadamente para o caso brasileiro a questão assume um contorno diferente.

Em verdade existem dois sistemas de defesa da concorrência, de um lado o que proíbe restrições à concorrência pelos danos potenciais que produzem e, de outro, o que as reprime somente pelos danos efetivamente produzidos. De acordo com COELHO (1998), a tendência do primeiro é a de tomar a concorrência como um fim em si mesmo (teoria da concorrênciacondição). A do segundo sistema é a de considerar a concorrência como apenas um dos diversos bens da estrutura do livre mercado dignos de tutela (teoria da concorrência-meio). Nesse último caso, a repressão aos acordos, oligopólios, domínio de mercado ou concentração de empresas está condicionado ao efetivo prejuízo ao interesse geral.

O direito norte-americano é um dos exemplos do primeiro sistema, em que a concorrência é uma condição, um fim em si mesmo. Disso resultando numa exacerbada repressão tão somente pelo dano potencial que acordos e arranjos empresariais possam causar. 
Evidentemente, uma EV em princípio não representaria nenhuma das formas conhecidas de prática anti-concorrencial, porém, no limite, havendo a participação de um número grande de concorrentes de um mesmo setor numa mesma parceria, à luz da legislação americana o empreendimento poderia ser obstruído pelo Estado. No caso brasileiro, bem como no da União Européia, a legislação filia-se ao sistema da concorrênciameio, onde tem relevo a melhoria da produção ou distribuição, o progresso técnico e econômico, os benefícios aos consumidores e a necessidade ou desnecessidade de restrição relacionados com a conduta empresarial investigada, segundo BUKHARDT ${ }^{8}$ apud COELHO (1998).

No nosso caso portanto, é do cotejo entre vantagens e desvantagens advindas dos acordos empresariais que o Estado vai identificar a necessidade de aplicação de sanções. Não há defesa da competição como valor abstrato, em detrimento de melhorias dos níveis de emprego, desenvolvimento tecnológico, melhor atendimento aos consumidores etc. Essa missão discricionária foi confiada ao CADE - Conselho Administrativo de Defesa Econômica, com apoio do SDE - Secretaria de Direito Econômico do Ministério da Justiça. Embora tenha sido criado em 1962 através da Lei 4.137, como órgão da administração direta federal, sofreu sensível reformulação através da Lei 8.884/94, transformando-se em autarquia, com poder judicante em todo o território nacional $\left(\operatorname{art.} 3^{\circ}\right.$ ). Suas decisões são desprovidas de caráter judiciário, o que equivale dizer de natureza meramente administrativa, passível de revisão pelo Poder Judiciário.

É forçoso reconhecer, portanto, que não existem embargos à formação de EVs em suas inumeráveis formas e dimensões, desde que concretamente não impliquem em danos efetivos à concorrência. Não seria demais relembrar, que as EVs, por definição são efêmeras e voltadas às oportunidades únicas, e talvez se dissolvam antes mesmo de virem a constituir objeto de análise pelo CADE, ou de serem notadas por eventuais lesados.

${ }^{8}$ JÜRGEN BUKHARDT. Kartellrecht. München, C. H.Beck, 1995 


\subsubsection{O Comércio e Eletrônico e a Lei Uniforme Uncitral}

O comércio eletrônico tem despertado não apenas interesse mas principalmente dúvidas, notadamente no campo jurídico, cujas respostas podem significar importante avanço no sentido da realização plena das Empresas Virtuais, em termos de segurança e agilidade.

A tecnologia de informação é simplesmente um novo meio de se realizar uma das mais antigas atividades do homem: o comércio. Partindo-se de diversas definições de comércio é possível extrair um conceito simples para Comércio Eletrônico, qual seja a operação que consiste em comprar e vender mercadoria ou prestar serviços por meio eletrônico.

O principal meio através do qual o comércio eletrônico se torna uma realidade é, sem sombra de dúvida, a Internet. No Brasil, a Internet surgiu comercialmente em 1995, ano em que o Ministério das Comunicações publicou a Norma n. ${ }^{\circ}$, que regula o uso de meios de rede pública de telecomunicações para o provimento e utilização de serviços de conexão à Internet.

Trata-se, portanto, de atividade bastante recente. Mais recente que o Código de Defesa do Consumidor e bem mais atual que o Código Comercial.

Para a Norma n. ${ }^{\circ}$ 4/95, Internet é o "nome genérico que designa o conjunto de redes, ou meios de transmissão e comutação, roteadores, equipamentos e protocolos necessários à comunicação entre computadores, bem como o software e os dados contidos nestes computadores". Parece evidente que a Internet nada mais é que um meio de comunicação, assim como o telefone e o fax.

Em se tratando simplesmente de um meio, há os que apregoam que a Internet não traz qualquer inovação no campo jurídico. 
Ela seria apenas uma forma nova de se fazer as mesmas coisas que já se fazia antes dela. Por exemplo, caluniar em um jornal ou na televisão seria o mesmo que caluniar na Internet. Outras situações entretanto não são tão claras assim, como no caso do crime de invasão de domicílio. Como em direito penal não é válida a incriminação por analogia, invadir um sistema por ora não seria o mesmo que invadir uma casa.

Também não estão claros ainda os mecanismos através dos quais o consumidor obterá a devida reparação quando for lesado. No Brasil há a inversão do ônus da prova, ou seja, o fornecedor é que deverá provar que não agiu com culpa, ou que houve culpa exclusiva do consumidor; mas e se a compra for de caráter internacional, haverá conflito entre sistemas. Além disso, nos casos em que não se configure uma relação de consumo, a flexibilidade dos meios de prova não é o mesmo, valendo ainda o vetusto $\mathrm{CCo}$ (Código Comercial).

Além da invasão de sistemas, o que mais preocupa é a destruição de dados de computador. Que seguiria a mesma sorte do crime de invasão, ou seja, se a conduta não é tipificada expressamente não pode haver incriminação. Sabe-se que o dano é a destruição dolosa de coisa alheia móvel ou imóvel, faltaria portanto a inclusão dos dados de computador no rol das coisas, estampado o CC. O § 3o do art. 155 do Código Penal (Furto), equipara à coisa móvel a energia elétrica ou qualquer outra que tenha valor econômico, talvez fosse o caso de se criar um outro parágrafo equiparando à coisa móvel informações contidas em computador.

Poder-se-ia cogitar da cobrança de tributos pela utilização da Internet, afinal a Internet é uma via pela qual se realizam atividades comerciais, nesse sentido a instituição de um pedágio eletrônico não está longe de significar alternativas concretas para orçamentos públicos combalidos. A tributação de compra e venda de bens e serviços totalmente realizada pela Internet, já constitui objeto concreto de preocupação do legislador brasileiro e internacional. 
Note-se que por ora há muito mais perplexidades que respostas concretas, cabendo ao Estado, pois, dentre outras ações de caráter geral, i) informar, educando e oferecendo uma infra-estrutura moderna e compatível com as melhores tecnologias; ii) coibir os abusos e o mau uso da rede; iii) informar com ampla divulgação quais são as regras que norteiam a utilização da rede.

Pelo fato de ser o comércio eletrônico algo ainda novo para a maioria dos brasileiros e até mesmo desconhecida para muitos, e por não ter havido ainda grandes problemas jurídicos na utilização da rede mundial, não existe no Brasil nenhuma lei a respeito do assunto. Para que não se diga que não há nenhuma regulamentação, o que existe, além da já referida Norma no 4/95 são as Resoluções N..$^{\circ} 1$ e N.o 2/98 do Comitê Gestor Internet do Brasil, vinculado à Secretaria de Política de Informática e Automação do Ministério da Ciência e Tecnologia.

Estas Resoluções tratam apenas de regras de registro de nome de domínio, delegando competência para registrar e fiscalizar o uso dos referidos domínios à Fundação de Amparo à Pesquisa do Estado de São Paulo (FAPESP), que cobra valores compatíveis com os vigentes internacionalmente.

A comunicação virtual, o avanço da tecnologia da informação e a abertura das redes são fatores que impulsionaram muitos países à criação de normas jurídicas que estabelecem regras, proporcionando a integração da tecnologia à realidade social de cada comunidade. Muitos países da União Européia, por exemplo, estão iniciando sua atividade legislativa no âmbito do comércio eletrônico, o que traz à U.E.(União Européia) a preocupação de harmonizar as regras. A situação atual das atividades legislativas, no campo do comércio eletrônico, em vários Estados-membros da Comunidade Européia, tais como Áustria, Dinamarca, Finlândia e Reino Unido não é muito diferente da situação brasileira, haja vista estarem todos aqueles países ainda na fase de projeto de lei.

No Brasil ainda não há um projeto de lei, mas já existem estudos de anteprojetos de lei, na maioria baseados na Lei Modelo da UNCITRAL. 
A UNCITRAL (United Nations Commission on International Trade Law), comissão especial da ONU (Organização das Nações Unidas) que trata de legislação comercial internacional, elaborou e tem divulgado uma lei modelo de comércio eletrônico, que tem sido um ponto de partida para a legislação de muitos países. Esta lei seria aplicável a todo tipo de informação em forma de mensagem de dados utilizada no contexto de atividades comerciais. Ela tem um caráter internacional e visa promover a uniformidade de sua aplicação e a observância da boa-fé.

Dentre as diversas sugestões apresentadas por este modelo de lei, destacam-se as seguintes:

a) Art. 5o Trata do reconhecimento jurídico dos contratos eletrônicos. Prevê que não se negará validade ou força obrigatória a um contrato pela única razão de haver sido celebrado por meio eletrônico.

b) Art. $6^{\circ}$ Aborda a forma escrita dos contratos eletrônicos. Estabelece que quando a lei exigir que um negócio seja celebrado por escrito, este requisito será satisfeito eletronicamente, desde que as informações permaneçam disponíveis e acessíveis, para uma consulta posterior.

c) Art. $7^{\circ}$ Cuida da assinatura dos contratos eletrônicos. Prescreve que nos casos em que forem exigidas as assinaturas das partes contratantes nos instrumentos contratuais, este requisito poderá ser dispensado se:

i) for utilizado um método eficaz de identificação das partes contratantes;

ii) este método for suficientemente confiável e apropriado para as finalidades do negócio

jurídico.

d) Art. 11. Versa sobre a formação dos contratos eletrônicos. Prevê que se as partes não convencionarem de maneira diversa, a oferta e aceitação poderão ser expressas eletronicamente. 
e) Art. 15. Regula o tempo e lugar de envio e recepção de uma mensagem eletrônica. Determina que se as partes não convencionarem de maneira diversa, a mensagem será considerada enviada quando ela entra em um sistema de informação fora do controle do emissor e recebida nos seguintes casos: se o destinatário designou um sistema de informação para receber mensagens eletrônicas, a recepção acontecerá:

i) no momento em que a mensagem entrar no sistema designado;

ii) ou no momento em que a mensagem for recuperada pelo destinatário, quando esta entrar noutro sistema que não o designado. Se o destinatário não designou um sistema de informação, a recepção acontecerá no momento de entrada da mensagem no sistema de informação do destinatário.

Não é tarefa difícil concluir que o Brasil também necessita de uma legislação moderna que defina, por exemplo, critérios de utilização e autenticação de assinaturas eletrônicas, um tratamento aduaneiro totalmente novo, regras claras sobre tributação (v.g. aplicação de ISS ou ICMS), etc.

Seja qual for a legislação estabelecida no Brasil, ela deverá partir de alguns princípios fundamentais, dentre os quais destacam-se a segurança nas transações e a garantia de privacidade na troca de informações privadas, sem os quais não teremos um comércio eletrônico eficaz e confiável.

Nesse sentido, em se tratando de transações efetuadas via Internet, os requisitos de segurança são:

? ? Autenticação de usuários. O termo autenticação refere-se ao reconhecimento por ambas as partes de que um participante é de fato quem ele diz ser. A autenticação deve preferencialmente ser feita de ambas as partes, ou seja, se A e B trocam dados, A deve certificar-se que B é realmente B (e não C fazendo-se passar por B), e viceversa. 
? ? Privacidade dos dados em trânsito. Deve-se garantir que ninguém possa conhecer o conteúdo dos dados transmitidos, a não ser os envolvidos na transação. Também designada por confidencialidade da transmissão.

? ? Integridade da informação trocada. Além da garantia da confidencialidade dos dados, em algumas aplicações a certeza de que os dados estão íntegros (nenhuma informação foi retirada, adicionada ou modificada durante sua transmissão) pode ser ainda mais importante. Imagine por exemplo uma transação onde um corretor de ações confirma uma compra via Internet em um pregão eletrônico: neste caso a integridade da informação — quais ações e em que quantidade comprar — é muito mais importante que mantê-la em caráter confidencial.

? ? Garantir autoria. Autoria refere-se, como o próprio nome diz, à garantia sobre quem é o verdadeiro autor da informação ou documento transmitido.

? ? Controle de acesso - quem pode fazer o quê, onde e quando. Trata-se de um dos requisitos mais básicos de segurança, sendo aplicado não só em redes abertas como a Internet mas também em redes fechadas, como as corporativas, e mesmo em aplicações stand-alone tal controle pode ser pertinente. Não é recomendável que todos os funcionários de uma empresa tenham acesso à sua folha de pagamentos, por exemplo.

? ? Garantir escopo. O escopo de uma informação diz respeito ao seu destino final, não em termos do usuário receptor mas da transação em si. Por exemplo, informações sobre o fluxo de caixa da empresa têm um escopo financeiro, e não devem ser disponíveis para funcionários que não sejam da área financeira, ou possivelmente da alta administração. 
? ? Realizar auditorias. Uma das principais formas de assegurar que as necessidades e políticas de segurança estão sendo cumpridas é através de auditorias internas. Portanto, todo sistema que envolve dados seguros deve possibilitar a realização de auditorias sobre o manuseio destes dados: quem e quando acessou, modificou, transmitiu, apagou etc.

As perplexidades trazidas pela INTERNET ao mundo do direito são de longe superadas pelas vantagens que as comunicações pelo meio eletrônico oferecem, especialmente tendo em conta as iminentes reformas na legislação e os mecanismos de segurança em franco desenvolvimento, de forma a impactar favoravelmente o paradígma virtual. Sem sombra de dúvida a ocorrência das EVs dependem muito mais de oportunidades efetivas de negócios do que propriamente da superação de embaraços de natureza legal ou tecnológico.

Diante de todo o exposto confirma-se a possibilidade de surgimento de EVs sem qualquer reforma profunda na legislação. Os principais mecanismos que viabilizam as EVs foram identificados, e com base na exclusão de arquétipos legais inadequados bem como na articulação de regras próprias do direito contratual, como a condição susupensiva, o précontrato, a arbitragem e a distribuição da responsabilidade solidária, chega-se ao entendimento de que uma aplicação prática depende em primeiro lugar da constituição de uma OV, que pode se dar em torno de um contrato com os moldes de um associação civil, podendo nem mesmo necessitar de registro a fim de criar-se uma nova pessoa jurídica , distinta da dos membros. Em segundo lugar, a partir da existência de uma rede estável, é que se delineia o cenário futuro, que, de forma latente funciona como um segundo estágio a ser deflagrado, para entrar em operação ante uma oportunidade efetiva de negócio. É nesse e momento então, que cada membro instado a cooperar, põe suas competências essenciais em contato com as dos demais membros. 
Através de uma multiplicidade de contratos típicos, as competências são postas em conexão, formando então uma unidade de negócio em torno de um escopo único. Uma vez que o peso formal dos contratos foi previamente ajustado no nível da OV, torna-se possível atribuir a mesma eficácia, e sem maiores rigores formais, ao plano de negócio, podendo sua base documental ser meramente eletrônica, desde que observados todos os itens de segurança acima listados.

Com essa perspectiva e buscando confirmação prática de que a solução encontrada é que o presente trabalho se inseriu de forma definitiva no projeto VIRTEC, tratado no capítulo seguinte. 


\section{Aplicação da infra-estrutura proposta à uma Organizaçào Virtual em formação - VIRTEC}

\subsection{Um Cluster induzido}

Para o caso específico do projeto desenvolvido no âmbito do NUMA, que foi denominado VIRTEC, algumas adaptações ao modelo proposto foram indispensáveis, sem contudo ter havido comprometimento de suas características fundamentais. Muito embora na definição de PORTER (1999) o cluster seja um grupamento de industrias situadas na mesma região, que vai se formando espontaneamente pelas trocas constantes que realizam, sem verticalização, sem criação e manutenção de associações, no caso específico da VIRTEC, optou-se por intensificar a existência ainda que latente de um cluster, promover a aproximação das empresas, formar uma cultura de relacionamento, e a partir daí atribuir a ele, ferramentas para que se erija em condição de OV.

Nesse sentido, houve a criação de uma equipe de pesquisa de campo que estabeleceu como pressupostos a existência de empresas na região de São Carlos, que tivessem uma relação de complementaridade, que tivessem alguma competência essencial de nível internacional e que já se utilizassem de modernas práticas administrativas, afeiçoadas ao trabalho em equipe.

O resultado desse levantamento foi a identificação de 9 (nove) empresas ligadas aos setores metal-mecânico, polímeros que tinham o seguinte almejado. A partir da identificação foi realizada uma conferência com a participação de vários especialistas envolvidos com o tema e que de alguma forma estavam participando de projetos importantes no México, Estados Unidos, Inglaterra, Suíça e Alemanha. 
O objetivo era disseminar em nível regional a idéia, e durante os seminários abordar aquelas empresas que haviam sido alvo do levantamento.

Dessa estratégia resultou o engajamento das 9 empresas que passaram a freqüentar reuniões, ligadas em princípio apenas por uma agenda de eventos e visitas recíprocas.

\section{As dificuldades de implementação do informalismo}

Nem todas a empresas estão afeiçoadas a um relacionamento calcado puramente na confiança, seja por seu próprio histórico no relacionamento mercantil em geral, seja pela percepção de que o ambiente dos negócios no Brasil não o recomenda.

De fato, logo no início das reuniões as principais queixas dos membros industriais estavam todas relacionadas à proteção de suas informações, uma vez que seria indispensável um levantamento pormenorizado da planta industrial, processos, mercados, etc. O temor nem era tanto com relação aos membros acadêmicos envolvidos nesse levantamento, mas principalmente com relação aos demais empresários.

De início já houve sugestões de elaboração de atas para todas as reuniões e uma recusa expressa em aceitar ajustes de natureza verbal. Um contrato escrito afigurava-se imperioso.

Com o passar do tempo, o convívio acabou gerando uma maior tranqüilidade, e na medida em que a VIRTEC passou a ganhar visibilidade na mídia, os membros industrias passaram a enxergar as inúmeras possibilidades de crescimento. Com a realização de um Benchmarking em todas as empresas, o conhecimento recíproco das potencialidades por si só acabou determinando parcerias isoladas. 
Mesmo assim, um contrato escrito era uma exigência geral. Por conta dessa pressão, foi oferecida uma minuta contemplando o esquema básico esposado neste trabalho, para que fosse discutida e aprovada. Curiosamente, após aprovação unânime, o documento ainda não se encontra formalmente assinado, mas os membros continuam participando do projeto, contribuindo financeiramente e compartilhando de um banco de dados. Contrataram estagiários ligados ao NUMA, para trabalharem dentro de suas empresas e servirem de elo uns com os outros.

\subsection{O elo com a Universidade}

O conceito cluster não excluí a participação de agências públicas e outras modalidades de provedores de infra-estrutura, e dadas as peculiaridades da VIRTEC, de iniciativa total do NUMA, que afinal representou o induzimento referido no item anterior, sua participação acabou ocupando um papel central.

Se de um lado a participação intensa da universidade através de professores e alunos significa garantia para os empreendedores que estavam se aproximando, por outro lado, a participação da Universidade no projeto, sem contudo ferir os limites legais impostos à autarquia, nem mesmo desfigurar o informalismo que deveria ser a tônica dessa parceria, significava a garantia de acesso às informações e principalmente o monitoramento da aplicação prática do modelo teórico.

A forma encontrada para atender as expectativas de ambos os lados, dada a neutralidade que significa uma associação civil, destinada especificamente para fins científicos, foi a participação aberta, como associados, de professores e alunos. Foram criadas, então, duas categorias de membros, com diferentes responsabilidades, direitos e prerrogativas: os membros industriais e os membros acadêmicos. 
Por essa e outras razões, optou-se pelo desenho do contrato sem necessidade de personificação, afastando toda sorte de empecilhos de natureza cartorária e fiscal. Assim, ao invés de estatuto de uma associação civil, optou-se por denominá-lo simplesmente contrato de cluster, com relevo e importância apenas para seus membros, indiferente ao Estado e ao mercado, pelo menos enquanto as obrigações dos membros estiverem sendo regularmente cumpridas.

Em acréscimo a esta vinculação contratual com o meio acadêmico, deliberou-se em assembléia, a apresentação de uma relação de estagiários com o perfil previamente definido pelos membros, a serem por estes últimos contratados e promoverem o estreitamento de relações. Com parte do seu tempo dedicado exclusivamente à VIRTEC, os estagiários já tem proporcionado uma maior agilidade na troca de informações sobre recursos e processos.

A importância de se ter uma percepção clara dos processos e recursos como competências se coloca no fato de que isso garante às Empresas Virtuais a flexibilidade que necessitam para operar. Uma vez que os parceiros consigam ver seus recursos e processos de negócios como competências passíveis de integração, produtos com alto grau de diferenciação podem ser originados e oferecidos ao mercado, ao invés de se aguardar passivamente uma demanda especial.

\subsection{Identificação de competências e desenvolvimento de produtos}

Conquanto se pudesse argumentar no sentido da existência de uma certa barreira em função de provirem as empresas de diferentes segmentos da indústria, um importante passo foi dado a fim de melhorar a visualização mútua das competências entre os membros da OV. A identificação das competências das empresas demandou não apenas o levantamento, mas o agrupamento e a exposição das principais competências. 
Como resultado de discussões em reuniões internas e juntamente com os membros de indústria foi detectado que um dos maiores obstáculos era de como colocar a idéia de integrar diferentes competências de maneira efetiva. Isso se deveu principalmente ao fato de que os membros tinham um vago conhecimento mútuo como empresas, ou seja, não conheciam a fundo as competências uns dos outros.

A solução adotada foi mapear as competências como o auxílio de uma matriz. Foi montada uma matriz quadrada nove por nove $(9 \times 9)$ contendo todos as empresas-membro do cluster. As células correspondentes foram subdivididas em produtos, processos e tecnologias, a fim de não restringir o mapeamento, colocando tantas competências quanto possível. Nela, definiu-se os primeiros possíveis produtos virtuais entre elas, divididos nas categorias de relações já existentes e futuras. A matriz completa foi apresentada para nova análise na reunião seguinte e um produto virtual que incluísse o maior número de membros foi selecionado: uma cadeira de rodas acionada eletronicamente.

Com relação ao produto Cadeira de rodas, várias reuniões, a parti de abril de 1999, foram iniciadas com as empresas que fariam parte desta EV. Estas reuniões iniciaram com o estabelecimento do cronograma de atividades do desenvolvimento do produto e plano de negócios, que já passaria a valer como o contrato de EV. Algumas alternativas de desenharam, como por exemplo partir de uma cadeira nacional já pronta e apenas desenvolver um Kit para motorizá-la, ou seja, trabalhar sobre um produto já existente para fosse aperfeiçoado, ao invés de partir-se da estaca zero. Uma das empresas a assumiu o papel de empresa líder incumbindo-se do desenvolvimento e produção, enquanto as demais agregariam suas competências como fornecedores de serviços e peças. 
Apesar da matriz de competências, como ferramenta, ter representado um papel fundamental no agrupamento de competências das empresas do cluster, que também é identificado pela sigla GVI(Grupo Virtual de Industrias), à medida que a forma de cooperação for se tornando mais sofisticada, envolvendo mais de duas empresas - às vezes até parceiros externos à $\mathrm{OV}$ - a visualização de competências por meio da matriz tende a ser prejudicada. Afinal, crescerá excessivamente o número de variáveis e condições envolvidas. Da mesma forma, a matriz não é um sistema de informação que especificamente lida e seleciona competências.

Portanto, a fim de suportar processos de tomada de decisão em casos como este, a melhor abordagem para gerenciamento de competências foi o uso de um sistema de informação, denominado VISHOF (Virtual. Shop Floor), baseado numa arquitetura INTERNET, cujo papel é armazenar, gerenciar e compartilhar informações sobre recursos de chão de fábrica de uma determinada região. Este sistema de informações foi, inicialmente, proposto pelo projeto para ser implementado entre as empresas membro.

Foi feito, a partir de abril de 1999, um levantamento de recursos de chão de fábrica das empresas membro da VIRTEC, como parte do mecanismo para se identificar competências essenciais das empresas, e alimentar o sistema. As informações levantadas foram inseridas no sistema (banco de dados da VIRTEC). Os demais componentes (produtos, processos de negócios, tecnologias e habilidades) acabaram sendo levantados recentemente, em março de 2000, a partir de quando o sistema passou a operar efetivamente.

É importante frisar que, apesar da expansão do sistema VISHOF, a matriz de competências não perdeu seu valor. Porque uma problema crucial a ser resolvido é não apenas fornecer meios de integração e suporte de compartilhamento à informação, mas meios de entendimento de como o processo de empreendimento virtual ocorre. Este é o papel da matriz, dada sua simplicidade e transparência. Uma vez que os membros da OV entendam como estes processos ocorrem, serão capazes de vender informações sobre suas competências e agenciadores mais eficientemente. 


\subsection{O contrato proposto}

O contrato para a formação do cluster, que o transforma também em $\mathrm{OV}$, já foi concebido em suas linhas gerais, já foi discutido por todos os membros foi aprovado, restando apenas as assinaturas, muito embora já se encontre em vigor, de acordo com as regras do nosso sistema jurídico.

Naquele instrumento foram estipulados os princípios fundamentais, os mecanismos de ingresso e saída de parceiros, as regras para funcionamento das EVs, com base no pacto de contrahendo, a fixação da responsabilidade solidária, tudo isso com redação jurídica apropriada através de um corpo articulado de dispositivos. A minuta do instrumento documento encontra-se no Anexo . 


\section{Conclusões}

Uma das primeiras e mais importantes conclusões refere-se à possibilidade de realização plena de Organizações Virtuais e Empresas Virtuais no atual quadro legal brasileiro, a despeito da ausência de regulamentação específica, sem qualquer prejuízo das características conceituais mais importantes, ressalvando-se porém, que a confiança, descrita como atributo não pode ser havida como infra-estrutura legal, razão pela qual um esquema contratual é oferecido como alternativa.

As Organizações Virtuais, enquanto plataformas ou redes estáveis, sem trocas comerciais com o meio externo, encontram nos contratos de natureza civil ambiente adequado para sua consolidação, podendo, conforme o tipo de relacionamento e a natureza do agente externo, adquirir personificação. Ou seja, se além do propósito de estreitamento de vínculos de conhecimento recíproco e confiança para a formação de EV no momento oportuno, se dispuser a OV a captar recursos financeiros adquirir bens etc., ou prestar serviços diretamente a terceiros - serviços esses reputados civis, sua adaptação aos requisitos legais e subsequentes registro e inscrição serão simples mas imperativos. Mesmo nessa hipótese, em que pese o acréscimo de algum custo financeiro e de algum desconforto burocrático, não haverá comprometimento algum de seus elementos caracterizadores, uma vez que seu propósito é ser perene.

No que tange ainda às $\mathrm{OV}$, não existem mudanças significativas a serem implementadas na legislação que venham a satisfazer interesses maiores tanto do Estado quanto dos particulares, ou até mesmo do meio acadêmico, sendo válido afirmar que o perfeito funcionamento de uma OV depende mais da qualidade dos parceiros envolvidos e do fiel cumprimento das regras que livremente estipularam, do que da qualidade de um modelo fixado na lei. 
A colaboração de uma reforma legislativa se resumiria a um papel secundário, periférico, assim como ocorreu com a recente reforma introduzida pela Lei 9790/99, que de fato agregou uma nova perspectiva para as OV no Brasil, que poderão usufruir de novos direitos e gozar de determinados benefícios, caso elas se personifiquem e preencham os novos requisitos fixados na referida norma. Com efeito, preenchidos tais requisitos, as pessoas jurídicas sem fins lucrativos, dentre as quais se insere a associação civil, passam a ser qualificadas como "Organizações da Sociedade Civil de Interesse Público". Para ostentar essa qualificação deve a entidade exercer direta ou indiretamente projetos com as seguintes finalidades, dentre várias outras: experimentação, não lucrativa, de novos modelos sócio-produtivos e de sistemas alternativos de produção, comércio, emprego e crédito; estudos e pesquisas, desenvolvimento de tecnologias alternativas, produção e divulgação de informações e conhecimentos técnicos e científicos que digam respeito às várias atividades mencionadas pela lei. Uma vez reconhecida pelo Estado e atribuída tal qualificação, abre-se a possibilidade de estipularem com o Poder Público instrumentos contratuais de parceria para execução de atividades de interesse público, de receber subvenções, de gozar de isenções fiscais etc.

É inegável o aproveitamento que se pode tirar dessa inovação, mas como já assinalado, nenhum acréscimo ou supressão de direitos essenciais à formação de uma OV ocorreu, nem mesmo de natureza taxonômica. É muito mais provável, caso essa modalidade de cooperação vingue em solo brasileiro, que o Estado crie algum tipo de regulamentação no sentido de ampliar a esfera de proteção ao consumidor e ao crédito. Que em qualquer caso levaria tempo. 
Pelas peculiaridades da nossa legislação, bem como do sistema jurídico ao qual está filiada, a montagem de uma OV nos termos como aqui propostos, resolve de forma integral sua demanda de estrutura e garante ainda que parcialmente a estruturação das EV. Disso resultando poder-se afirmar que a OV desenhada neste trabalho é própria infra-estrutura da EV. Fazendo um analogia com o jargão da informática, a OV está para o hardware como a EV está para o software.

Como a OV em princípio é indiferente ao mercado, ou seja, não realiza com ele trocas de natureza formal comercial, e seu propósito básico é predispor seus membros a cooperarem quando oportuno, com relação ao meio externo ela é algo fixo e latente. No momento da formação das EVs apenas, é que o sistema se abre para o meio externo, e apenas uma ou algumas das unidades empresariais envolvidas e que se farão notar por consumidores e fornecedores.

Uma vez criadas as condições para a cooperação, pela consolidação de uma OV, a formação, desenvolvimento e dissolução de uma EV já se encontram parcialmente estruturados por força daqueles mecanismos que foram descritos como pré contrato e condição. Resulta daí que nas trocas internas, entendidas aqui as mobilizações de ativos físicos, recursos humanos e know-how, tudo poderá se processar com base em contratos completamente informais, entabulados e documentados exclusivamente em meio eletrônico, se for o caso. De outro lado, nas trocas externas, uma ou mais empresas se apresentariam para figurar como parte em alguma relação contratual típica de fornecimento de bens ou prestação de serviços, repassando riscos, custos e lucros, com base no que foi estipulado nos próprios estatutos da $\mathrm{OV}$ e nos arranjos internos específicos para aquela oportunidade.

Sobre esse último aspecto poderiam incidir melhorias importantes advindas de uma reforma na legislativa, ou seja, reconhecendo a legislação a existência do fenômeno. Com efeito, pelo fato de assumir uma EV relações com o meio externo, ainda que com a fachada da denominada "empresa líder", adquire especial relevância para os vários ramos do Direito Público, tais como o Tributário, o Trabalhista, o do Consumidor, o Internacional etc. 
Muito embora já se tenha afirmado noutro tópico que os meios de prova e os mecanismos de contratação para o Direito Comercial tenham sido concebidos de modo mais flexível, cabe lembrar que aquelas concepções são muito antigas, datando de época em que sequer era imaginável o meio eletrônico. Nesse sentido, os esforços da comunidade internacional para disciplinar a matéria, através das normas da UNCITRAL resultarão num grande proveito para os empreendimentos virtuais.

Outra conclusão importante é que a opção de participação numa OV ou EV, dentro das premissas aqui fincadas, impõe uma troca de responsabilidades entre a alta administração e os níveis inferiores dentro da própria organização partícipe, tendo em vista o fato de que justamente nesses níveis é que haverá a conexão com as demais organizações, sendo certo que o operador das informações será o executor do contrato. Se numa organização tradicional ter informações é sinônimo de poder, nas OV/EV, o poder é resultante da capacidade de compartilhar informações entre empresas cooperantes.

Por tais características, impactantes na horizontalização dos organogramas, pode-se afirmar com pouca margem de erro, que as empresas de pequeno e médio porte são as que mais podem colher benefícios desse tipo de empreendimento, desde que, obviamente, apresentem aquele perfil esperado, ou seja, ter alguma excelência a ser somada e compartilhada.

A excelência, por outro lado, tende a ser cada vez mais um atributo das pessoas, posto que administram informações de conteúdo tecnológico, sobre operação de equipamentos e controle de processos. No esquema de parcerias virtuais, vislumbra-se a possibilidade de um reencontro do trabalhador intelectual com a atividade empresarial, como se uma unidade de negócios fosse. Diferentemente do empregado contratado, que basicamente recebe salários por um trabalho subordinado, com participação simbólica nos lucros, sem qualquer risco; ou do trabalhador avulso terceirizado, que trabalha isoladamente por uma empreitada específica, a pessoa física ligada a uma EV, encontra-se na condição sócio, agregando sua competência e participando dos riscos bem como dos lucros na proporção de sua contribuição. 
Do ponto de vista da aplicação prática, o que se pode concluir em síntese até o presente momento é que a idéia de OV além de plenamente realizável, encontrou na VIRTEC excelente ambiente para implementação. Embora não se disponha de nenhuma parceria envolvendo a totalidade dos seus membros, ainda que parcialmente a EV já se tornou realidade, tendo em vista a fabricação de alguns produtos. A implementação da infraestrutura legal de uma OV em São Carlos, a partir do induzimento de um cluster, até então latente, permitiu verificar os limites da teoria, testar o aparato legal e medir o grau de aceitação dos empreendedores. Nesse sentido, a experiência propiciada pela VIRTEC foi decisiva para o desenvolvimento do presente trabalho, facilitando a visualização do objeto, direcionando as pesquisas e principalmente permitindo tirar ilações amparadas na realidade.

Cabe ainda esclarecer que o papel desempenhado pelo Direito neste trabalho, embora tenha ocupado boa parte da argumentação com seu método próprio, essencialmente dedutivo e episodicamente indutivo, não foi um papel central. A contribuição almejada neste trabalho não se situa no Direito, mas nele tem sua origem. Nenhuma discussão jurídica foi travada no sentido de agregar novas idéias o reler velhos axiomas. Algumas partes do Direito aqui referenciadas foram operadas como conhecimento científico registrado, de acesso a qualquer área do conhecimento científico, sem discussões de filigranas. O problema pode ser de interface, mas o enfoque é de Engenharia, na medida em que sua solução implica num aproveitamento tecnológico. Ou seja, o Direito operou como elemento de estoque e a Engenharia como elemento de transformação, tendo como resultante um modelo bastante delimitado. Para tal finalidade, inclusive, foi necessário afastar o atributo "confiança", antes descrito como premissa, sob pena de não se poder falar em modelo aproveitável em ambientes ainda não tangidos pela cultura de cooperação informal. 
As soluções e propostas encontradas neste trabalho, à toda evidência não são válidas nos ordenamentos jurídicos filiados ao sistema da common law, salvo em alguns pontos específicos como a arbitragem, entretanto, encontram fácil adaptação nos ordenamentos filiados ao sistema romano-germânico, que mutatis mutandi, apresentam os mesmos institutos jurídicos com pequenas variações. 


\section{Referências Bibliográficas}

\section{Bibliografia Consultada}

ALMEIDA, A P. (1998a) Manual das Sociedades Comerciais. São Paulo, Saraiva, p. $39 / 145$.

ALMEIDA, A P. (1998b) Teoria e Prática dos Títulos de Crédito. São Paulo, Saraiva, p.46/51.

BAPTISTA, L.O. (1996). Dos Contratos Internacionais. Uma Visão Teórica E Prática . São Paulo, Saraiva.

BEVILÁQUA, C. (1956). Código Civil dos Estados Unidos do Brasil Comentado. São Paulo, Editora Revista dos Tribunais.

BREMER, C. F. (2000). Empresas Virtuais. Disciplina oferecida no Curso de Pós Graduação do Departamento de Engenharia de Produção da EESC.

BREMER, C. F.; CORREA, G. (1995). Aplicação Da Metodologia De Integração Da Manufatura Em Empresas Nascentes De Alta Tecnologia. In: Congresso Brasileiro De Engenharia Mecânica - Cobem, Ufmg, Belo Horizonte.

BREMER, C. F.; EVERSHEIM, W.; WALZ, M.; MOLINA, A. (1999). Global Virtual

Business: A Systematic Approach Fpr Exploiting Business Opportunities In Dynamic Markets. International Journal Of Agile Manufacturing, V.2, N.1, P.1-11, Jan.-Fev.

BULGARELLI, W. (1986).Contratos Mercantis. São Paulo, Saraiva.

BYRNE, J.A. (1993). The Virtual Corporation. Business Week, P.98-103, Fev.

CARMONA, C.A. (1997) A Nova Lei de Arbitragem. Revista Jurídica Consulex, p.46, Set.

CAMARINHA-MATOS, L. M.; AFSARMANESH, H. (1999). The Virtual Enterprise Concept. Cap. 1. P. 5-29.

CHIAVENATO, I. (1993) Teoria Geral da Administração, São Paulo: Makron Books, (cap. 14)

COELHO, F.U. (1998). Curso De Direito Comercial. Vol. 1, São Paulo, Saraiva,.

DAVID, R. (1978). Os grandes sistemas do direito contemporâneo: direito comparado.

Tradução Hermínio A. de Carvalho. 2 ed. Lisboa : Meridiano. 
DAVIDOW, W.H.; MALONE, M.S. (1993). Das Virtuelle Unternehmen: Der Kunde Als Co-Produzent. Frankfurt, Campus Verlag.

DINIZ, M.H. (1996) Tratado Teórico E Prático Dos Contratos.2ª Ed. São Paulo, Saraiva ,.

ELLENRIEDER, A.(1996). Alianças Estratégicas E Parcerias.

Http://Www.Boucinhas.Com.Br/Forum/Par_Est.Htm.

EVERSHEIM, W. (1997) Informationstechnologie Als Wegbereiter Für Den

Wertschöpfungs-Verbund. Seminar Virtuelle Fabrik, Universität St. Gallen, Vortrag 12, Fev.

EVERSHEIM, W.; KLOCKE, F.; PFEIFER, T.; WECK, M. (1996a) Awk Wettbewerbsfaktor Produktionstechnik: Aachener Perspektiven. Düsseldorf, Vdi-Verlag.

FRESE, E. (1993) Grundlagen Der Organisation: Konzepte - Prinzipien - Strukturen. Wiesbaden, Gabler Verlag.

FURTADO, P.(1997). Arbitragem - Aspectos Jurídicos e Econômicos, Revista Jurídica Consulex, N.4.

GOLDMAN, S.; NAGEL, R.; PREISS, K. (1995) Agile Competitors - Concorrência E Organizações Virtuais. São Paulo, Editora Érica.

GOMES, O. (1979) Contratos, Rio de Janeiro, Forense.

GORANSON, T. (1995) Agile Virtual Enterprise - Best Agile Practice Reference Base. Http://Www.Agilityforum.Org/Ex_Proj/Mave/Bookfile.Htm

GOVINDARAJAN; S.(1995). Gestão Estratégica De Custos. São Paulo, Campus.

GROOS, P. (1997) Wandel Der Arbeitswelt: Vom Angestellten Zum Portfolio-Worker. Seminar Virtuelle Fabrik, Universität St. Gallen, Vortrag 9, Fev.

HAMEL, G.; PRAHALAD, C. K. (1995). Strategy As Stretch And Leverage. Ieee Managemet Review, V.23, N.1, P.2-9.

HAMEL, G.; PRAHALAD, C.K. (1995) Competindo Pelo Futuro. Rio De Janeiro, Campus.

KHURANA, A. (1996) Understanding Contigencies For Lean Manufacturing: Steps

Towards Agile Manufacturring. Proceedings Of The Fifth National Agility Conference, Boston, Mar.

KOCIAN, C. (1997) Der Mittelstand In Aufbruch - Virtuelle Unternehmensverbünde Als Zukunftschance?. Universität Des Saarlandes, Abr. 
KOCIAN, C.; SCHEER, A. -W. (1996). KIESEL - Das Virtuelle Umweltkompetenzzentrum - Theorie Und Praxis Der Virtuellen Unternehmung, M\&C Management Sonderdruck.

LANGER, D.(1996). Partnering Offers New Opportunities For Corporate Growth. Leavy, B. (1996). Outsourcing Strategy And A Learning Dilemma. Production And Inventory Management Journal, Fourth Quarter, P. 50-54. Http://Www.Langerco.Com/Lect.Html.

LODI, J. B. (1988). Conselho de Administração. São Paulo, Pioneira, p. 121/143.

LOFTSPRING, P.D. (1997a). Alliancing: A Paradigm In Transition, Getting The Incentives Right, Part One: The Alliance Paradigm - An Overview. Http://Www.MosburgoilGas.Com/Vol2_No4/05-01_Strategic_Alliance_0797.Html

LOFTSPRING, P.D. (1997b). Alliancing: A Paradigm In Transition, Getting The Incentives Right, Part Two: Alliancing: A Paradigm In Transition... Http://Www.MosburgoilGas.Com/Vol2_No4/05-01_Strategic_Alliance_0797.Html

LOFTSPRING, P.D. (1997c). Alliancing: A Paradigm In Transition, Getting The Incentives Right, Part Three: Alliances Of The Future.. . Http://Www.MosburgoilGas.Com/Vol2_No6/05-01_Loftspring_Alliance_1197.Htm

LORANGE,P.; ROOS, J. (1996) Alianças Estratégicas: Formação, Implementação E Evolução, São Paulo, Atlas.

MAGAlHÃES, J.C.\& BAPTISTA, L.O. (1986) Arbitragem Comercial. Rio De Janeiro, Freitas Bastos,.

MARCAR(1997). Strategic Alliance Guidelines And Best Practices. Definition Of Strategic Alliances And The Alliace Process. . Http://Www.Marcar.Com/Alliance_Guide.Htm MARTINS, F. (1996)Contratos E Obrigações Comerciais. 14 ${ }^{\mathrm{a}}$ Ed. Rio De Janeiro, Forense.

MARTINS, I.V.S. (1993). Curso De Direito Tributário. $2^{\text {a }}$ Ed. Vol.2. Belém, Cejup, Centro De Extensão Universitária.

MENDONÇA, J.X.C.(1945). Tratado de Direito Commercial Brasileiro, Vol. I, $4{ }^{\text {a }}$ ed. Rio de Janeiro, Freitas Bastos, p. 59/61.

MERTENS, P. (1994). Virtuelle Unternehmen. Wirtschaftsinformatik, N.36 (2),P.169-172.

MONTEIRO, W.B (1978).Curso De Direito Civil. São Paulo, Saraiva , p.111

NADLER, D. A. \& TUSHMAN, M.L. in: NADLER, D. A. ; GERSTEIN, M. S. ; SHAWN, R.B. (1994). Arquitetura Organizacional, Rio de Janeiro; Campus.(Cap.2) 
NALINI, J. R.(1999). Ética Geral e Profissional, 2 ed. São Paulo, Editora Revista dos Tribunais.

OKSANA, A.; HÄRTLING, M. (1995). Virtuelle Unternehmen: Begrifsbildung und diskussion. Arbeitspapier der Reihe Informations- und Kommuni-kationssystem als Gestaltungselement Virtueller Unternehmen, n.3, p. 38.

ORGALIME, (1995) Konsortial-Vertrag, Leitfaden für die Investitionsgüter-Industrie, Frankfurt.

PAINTER, C. (1997) Developing Strategic Alliances.. Http://Www.Apci.Com/Gases /17852/E2b1.Html

PFOHL, H.-C. (1996) Logistiksysteme: Betriebswirtschaftliche Grundlagen. Heidelberg, Springer

PICOT, A.; Reichwald, R.; Wigand, R. (1997) Information, Organization And Management - Expanding Markets And Corporate Boundaries. London, John Wiley \& Sons

PRIBILLA, P.; REICHWALD, R.; GOECKE, R (1996) Telekommunikation In Management. Stuttgart, Schaffer Poeschel Verlag.

RAO, V. (1994) Ato Jurídico - Noção pressupostos, elementos essenciais e acidentais. O problema do conflito entre os elementos volitivos e a declaração.

REALE, M. (1976) Lições Preliminares De Direito. $3^{\text {a }}$ Ed. São Paulo, Saraiva.

REID, R. L.; ROGERS, K. J.; JOHNSON, M. E.; LILES, D. H. (1996). Engineering The

Virtual Enterprise. Institute Of Industrial Engineers, 5th Industrial Engineering Research Conference Proceedings, P. 485-490.

REQUIÃO, R. (1977) Curso De Direito Comercial, 8 ed., São Paulo, Saraiva, p. 240/244

RODRIGUES, S. (1998) Direito Civil. São Paulo, Saraiva, Vol. 1.

ROSENER, W. Vertrag für ein Aussenonsortium mit Federführer, III. 3. In: Münchener Vertragshandbuch, Band 2, hrsg. Von Schütze/Weipert, 4. Auflage, München 1997, p. 388-406.

SCHUH, G.; MILLARG, K.; GÖRANSSON, ̊̊ (1997). Virtuelle Fabrik: Neue Marktchancen Durch Dynamische Netzwerke, München, Carl Hanser Verlag.

SEVERINO, A. J. (1996) Metodologia do trabalho científico. São Paulo: Cortez, , 20 Ed.(pg. 121) 
SIEBER, P. (1997). Virtuelle Unternehmen: Eine Zusammenfassung. Workshop Virtualität Als Wettbewerbsfaktor, Universität Bern, Fev.

SILVA, D. P. (1978) Vocabulário Jurídico, 5ª ed. , Rio de Janeiro, Forense, p. 1220.

SOARES, G.F.S. (1999) Common Law - Introdução ao Direito nos EUA.

STRENGER,I. (1992) Contratos Internacionais Do Comércio. $2^{\mathrm{a}}$ Ed. São Paulo, Revista Dos Tribunais.

SCHUH et al. (1997)

TRADEWINDS (1997). Partnerships And Strategic Alliances. . Http://Www.TradewindsTv.Com/Program3/En0320.Html.

WIGAND, R. T. (1997). Enablers and Boudaries of na Emerging Organizational Form. Program in Information hanagement. //hsb.baylor.edu/ramsower/ais.ac.97/papers/wigand.htm.

YOSHINO, M. Y.; RANGAN, U. S. (1997) Alianças Estratégicas. São Paulo, Makron Books Do Brasil Editora Ltda.

ZAIRI, M. (1996). Competition: What Does It Mean?. Tqm Magazine, V.8, N.1, P. 54-59.

ZIMMERMANN, F.O. (1997) Structural And Managerial Aspects Of Virtual Enterprisesalmeida, A.P .Manual Das Sociedades Comerciais. 10 $10^{a}$ Edição. São Paulo, Saraiva, 1998. , Http://Www.Uni-Karlsruhe.De/ It-Vision/Vu-E-Teco.Htm. 


\section{Bibliografia Indicada}

ASBECK, O. W. (1990). Wirkungsvolle Zusammenarbeit Gleichberichtiger Partner. Die Arbeit Von Strategischen Allianzen. Das Beispiel Kolbenschimdt. Blick Durch Die Wirtschaft, V.7, Nov.

BOWONDER, B.; MIYAKE, T. (1997). R \& D And Business Strategy: Analysis Of :Practices At Canon. International Journal Of Technology Management, Special Issue, P. 833-852.

BROWNE, J.; SACKETT, P.; WORTMANN, J. (1995). Future Manufaturing Systems Towards The Extended Enterprise. Computer In Industry, Special Issue On Cim In The Extended Enterprise, V.25 N.3, P.235-254, Mar.

CHESTER, A. N. (1997). Business Culture And The Practice Of Technology Management. Inernational Journal Of Technology Management, V.13, N.2, P.120-132.

COHEN, W. M.; LEVINTHAL, D. A. (1990). Absorptive Capacity: A New Perspective On Learning And Innovation. Administrative Science Quaterly, V.35, P.128-152.

DREIFUS, S. B. (1992) Building Core Competences In A Global Company. The Economist Intelligence Unit, New York.

DRUCKER, P. (1994) Sociedade Pós Capitalista. Rio De Janeiro, Editora Campus.

EVERSHEIM, W.; BREMER, C. F.; KAMPMEYER, J. (1996b). Requirements For Virtual

Enterprises Management In Developing Countries. International Conference On Engineering And Technology Management, Vancouver, Canada, P.84-88.

FACHEUX, C. (1997). How Virtual Organizing Is Transforming Management Science. Communications Of The Acm, V.40, N.9, P. 50-55.

GOULD, P. (1997). What Is Agility?. Manufacturing Engineer, P.28-31, Fev.

GRANDORI, A.; SODA,G. (1995). Interfirm Networks: Antecedents, Mechanisms, And Forms. Organization Studies, Fev.

HAMEL, G.; DOZ, Y.; PRAHALAD, C. K. (1989). Collaborate With Your Competitors And Win. Harvard Business Review, P. 133-139, Jan.-Fev.

HAMEL,G.; HEENE, A. (1994) Competence Based Competition. Chichester, John Wiley \& Sons. 
HÄUSLER, J.; HOHN, H.-W.; LÜTZ, S. (1995). Contingencies Of Innovative Networks: A Case Of Successful Interfirm R\&D Collaboration. Ieee Management Review, V.23, N.1, P. 42-55.

HIRSCH, B. E.; THOBEN, K.-D.; HOHEISEL, J. (1998). Requirements Upon Human Competencies In Globally Distributed Manufacturing. Computers In Industry, V.36, P. 49-54.

KIM, W. C.; MAUBORGNE, R. (1999) Creating New Market Space. Harvard Business Review, P. 83-93, Jan.-Fev.

LEI, D. T. (1997). Competence-Building, Technology Fusion And Competitive Advantage: The Key Roles Of Organizational Learning And Strategic Alliances. International Journal Of Technology Management, V.14, N. 2-3-4, P.208-237.

MILLER, K. (1995). The Mittelstand Takes A Stand. Business Week, P.16-17, Abr.

MOLINA, A. G.; BREMER, C. F. (1997). Information Model To Represent The Core Competencies Of Virtual Industry Clusters. Rheinisch-Westfäliche Technische Hochschule - Werkzeugmaschinenlabor, Final Report.

MOWSHOWITZ (1997). Virtual Organization. Communications Of The Acm, V.40, N.9, P. 33-37.

MOWSHOWITZ, A. (1986). Social Dimensions Of Office Automation. In: Yovitis, M.C. (Hrsg.), Advances In Computers, N.25, P.335-404.

NIEWÖHNER, F. (1996) Small And Medium Enterprises And Cooperations. Aachen - São Carlos, 126p. Studienarbeit - Werkzeugmaschinenlabor Von Der Rheinsich-Westfäliche Technische Hochschule.

NILSSON, C.-H. (1997). Strategic Alliances, Trick Or Treat? The Case Of Scania. International Journal Of Production Economics, V.52, P. 147-160.

NÜTTGENS, M.(1995). Kooperationsmodelle Für Vernetzte Kmu-Strukturen. Institut Für Wirtschaftsinformatik-Heft, 8.

OLAVE, M. E. L. (1998) Uma Análise De Redes De Cooperação Das Pequenas E Médias Empresas Do Setor Das Telecomunicações. São Paulo. 149p. Dissertação (Mestrado) Escola Politécnica, Universidade De São Paulo.

OLIVEIRA, J.C. (1998)Código De Proteção E Defesa Do Consumidor (Comentado). Leme, Sp, Led,. 
ÖSTERLUND, J. (1997). Competence Management By Informatics In R \& D: The Corporate Level. In: Transactions On Engineering Management, V.44, N.2, P.135-145, Mai.

PICOT, A.; REICHWALD, R.; WIGAND, R. (1996) Die Grenzenlose Unternehmung. Weinheim, Gabler Verlag.

PORTER, M. (1985) Vantagem Competitiva - Criando E Sustentando Um Desempenho Superior. São Paulo, Campus.

PORTER, M. (1999) Clusters e Competitividade - H S M Management, n. 15- julho/agosto, p. 102.

POWELL, W. (1990). Neither Market Or Hierarchy Networks Forms Of Organization. Research In Organizational Behavior, V.12, P. 295-336.

REISS, M.; BECK, T. (1995). Kernkompetenzen In Virtuellen Unternehmen - Der Ideale Strategie-Struktur-Fit Für Wettbwerbsfähige Wertschöpfungssysteme ?. Universität Stuttgart.

REITHÖFER, W.; NÄGER, G. (1997). Bottom-Up Planning Approaches In Enterprise Modeling --The Need And The State Of The Art. Computers In Industry, V.33, P. 223235.

RIBAULT, M.; MARTINET, B.; LIBEDOIS, D. (1995) A Gestão Das Tecnologias. Coleção Gestão \& Inovação, Lisboa, Publicações Dom Quixote.

ROCKART, J.F.; SHORT, J.E. (1989). Information Technology In The 1990s: Managing Organizational Interdependence. Sloan Management Review, V.30, N. 2, P. 7-17.

SEBRAE (1993) Indicadores De Competitividade Para Micro E Pequenas Empresas Industriais No Brasil. Brasília, Editora Sebrae.

SEBRAE (1998) Indicadores Da Mortalidade Das Mpes Paulistas - Relatório Parcial Para A Região Metropolitana De São Paulo. São Paulo.

SHI, Y.; GREGORY, M. (1998). International Manufacturing Networks - To Develop Global Competitive Capabilities. Journal Of Operations Management, V.16, P. 195-214.

TEERHAG, O.; DRESSE, S.; KÖLSCHEID, W.; NIEDER, A. (1996) Model For Transforming, Identifying And Optimizing Core Processes (Motion). RheinischWestfäliche Technische Hochschule - Werkzeugmaschinenlabor, Final Report. 
WILDEMAN, L. (1998). Alliances And Networks: The Next Generation. International Journal Of Tecnology Management, V.15, N.1-2, P. 96-108.

WRIGHT, D. T.; BURNS, N. D. (1997) Cellular Green-Teams In Global Network Organizations. International Journal Of Production Economics, V.52, P. 291-303. 


\section{Anexos}

No anexo 1, encontra-se o modelo de contrato de cluster em aplicação na VIRTEC. 